\title{
Human Rights, Populism, and the Political Economy of the World
}

\author{
Bonadiman, Luca
}

2020

Bonadiman , L \& Soirila , U 2020 , ' Human Rights, Populism, and the Political Economy of the World ' , Nordic journal of human rights , vol. 37 , no. 4 , pp. 301-328 . https://doi.org/10.1080/18918131.2020.17

http://hdl.handle.net/10138/336307

https://doi.org/10.1080/18918131.2020.1741321

unspecified

acceptedVersion

Downloaded from Helda, University of Helsinki institutional repository.

This is an electronic reprint of the original article.

This reprint may differ from the original in pagination and typographic detail.

Please cite the original version. 


\section{Nordic Journal of Human Rights Human Rights, Populism, and the Political Economy of the World --Manuscript Draft--}

\begin{tabular}{|c|c|}
\hline Full Title: & Human Rights, Populism, and the Political Economy of the World \\
\hline Article Type: & Original Article \\
\hline Keywords: & $\begin{array}{l}\text { Human rights; inequality; Philip Alston; populism; social and economic rights, } \\
\text { solidarity }\end{array}$ \\
\hline
\end{tabular}


Human Rights, Populism, and the Political Economy of the World

Luca Bonadiman

Institute for Global Law and Policy, Harvard Law School, Cambridge (MA), United States of America

1545 Massachusetts Ave, Langdell 175H

02138, Cambridge (MA)

lbonadiman@law.harvard.edu

Ukri Soirila

Faculty of Law, University of Helsinki, Helsinki, Finland

Yliopistonkatu, 3

FI-00014, Helsinki

ukri.soirila@helsinki.fi 


\title{
HUMAN RIGHTS, POPULISM, AND THE POLITICAL ECONOMY OF THE WORLD
}

\begin{abstract}
The commonly shared sentiment that human rights have reached a crisis in the form of a populist backlash has produced a vibrant discussion on the causes of and solutions to the crisis. This article seeks to contribute to that discussion by engaging with Philip Alston's important and influential essay on the topic, and in particular with his project of tackling material inequality. In so doing, the article makes two main points. First, it argues that the populism is most of all a form or a tactic, whereas the true antagonistic opponent of human rights might be the nationalist substance of populism. Secondly, the article agrees with Alston that a key reason for the populist backlash is material inequality, but challenges his view that the solution to the problem is to double down on 'familiar strategies', with the addition of providing social and economic rights a more prominent position within the human rights project. By contrast, the article suggests that a radical renewal of the human rights movement is called for - one accompanied by a more elaborate diagnosis of how human rights have been linked to inequalities and how they can engage with the structures and actors producing those inequalities. Trying to understand why human rights have lost ground to nationalism, the article suggests that a first step towards such more radical and dynamic human rights might be to unearth the now largely forgotten concept of solidarity, which once played a key part in the motto 'liberty, equality, fraternity'.
\end{abstract}

Keywords: human rights, inequality, Philip Alston, populism, social and economic rights, solidarity

\section{Introduction}

A crisis is often an opportunity for development or transformation. ${ }^{1}$ Such could be the case also for human rights - intended both as project and as discipline - which many see challenged the a so-called 'populist backlash'. Indeed, the populist challenge has produced a vibrant discussion regarding the future of human rights and the accomplishments and

\footnotetext{
1 The notion of 'crisis' would deserve a much longer discussion, as it can acquire significantly diverse meanings. For a brilliant conceptual analysis, see: Koselleck, R., 'Crisis', Journal of the History of Ideas, 67:2 (2006), $357-400$.
} 
shortcomings of what this article refers to as the 'human rights movement' 2 - a contested term which is used here to refer in particular to a wide range of mainstream, global human rights actors, including the best known (often Western) human NGOs, experts, scholars, and institutions; but mostly excluding more localized and grassroots forms of human rights activism.

One of the most important aspects of this discussion has been its increasing focus on issue of material inequalities, which is commonly seen as one of the root causes of the populist backlash. As critics have asked, is it not puzzling that the 'age of rights' 3 has coincided with a sharp increase in inequalities both between and within countries? ${ }^{4}$ How has the 'age of rights' become an 'age of inequalities' ${ }^{5}$ Is this just a coincidence or do human rights play a part in the political economy of the world? ${ }^{6}$

This article seeks to contribute to the discussion on the populist backlash, and in particular to the issue of human rights and inequality, by engaging with Philip Alston's insightful and influential essay on the topic. ${ }^{7}$ In seeking to galvanize human rights proponents against looming loss of faith, Alston touches on several pertinent issues regarding the crisis of human rights, one of which is of particular interest for the present article. This is his suggestion of tackling the questions of inequalities with increased focus on social and economic rights while doubling down on the familiar human rights strategies of recognition, institutions and accountability. ${ }^{8}$ Although we agree with Alston that increased

\footnotetext{
2 On the difficulty of using the term, see Alston, P., 'Reply to Dudai and Nagaraj', Journal of Human Rights Practice, 9 (2017), 25-28, pp. 25-26. On the history of the human rights movement, see Neier, A. The International Human Rights Movement: A History, Princeton University Press, 2012. Tracing the history further into the past, see Iriye, A., Goedde, P., \& Hitchcock, W., The Human Rights Revolution: An International History, Oxford University Press, 2012.

${ }^{3}$ The expression 'age of rights' has been notably coined by Henkin, L., The Age of Rights, Columbia University Press, 1990; for a similar account from the field of political theory, Bobbio, N., The Age of Rights, Polity Press, 1996 (also offering a periodization of human rights).

${ }^{4}$ For a recent, influential analysis on the interconnection, see: Moyn, S., Not Enough: Human Rights in an Unequal World, The Belknap Press of Harvard University Press, 2018.

${ }^{5}$ See, Milanović, B., Global Inequality: A New Approach for the Age of Globalization, The Belknap Press of Harvard University Press, 2016. For a more extensive and equally notorious analysis over a much longer timeframe, Piketty, T., Capital in the Twenty-First Century, Harvard University Press, 2014 (making the point that a major cause of inequalities is the differential between the return rate on capital and on labour).

6 See, Kinley, D., Civilizing Globalization: Human Rights and the Global Economy, Cambridge University Press, 2009; Whyte, J., The Morals of the Market: Human Rights and the Rise of Neoliberalism, Verso, 2019.

7 Alston, P., 'The Populist Challenge to Human Rights', Journal of Human Rights Practice, 9 (2017), 1-15.

${ }^{8}$ Ibid., p. 9.
} 
focus on social and economic rights is needed, we dispute that doubling down on the existing project is the best path forward. By contrast, in arguing that the 'crisis' of human rights might be less about populism than its entanglement or complicity with an unequal distribution of opportunities and resources around the world, we suggest that defending human rights might require a deeper and more granular understanding of how and to what extent human rights have been 'part of the problem'. 9

The article is comprised of four further sections. Section 2 briefly outlines Alston's main arguments and the responses it has attracted. The next two sections engage with two of Alston's arguments in more detail. Section 3 contends that today's main challenge for the human rights and the movement supporting them is less about pushing back on populism and the nationalist agendas they support than to focus on structural and distributional problems. Section 4 takes on Alston's aforementioned plan of doubling down on the existing human rights project, albeit with added focus on social and economic rights, by pointing out two key challenges in this regard: the incapacity of current conceptions of human rights to address some root causes of inequality, and their possible complicity to other such causes. Section Five argues that every 'crisis' is also an opportunity. In so doing, it suggests that a path forward for the human rights movement could be provided by unearthing the forgotten concept of solidarity and thus drawing from a now marginalized but more radical tradition of human rights thinking.

\section{Introduction}

In a recent article, Philip Alston confronts the current backlash on human rights, sketching out a possible path forward. ${ }^{10}$ Alston's contribution is important not solely because of the substantive insights he provides, but also because of his role of leadership within the human rights movement and regime. For Alston has an incredible track record: he is one of the most - if not the most - renown international human rights scholars, a prominent supporter and maker of the human rights regime, who has indeed held several prestigious appointments

\footnotetext{
9 The choice of words is inspired by Kennedy, D., 'International Human Rights Movement: Part of the Problem?', Harvard Human Rights Journal, 15 (2002), 101-125.

10 Alston, 'The Populist Challenge', pp. 4-7. See also, Alston, P., 'Human Rights Under Siege', International Journal on Human Rights, 14:25 (2017), 267-272.
} 
at the United Nations (UN), including two mandates as UN Special Rapporteur. ${ }^{11}$ Writing from the perspective of both an academic and as Special Rapporteur, his views bear considerable weight within the human rights movement and regime. Therefore, Alston's take on the situation is paradigmatic for a much broader range of scholars, professionals, and activists. We thus believe that his view demands a closer scrutiny.

Alston identifies five key challenges in the era of populist backlash, which entail that human rights proponents need to rethink many of their assumptions, re-evaluate their strategies, and broaden their outreach' - albeit 'without giving up on the basic principles' of the movement. ${ }^{12}$ The first challenge is the populist threat to democracy and, in particular, the growing willingness to sacrifice individual and collective freedoms at the altar of security. The second challenge is about the shrinking space for civil society, which is not only diminishing rapidly, but has already been entirely closed in many parts of the world. The third challenge is to find ways to address the issues of inequality and exclusion more effectively. The fourth challenge concerns the undermining of the international rule of law, especially with regard to the use of force vis-a-vis the marginalisation of international humanitarian law. Finally, the fifth challenge regards the fragility of international institutions, many of which - included but not limited to the International Criminal Court, the Human Rights Committee, the European Court of Human Rights, and the InterAmerican Court of Human Rights - have come under immense pressure due to budget cuts, the withdrawing of some members, or the unresponsiveness of others when it comes to planned 'reforms'. ${ }^{13}$

In response to such challenges, Alston suggests five strategies for addressing the perceived crisis. First, the human rights movement ought to develop better synergies between international and local human rights activism. Secondly, the human rights movement should include economic and social rights as important and authentic part of the overall human rights agenda. A third point is to broaden the outreach to identify new actors for cooperation, including corporations. Fourth, Alston advocates for new and more persuasive

\footnotetext{
11 Philip Alston was Special Rapporteur on Extrajudicial, Summary or Arbitrary Executions between 20042010; and he has held the office of UN Special Rapporteur on Extreme Poverty and Human Rights since 2014.

12 Alston, 'The Populist Challenge', p. 2.

${ }^{13}$ Ibid. pp. 4-8.
} 
communication strategies to more effectively engage both states and general public: instead of limiting its role to denouncing violations, the human rights movement could put forth less absolute arguments in order to structure a more prolific dialogue. Finally, Alston questions the benefits and scope of some critical scholarship, calling for a greater sense of responsibility on the part of human rights scholars. ${ }^{14}$

Alston's article has sparked a discussion which the present article also seeks to contribute to. For example, Vijay Nagaraj reflects on Alston's arguments through his experience with human rights protection in Sri Lanka. Nagaraj questions whether human rights have become too much of a language of 'law and other mechanisms of top-down authorization'; whether such embracement of procedures has brought advocates to lose their ability to speak of the idea of human rights 'as deriving from a deeper place, from a sense of relational ethics, love, compassion and solidarity'. ${ }^{15}$ Notably, Nagaraj acknowledges that human rights advocates in Sri Lanka have more or less ignored issues of economic harms and distributive injustices, many prominent activists believing that the human rights movement should focus on civil and political rights instead. This, Nagaraj seems to hint, could be due to the fact that the financial support for most human rights work in the country comes 'from the United States Agency for International Development (USAID) that is channelled through large for-profit contractors like Tetra Tech, Chemonics and others' for whom 'human rights is really just one more business'. ${ }^{16}$

In another response, Ron Dudai invites scholars to pay greater attention to the possible root causes of the populist backlash. For example, too little consideration is given to internal disillusionment, even though many of those who are 'ideologically aligned' with human rights values have grown increasingly frustrated with the inability of human rights institutions to 'deliver the goods' ${ }^{17}$ At the same time, the constant attempt to fit human rights into other frameworks, such as development or climate change, has also caused their

\footnotetext{
14 Ibid. pp. 8-13.

${ }^{15}$ Nagaraj, V.K., 'Human Rights and Populism: Some More Questions in Response to Philip Alston', Journal of Human Rights Practice, 9 (2017), 22-24. p.24

16 Ibid. 23.

${ }_{17}$ Dudai, R., 'Human Rights in the Populist Era: Mourn then (Re)Organize', Journal of Human Rights Practice, 9 (2017), 16-21, p.17.
} 
inflation and dilution. The lack of coherence might have made it easier for conservative and populist movements to hijack human rights language and causes. Not all problems are 'cultural' though. For instance, Dudai notes how new technologies have allowed almost anyone to document or claim possible human rights abuses, thus eroding the traditional role of human rights organizations. ${ }^{18}$ To confront these challenges, Dudai suggests that human rights organizations should rethinking the meaning of human rights activism tout court. In so doing, Dudai notes the difference between diplomatic forums such as Geneva and local activism, and argues that there is need to reconnect human rights with grassroots social movement and struggles so that human rights are not deployed in abstract discussions but to campaign against very concrete injustices. The rethink of the human rights platform and strategy ought to be particularly radical when it comes to economic and social rights; for Dudai, the time may have come to take a stronger stance against 'free markets' in favour of more effective forms of redistribution from the rich to the poor. ${ }^{19}$

Nagaraj and Dudai expose the two areas in which we believe Alston's intervention is perhaps incomplete. First, we agree with Dudai on the need for 'a more elaborate diagnosis' of the reasons of the 'current crisis' of human rights, ${ }^{20}$ for the polemical contention with populism might prove misleading. ${ }^{21}$ Secondly, we share with Nagaraj the sense that the bias and limits of the human rights regime and activism when it comes to economic and social rights runs deep, making Alston's envisioned solution potentially ineffective or at least insufficient.

Alston acknowledges that populism has been driven, at least in part, by legitimate sentiments for worsening economic conditions and rising inequality. He laments how mainstream human rights advocacy has addressed 'economic and social rights issues in a tokenistic manner at best, and the issue of inequality almost not at all', ${ }^{22}$ causing a loss of

\footnotetext{
18 Ibid. 17-18. On the role of technology in human rights documentation, see also Gregory, S., 'Cameras Everywhere Revisited: How Digital Technologies and Social Media Aid and Inhibit Human Rights Documentation and Advocacy', Journal of Human Rights Practice, 11 (2019), 373-392.

${ }^{19}$ Dudai, 'Human Rights in the Populist Era', p. 19.

${ }^{20}$ Ibid. p. 17.

21 Also addressed by Koskenniemi, M., 'Alston Rocking the Human Rights Boat: Reflections by a Fellow Passenger' (forthcoming).

${ }^{22}$ Alston, 'The Populist Challenge', p. 6. See also UN Human Rights Council (2015), Report of the Special Rapporteur on extreme poverty and human rights, Philip Alston. A/HRC/29/31.
} 
faith in human rights. Indeed, many now feel 'they have no stake in the human rights enterprise' ${ }^{23}$ To counter the populist backlash, human rights actors must therefore give economic and social rights a more central role in the human rights agenda so as to address the concerns 'of those who feel badly done by as a result of what we loosely call globalization-driven economic change'24. As Alston points out, this means that 'human rights proponents need to start looking at budgets, at tax policy, and at fiscal policies in general' - that is to say, all those issues that they have long tried to avoid. ${ }^{25}$

However, Alston's formula for harnessing human rights to tackle inequalities is less radical than it might sound. What is not needed, he warns, 'is to move the focus to the blight of poverty $(. .$.$) or to the need for more resources for development'. For Alston fears that when$ 'the rights are conflated or confused with development, or poverty alleviation', the campaign starts to seem 'huge and overwhelming', thus further alienating states afraid of burdening costs. ${ }^{26}$ Instead, Alston suggests that the solution is to follow an existing and familiar path, that is, 'to follow the recipe that we have developed for civil and political rights promotion' in order to advance social and economic rights as well. ${ }^{27}$ Such 'recipe' is about recognition, institutionalisation, and accountability:

'We need to (...) start with legislative and other forms of recognition of a right (...). Next we need to build up specialized institutions which are going to promote the right in ways that are meaningful in that society. And finally, we need to build up accountability mechanisms'.28

As Alston puts it, 'in terms of these essential elements of recognition, institutionalisation, and accountability, economic and social rights are no different' from civil and political rights' ${ }^{29}$ Hence, it appears to us that Alston is advocating for doubling down on what has been the key program and strategy of the human rights movement since the 1970s.

\footnotetext{
${ }^{23}$ Alston, 'The Populist Challenge', p. 6

24 Ibid..

${ }^{25} \mathrm{Ibid}$. p. 10.

${ }^{26}$ Alston, 'The Populist Challenge', p. 9

27 Ibid.

${ }^{28}$ Ibid.

${ }^{29}$ Ibid.
} 
Alston is not alone in this 'doubling down' approach. In other recent contributions to the Journal of Human Rights and Practice, different scholars ultimately echo the very same strategy of doubling down. For example, Paul Gready defends the importance of human rights work even when success is uncertain and responses hostile because it is the right thing to do and because moral acts 'leave a trace, sow a seed'. 30 The challenge, as he sees it, lies mainly in communication: the human rights movement ought to spend more time and energy on being persuasive, on learning how to frame arguments, how to embed facts in compelling narratives about the future of society, and on rethinking solidarities without and within. ${ }^{31}$

In a different article, Mark Heywood also suggests that the way forward in promoting economic and social rights is to double down on the existing human rights platform. Heywood starts from a more drastic position than Alston, writing that the realization of socioeconomic rights under neoliberal forms of capitalist economy is perhaps impossible. He thus invites human rights scholars and advocates to show greater courage and willingness to address the question of who has control, who wields power. ${ }^{32}$ Furthermore, Heywood concedes to critics that human rights may have at times 'looked like a handmaiden to neoliberalism', for the forms of power and interest at play in capitalism found they have 'a self-interest in advancing human rights frameworks' ${ }^{33}$

While Heywood's analysis is perhaps more radical than Alston's, his solutions are nonetheless remarkably similar. For Heywood provides a powerful defence of human rights, pointing out that they have 'achieved significant pro-poor reform in the last two decades', and that surrendering the framework would 'leave us much weaker in our fight for equality.' ${ }^{34}$ Indeed, if the human rights covenants have produced disappointing results, this is so, according to Heywood, primarily because the United Nations Treaty Bodies they

\footnotetext{
${ }^{30}$ Gready, P., 'Reflections on a Human Rights Decade, Near and Far', Journal of Human Rights Practice, 11 (2019), 422-437, p. 423. Gready draws from Shulman, D., 'On the Goodness of Despair', Journal of Human Rights Practice 6:3, (2014), 503-510.

${ }^{31}$ Gready. 'Reflections on a Human Rights Decade', 431-435.

32 Heywood, M., 'South Africa's Journey from Socialism to Human Rights: The True Confessions of an Errant Socialist', Journal of Human Rights Practice, 11 (2019), 305-323, p. 318

${ }^{33}$ Ibid. 317.

34 Ibid.
} 
produced 'have not yet been effectively utilized by civil society to demand their enforcement as global standards'. ${ }^{35}$ Therefore, Heywood believes in doubling down on the existing human rights project and institutions, too.

The general consensus for doubling down on the existing human rights platform is married with a twofold appeal: human rights activism ought to find better ways of communicating and also be more pragmatic. In practice, this approach translates into reviving the legal potential of the United Nations' International Convention on Economic, Social, and Cultural Rights (ICESCR). Indeed, both Alston's and Heywood's arguments point to Olivier de Schutter's work against regressive socio-economic measures. Indeed, de Schutter notes that most states have already ratified the ICESCR, but argues that they enjoy excessive discretion in implementing it. The problem, as he sees it, is one of accountability and therefore justiciability of economic and social rights. To counter such problem, de Schutter claims that both regressive policies and non-implementation amount to violations of the Convention. ${ }^{36}$ As economic and social rights are already recognised and enshrined within a legally binding convention, the human rights movement should focus on greater institutionalisation and accountability, thus becoming more vigilant and capable of evaluating economic and fiscal policies to ensure the state compliance to its core obligations.

There is great merit to de Schutter's approach. There are some relative risks, too. For example, expanding the 'recognition, institutionalisation, and accountability' strategy to economic and social rights in the way Alston, Heywood, and de Schutter envision is likely to also double down on that culture of expertise that has come under scrutiny and has been the target of populist attacks. For holding states accountable on the economic and social obligations can only translate in greater demand for new types of international expertise. The struggle thus becomes one between the alleged moral primacy of human rights and technical neutrality of international bureaucracies versus the 'politics' of populist movements. The implied danger is therefore that of fuelling rather than defusing populism. This perhaps superficial example about expertise suggests that Alston's grievance against

\footnotetext{
35 Ibid. 318.

${ }^{36}$ De Schutter, O., The Rights-Based Welfare State: Public Budgets and Economic and Social Rights, Friedrich Ebert Stiftung, 2018, p. 3, 9.
} 
'destructive and irresponsible' critical scholarship is perhaps short-sighted. ${ }^{37}$ As Martti Koskenniemi puts it, 'taking a break from criticism of human rights (...) is not likely to strengthen them' either, for the present problems of the movement are less a consequence of critical scholarship and more 'by the intellectual autism of human rights culture' ${ }^{38}$

The present article indeed responds to the calls of both Dudai and Koskenniemi, for 'more awareness is needed about what the "backlash" stands for and what might be needed in response to it'. ${ }^{39} \mathrm{~A}$ more attentive analysis of the current threat means identifying the actual problems and challenges so to provide more effective strategies. We want to question whether, if 'the challenges ... are fundamentally different', the most effective strategy is to really double down on the existing recipe. For instance, such view avoids confronting uncomfortable demands on how human rights may have contributed to the existing discontent. Doubling down on the human rights program without first understanding its entanglement with the world could prove both ideological and risky, as it might turn into a doubling down on errors and regrettable mistakes. Therefore, our intent is not that of contesting Alston, but rather that of broadening the scope and terms of the current debate about and around the threats of populism and the ability of human rights to engage with issues of inequalities.

\section{Human Rights and Populism}

Although the main focus of this article is on Alston's call to double down on the existing human rights project to address material inequality, we agree with Dudai that addressing that problem requires some more conceptual clarity regarding the so-called crisis of human rights, for such clarity may help assess the steps that are needed to reorient the human rights movement. In seeking to provide more elaborate conceptual lenses through which to view the 'crisis', we wish to question whether presenting human rights and populism as antagonistic opposites to each other is the best possible path forward.

\footnotetext{
${ }^{37}$ Dudai, “'Human Rights in the Populist Era', pp.19-20. See also, Sharp D.N., 'Through a Glass, Darkly: Three Important Conversations for Human Rights Professionals', Journal of Human Rights Practice, 11 (2019), 296-304, pp. 299-300.

${ }^{38}$ Koskenniemi, 'Alston Rocking the Human Rights Boat'.

${ }^{39}$ Ibid.
} 
As Alston writes, echoing many similar voices, 'the populist agenda that has made such dramatic inroads recently is (...) explicitly antagonistic to all or much of the human rights agenda' ${ }^{40}$ But although Alston has good reasons for this statement, this section argues that viewing populism as the antagonist of human rights might ultimately prove misleading. ${ }^{41}$ In so doing, the section makes two points: first, populism ought to be understood not as an agenda but as a tactic or a tool; and secondly, the actual challenge to human rights is thus not populism as such, but how nationalist uses of populist tactics are eroding the democratic fabric of liberal states on the two shores of the North Atlantic and beyond.

As we argue, shifting the focus on nationalism might help reorient the human rights movement. For much like populism, nationalism is also far from a monolithic entity. At least in Western states, nationalist populism has taken two very damaging forms. Firstly, populist rhetoric has been used to exclude various 'others' from asylum seekers to minorities. Secondly, and importantly for this article, it has also been used to justify drastic economic projects, such as the kinds of tax 'reforms', which have turned out to be mostly tax cuts that benefit large corporations and shareholders. ${ }^{42}$ However, in addition to these destructive forms, there is also a positive element to nationalism - one which perhaps has appealed to the public but which has been entirely ignored in the contemporary populist practices. This element is solidarity, which is the forgotten term from the revolutionary triad 'freedom, equality, solidarity'. As we argue, returning solidarity to its place of honour may help reprogram the human rights movement and gain back some ground that it has lost to nationalist populism.

\section{3..1 On Populism...}

\footnotetext{
40 Ibid. p. 1.

41 This antagonism echoes Oakeshott, M., The Politics of Faith and the Politics of Scepticism, Yale University Press, 1996 (arguing that democracy is a dialectic between two forces, faith and scepticism). Populist movements would embody the politics of faith, whereas human rights and their resistance would embrace the politics of scepticism.

42 See, for the United States, the Tax Cut and Jobs Act ('An Act to provide for reconciliation pursuant to titles II and $\mathrm{V}$ of the concurrent resolution on the budget for fiscal year 2018'), Public Law No. 115-97, 2017. Read further, August, J.D., 'Tax Cuts and Jobs Act of 2017 Introduces Major Reforms to the International Taxation of U.S. Corporations', The Practical Tax Lawyer, 32:2 (2018), 43-54.
} 
One has to be careful when discussing populism - especially in the international context for there are so many modes of it, from conservative to progressive and right-wing to leftwing versions. ${ }^{43}$ Nevertheless, there are some elements that at least most versions have in common. Whether one intends it as ideology, discourse, or strategy, populism is about seizing power - most notably, state power. Populism does not have any substantive government program of its own because it is mostly a tactic to occupy the state via the formally regular course of democratic processes. ${ }^{44}$ Indeed, populist leaders run in the general elections, often through the very party system they ultimately undermine. They seduce voters with bombastic rhetoric and the lure of untenable promises, the realisation of which is often made dependant on the preliminary defeat of some real or imaginary 'enemy', thus exacerbating divisions and conflicts in society. Once in government, many populist movements display remarkably authoritarian traits: in face of poor performances in delivering on any such promise, the frequent populist response is to blame some internal or external 'enemy'. ${ }^{45}$ This could be a foreign government allegedly interfering with internal affairs, some minority conspiring against the people and the state, or even the so-called 'deep state' 46 that supposedly hinders the otherwise effective action of the government with rules and procedures, thus offering additional momentum to push back on checks and balances. The rhetorical use of the more or less invisible enemies further allows populist leaders to assert a monopoly in speaking for 'the people'. ${ }^{47}$ Hence, populist leaders and movements can steer negative sentiments of a purported majority to seek an even stronger mandate through new elections, ultimately transforming the political life of a country into an endless electoral campaign. ${ }^{48}$

\footnotetext{
${ }^{43}$ For an overview of different theories and interpretations, Anselmi, M., Populism: An Introduction, Taylor and Francis, 2017.

${ }^{44}$ Populism has been also intended as 'political style' or 'performance', see, Moffitt, B., The Global Rise of Populism: Performance, Political Style, and Representation, Stanford University Press, 2016 (pointing to the role of technology as contributing to the success of populism. New digital platforms offer political leaders or representatives a way to communicate 'directly' with their supporters).

${ }^{45}$ This strategy is carefully described in Jünger, E., Der Waldgang, Klett-Cotta, 1986 (detailing the Nazi strategy of growing consensus while justifying failures by producing internal and external enemies).

${ }^{46}$ E.g., Santos, R., The Deep State, Greenhaven Publishing, 2018 (focusing on the military industry and apparatus). The deep state is largely regarded as one of the many 'conspiracy theories' of contemporary politics. It is a way to refer to unelected bureaucrats that use their authority and prerogatives to trump political decision making in order to advance personal agendas.

47 Müller, J.-W., What Is Populism?, University of Pennsylvania Press, 2016 (arguing that contemporary populism represents a cultural reaction to pluralism).

${ }^{48}$ A phenomenon that has become intrinsic to American democracy (see, Lexington, 'The Endless Campaign', The Economist, August 27th 2001), but has intensified and spread to other Western democracies.
} 
Taken this way, populism is a 'malady' of liberal democracies - a 'malady' primarily affecting the way some political groups organise and strategize to seize and retain state power. ${ }^{49}$ Therefore, this 'disease' affects multi-party democracies when existing political parties fail to renovate and grow distance from their voters, especially in times of economic crisis. Surfing the discontent and appealing on the perceived self-referentiality of political parties and state bureaucrats, populist leaders often win support from voters presenting themselves as statesmen ready to 'drain the swamp'. ${ }^{50}$ Indeed, another common feature of populist movements is to assert their moral primacy over other, allegedly corrupt, groups. However, once installed into office, populist leaders or movements display a preference for loyalty over competence (i.e., 'clientelism'), 51 the inclination towards forms of protectionism (to acquire and reward clients), an idiosyncratic understanding of security, and so forth, thus exacerbating those negative features they were meant to fight. Largely centred on the charismatic figure of a leader, populist movements tend to unsettle the traditional division of powers, often marginalising the legislative branch at the advantage of the executive.

What these considerations of common features of populist movements in the context of party politics exposes is that populism is most of all a tactic to gain power for seizing, retaining, concentrating, or eventually displacing institutional power - or eventually a tool to exercise power. Populism is therefore not so much a matter of substance, but of form. Indeed, although liberal by heart, the human rights movement, too, has on occasion adopted tactics that might be regarded as populist. One such examples is 'naming and shaming', a media pillory aimed at galvanising the sentiments of people to provide strength and legitimacy to a cause or campaign against a given practice or government. ${ }^{52} \mathrm{Naming}$ and shaming can steer strong emotions and it often results in an ideological 'war of trenches',

\footnotetext{
49 The idea of 'malady' is borrowed from Revelli, M., Populismo 2.0 (Populism 2.0), Einaudi, 2017.

50 The expression has become frequent under US President Donald Trump. Cf. inter alia, (pro), Douthat, R., 'Under Trump, the Swamp is Draining', The New York Times, December 1st, 2018; (contra), Olen, H., 'Trump Didn't Drain the Swamp. Supporters Are Starting to Notice', Washington Post, September 11 $11^{\text {th }}, 2018$.

${ }^{51}$ For an analysis of the widespread phenomenon, Stokes, S., Political Clientelism, Oxford University Press, 2011.

52 There is a vast literature both in favor and critical to the practice. For a broader account in the general practice of international relations, Friman, H., The Politics of Leverage in International Relations: Name, Shame, and Sanction, Palgrave Macmillan, 2015. On the limits of 'naming and shaming', Domínguez-Redondo, E., 'The Universal Periodic Review -- Is There Life Beyond Naming and Shaming in Human Rights Implementation?', New Zealand Law Review, 4 (2012), 673-721.
} 
that is: 'us versus them', 'victims versus perpetrators'. ${ }^{33}$ Similarly, human rights actors have enhanced their power through what could be regarded as populist tool: just like populist movements claim to speak for 'the people' as a whole, human rights claim to be acting in the name of 'humanity'. ${ }^{54}$

Speaking on behalf of either the people or humanity is a rhetorical populist tactic to enhance the sense of legitimacy, which often allows passing and/or disguising unpopular measures. ${ }^{55}$ For example, populist movements across the Western hemisphere have been successful in leveraging the discontent of the uncompensated losers of the increasingly sophisticated mechanisms of the political economy of the world. But the discontent of increasingly struggling workers, either unemployed or underpaid, has been used to promote protectionist trade tariffs at the advantage of national businesses. The frustration of a disappearing middle class has served to pass tax 'reforms', that is, tax cuts that benefitted mostly corporations and shareholders. ${ }^{56}$ In other words, populist tactics and tools are designed to serve particular agendas of those in power. In that, populism is certainly a very important red flag, an indicator that should no doubt attract the attention of the human rights movement. However, the risk is to engage with populism as if populist tactics were themselves the problem, as if the problem was one of form and/or procedures rather than actual substance. Instead, it is crucial to engage with the particular agenda that makes use of populist tactics. It seems plausible to suggest that the main agenda behind populist

\footnotetext{
53 Meister, R., 'Human Rights and the Politics of Victimhood', Ethics and International Affairs, 16:2 (2002), 91-108 (victimhood is functional to de-politicisation and it generates polarisation and resentment, thus paving the way for more conflictuality). More comprehensively, Simonsen, K., \& Kjærgård, J. (eds.), Discursive Framings of Human Rights: Negotiating Agency and Victimhood, Birkbeck Law Press, 2017.

${ }^{54}$ Inherent in this shared stance is the sense of moral superiority. Cf. Beitz, C., 'Human Rights as a Common Concern' American Political Science Review, 95:2 (2001), 269-282 (human rights as standard to evaluate governments and institutions). Beitz embraces the view for which human rights are de facto a global moral standard, which implicitly requires moving from an assumption of self-proclaimed moral superiority.

${ }_{55}$ Human rights and populist movements equally promise to vindicate the powerlessness of individuals, groups, and peoples against perceived injustices. Where they might differ, depending on the populist movement in question, is in identifying victims and injustices: for example, while human rights organization rightly side with the thousands of migrants crossing the Mediterranean Sea, the leader of the Italian populist movement Lega Nord presented Italian citizens as victims of migration.

56 See, for the United States, the Tax Cut and Jobs Act ('An Act to provide for reconciliation pursuant to titles II and V of the concurrent resolution on the budget for fiscal year 2018'), Public Law No. 115-97, 2017. Read further, August, J.D., 'Tax Cuts and Jobs Act of 2017 Introduces Major Reforms to the International Taxation of U.S. Corporations', The Practical Tax Lawyer, 32:2 (2018), 43-54.
} 
movements, on both the left and the right, is largely nationalist. Therefore, the challenge is less about populism as such than it is about nationalism.

\section{2... and on Nationalism}

The issue that human rights scholars and advocates have with the prevailing political atmosphere cannot be just about populism per se. Rather, it seems that the issue is the substance of most current populist movements, namely nationalism. Indeed, human rights seem to be more antagonistic to nationalism - or at least some "deviant" versions of it - than they are to the empty form of populism. Although human rights cannot avoid a certain degree of entanglement with nationalism, for example in promoting self-determination, much of the history and institutional development of contemporary human rights is intertwined with curbing the potential brutality of nationalism and the nation state. In other words, the tension arises when nationalist rhetoric and programs drift into authoritarianism, fuelling social resentment, xenophobia, or even persecution, as happens in the current environment where human rights are needed in their original function in protecting minorities that nationalist rhetoric villainises. ${ }^{57}$

Nationalism is hardly a homogenous phenomenon, however. Just like for populism, the range and variety of nationalist movements is broad, as it includes people situated along the whole political spectrum, from right to left. ${ }^{58}$ Mapping the whole spectrum of contemporary nationalist movements and agendas is beyond the scope of the present work. The aim of this part is to question how nationalist narratives have become more persuasive and appealing than human rights. One possible answer is that human rights do not offer effective enough answers to some of the anxieties and preoccupations people confront in their daily lives. Here we encounter an issue raised by Nagaraj and Dudai in their responses to Alston. For the human rights enterprise and movement have become highly

\footnotetext{
${ }^{57} \mathrm{~A}$ first wave of international human rights instruments after World War II was designed to ensure protection to national minorities against the abuses of governments. This was indeed the basis for the Convention on the Prevention and Punishment of the Crime of Genocide, United Nations, 1948. See, Vrdoljak, A.F., 'Human Rights and Genocide: The Work of Lauterpacht and Lemkin in Modern International Law', European Journal of International Law, Vol. 20:4 (2009), 1163-1194.

58 Similarly problematizing but also defending the usefulness of 'populism' as comprehensive analytical category, Brubaker, R., 'Why Populism?', Theory \& Society, 46:5 (2017), 357-385.
} 
bureaucratised and embedded within the very system they were supposed to contest. Human rights advocates have been used to speak truth to power, 59 but to the dismay of some activists, the human rights movement is today associated with those very elites that have become target of relentless criticism. Human rights are accused of being a regime of governance, an expert language translating vague political agendas into administrative goals, for which human rights experts negotiate, measure, and monitor the progresses of a sophisticated but self-referential international bureaucracy. ${ }^{60}$

The embeddedness is problematic for at least three reasons. First, the human rights movement has traditionally regarded itself as external to power, thus escaping accountability. Secondly, as the embeddedness is also cultural, there is a further bias in favour of measures or solutions that double down on the existing system and ideology. ${ }^{61}$ Finally, a position of embeddedness makes it more challenging to answer Dudai's call to explore and understand the root causes of a widening popular discontent, which ultimately results in growing support for nationalist platforms. The risk is for the human rights movement to engage into an ideological struggle to reaffirm the moral high ground of human rights against nationalist agendas. Although there is merit to that battle, it would fail to duly explore the reason why of nationalism, thus ignoring the anxieties and preoccupations of the very people the human rights movement aspires to speak for.

One reason why nationalisms might appeal to large parts of the population throughout the Western hemisphere is that they promise those forms of belonging and internal solidarity that globalisation has progressively eroded. In perhaps different ways, nationalist platforms

\footnotetext{
${ }^{59}$ Kennedy, Dark Side of Virtue, p. xvi. For a collection of stories on human rights activism, Kennedy, K., Adams, E., \& Richardson, N., Speak Truth to Power: Human Rights Defenders Who Are Changing Our World, Umbrage Editions, 2005.

${ }^{60}$ For a broader critique of international expertise (not limited to human rights), Easterly, W., The Tyranny of Experts: Economists, Dictators, and the Forgotten Rights of the Poor, Basic Books, 2013.

${ }^{61}$ From climate change to inequalities, the answers they often provide often consist of simply doubling down on existing systems. For example, at the 2019 Davos meeting, the envisioned solutions were 'more technology' and 'better education'. Long, H., '"The Aristocrats Are Out of Touch": Davos Elites Believe the Answer to Inequality is Upskilling', The Washington Post, January $26^{\text {th }}$, 2019. A summary of the main theme discussed at the forum is available on their website: www.weforum.org/focus/davos-2019 (last access, August $7^{\text {th }}$, 2019). UNICEF rephrased business 'non-solutions' as if they were the youth's actual demands. UNICEF, 'Young People to Davos: More Jobs, Better Education', Press Release, January 21st, 2019. Available at: www.unicef.org/press-releases/young-people-davos-leaders-more-jobs-better-education (last access, August $7^{\text {th }}$, 2019).
} 
on both the left and the right put particular stress on the idea of belonging, on identity. However, they also play identity against solidarity. Nationalist movements have confined and thus displaced the role of solidarity by linking it to the mere assistance to migrants and refugees. At the same time, governments have been outsourcing solidarity to private initiatives, causing civil society to become more and more dependent on philanthropy (i.e., philanthropic capitalism). ${ }^{62}$ Therefore, the identitarian argument of the nation is used today not to empower institutions and enhance forms of solidarity between members of the same community, 63 what is normally referred to as 'patriotism', 64 but instead to undo large portions of the welfare state and to enable a militarised form of territoriality to contrast alleged 'invasions' of undeserving migrants. That is, nationalist movements are deliberately attacking statehood and the entailed principle of solidarity. ${ }^{65}$

Nationalist movements are using populist struggles to take over the state with the apparent aim of undoing it. On the one hand, migration is mixed with terrorism in order to justify an increase in spending on military, police, and surveillance. On the other, migration also offers an argument to cut back on welfare provisions. At a deeper level, the objective appears that of dissolving the public sphere and its guarantees in order to unleash private forms of power - a remarkably regressive trend that goes to show that no social or political achievement should ever be taken for granted. The struggle is thus about the typology of the state: a minimalist and perhaps authoritarian 'nocturne guardian' or a welfarist state? Solidarity

\footnotetext{
62 See, e.g., Gaudiani, C., The Greater Good: How Philanthropy Drives the American Economy and Can Save Capitalism, Henry Holt, 2003; similarly, Bishop, M., \& Green, M., Philanthro-Capitalism: How the Rich Can Save the World, Bloomsbury Press, 2008 (arguing philanthropy is not charity but a form of social investment that can improve capitalism further). Ács, Z., Why Philanthropy Matters: How the Wealthy Give, and What It Means for Our Economic Well-Being, Princeton University Press, 2013 (suggesting the role of philanthropy is underestimated. It implicitly accepts that philanthropic capitalism is an American ideology increasingly spread on a global scale). 'Philanthropic capitalism' has been criticised for establishing forms of dominance, dependency, and pseudo-colonialism, Wilson, J., 'Fantasy Machine: Philanthrocapitalism as an Ideological Formation', Third World Quarterly, 35:7 (2014), 1144-1161; and for creating dysfunctional responses, especially when it comes to public health, inter alia, Clark, J. \& Mcgoey, L., 'The Black Box Warning on Philanthrocapitalism', The Lancet, 38:19 (2016), 2457-2459.

${ }^{63}$ Anderson, B., Imagined Communities: Reflections on the Origin and Spread of Nationalism, Verso, 2016. One interesting shift has been that of locating solidarity at the global level, antagonistically leveraging solidarity against nations. See, e.g., Goodman, J. \& James, P., Nationalism and Global Solidarities: Alternative Projections to Neoliberal Globalisation, Routledge, 2007.

${ }^{6}$ Cf. Murray, J., 'Nationalism, Patriotism, and New Subjects of Ideological Hegemony', Journal of Philosophy, 6:14 (2011), 16-30.

${ }^{65}$ On the synergies and tensions between contemporary nationalism and neoliberalism, Harmes, A.,'The Rise of Neoliberal Nationalism', Review of International Political Economy, 19:1 (2012), 59-86.
} 
(which is just another name for 'brotherhood') is the forgotten term from the revolutionary triad 'freedom, equality, solidarity'. Hence, the human rights movement could reappropriate the notion of solidarity to vindicate its original promise. To the extent nationalist movements are today undermining social welfare and replacing internal solidary with its boorish surrogate, that is, xenophobia, then human rights are better placed to promote a program that aims to re-establish solidarity relations between people within and beyond their national communities.

The widespread use of populist tactic to revive nationalist themes exposes an ongoing struggle to assert or consolidate dominance. The human rights movement needs to accept and embrace its position and role in a field of struggles - struggles that are political in nature, something that human rights proponents have been fairly reluctant to acknowledge. ${ }^{66}$ The human rights project does not consist of self-evident universal truths, but it rather pursues specific political interests that inevitably clash with those of others. Privileges of whatever nature are never given up without significant resistance and thus socio-political struggles. ${ }^{67}$ But many in the human rights movement hardly see themselves as actors seeking or leveraging power; 68 instead, they have adopted a position of 'watchdogs', 69 which ultimately betrays a certain degree of embeddedness within the very system they should challenge.

\section{Human Rights and the Political Economy of the World}

The previous section argued that a path forward for the human rights movement, and a possibility of gaining back lost ground from nationalist populist, may be to return the notion

\footnotetext{
${ }^{66}$ Kennedy, Dark Side of Virtue, p. xvi et passim.

${ }^{67}$ For an interesting account on inequalities throughout history, see, Scheidel, W., The Great Leveler: Violence and the History of Inequality from the Stone Age to the Twenty-First Century, Princeton University Press, 2017 (arguing that inequalities have historically decreased after wars, revolutions, dissolution of civilizations, and pandemics, which often occurred because of resistance to reforms for better wealth redistribution).

68 Koskenniemi, 'Alston Rocking the Human Rights Boat'

69 See, Risse, K.T., Ropp, C.S. \& Sikkink, K. (eds.), The Persistent Power of Human Rights: From Commitment to Compliance, Cambridge University Press, 2013 (the volume contains a number of interventions that track the transformation of human rights from grassroots advocacy to compliance and accountability).
} 
of solidarity to its position of prominence within the movement. We will return to this theme in the concluding section of the article. Before that, however, there is another point that has to be made to complete the picture. For although we argued above that the true antagonistic opponent of the human rights movement might be nationalism, rather than populism per se, it is worth noting that states and governments play today only partial functions within a broader political economy of the world. Prophets of globalisation have used this to suggest that nation states - and perhaps statehood as such - are doomed to fade. But while states have been progressively emptied of their political significance, they have not disappeared. They have been turned into security devices to protect private property, international investments, and other interests. ${ }^{70}$ For the postcolonial world has bypassed sovereign equality through a political economy that fundamentally perpetuates patterns of dominance.

In thinking about the role of potential of human rights in the context of this material reality, Alston is once again a useful interlocutor. As discussed in Section 2, Alston suggests that there could be a straightforward remedy to this situation, namely to more robustly include social and economic rights in the human rights programme. Alston thus invites human rights advocates to double down on a consolidated recipe: recognition, institutionalisation, and accountability. ${ }^{71}$ Alston's intervention is important because he is certainly correct to point out that social and economic rights have been for long marginalised for the most diverse reasons. ${ }^{72}$ Perhaps most importantly, many have been content with a mere promise of 'progressive realisation' that never quite materialised, social and economic rights having been labelled as more expensive and more difficult to both realise and enforce, compared to civil and political rights. ${ }^{73}$ Unsurprisingly, then, towards the end of the Millennium, a

\footnotetext{
70 Kennedy, D., 'Law and the Political Economy of the World', Leiden Journal of International Law, 26:1 (2013), 7-48.

71 This is also the view of Sikkink, K., The Justice Cascade: How Human Rights Prosecutions Are Changing World Politics, W.W. Norton \& Co., 2011. More recently, Sikkink, K., Evidence for Hope: Making Human Rights Work in the $21^{\text {st }}$ Century, Princeton University Press, 2017.

72 Their status as actual rights has been put under question. See, Cranston, M., "Human Rights: Real and Supposed", in Raphael, D.D. (ed.), Political Theory and the Rights of Man, Indiana University Press, 1967, pp. 4351; Cranston, M., 'Are There Any Human Rights?', Daedalus, 112:4 (1983), 1-17.

${ }^{73}$ On the attempts, failures, and successes of economic and social rights in reshaping the postcolonial world, Wills, J., Contesting World Order? Socioeconomic Rights and Global Justice Movements, Cambridge University Press, 2017 (the account lean more towards the future potential than effective success in the past).
} 
general frustration with the ineffectiveness of human rights to deliver on material needs brought countries from the global South to switch focus onto development. ${ }^{74}$

Where we disagree with Alston, however, is in his proposition that doubling down on the existing human rights project, but with extra attention on economic and social rights, is the best path forward. This is so for at least two reasons. First, human rights have become embedded in the political economy of the world: without sorting out their entanglement first, there is the risk of achieving the opposite end to the one allegedly sought. The second is the unwillingness or, more worryingly, inability on the part of the human rights movement to engage with the complexity and sophistication of the political economy of the world. The present Section thus discusses two problems: 'helplessness' and 'complicity'. While international lawyers have been paying greater attention to the significance of political economy and the role of international law in it, human rights have yet to seriously engage with this area. This Section aims to provide an initial input to what should possibly become a more widespread research agenda.

\subsection{The 'Helplessness' Problem}

In contemporary societies, matters of distribution and redistribution are incredibly complex; ${ }^{75}$ different narratives tend to reduce the problem to one or the other cause, often on the basis of some underlying ideological view. ${ }^{76}$ The increasing sophistication of the political economy of the world requires human rights to engage with technical aspects of law and their socio-economic impacts. But are human rights properly equipped for the task? Or to put it differently, is giving a more prominent role to social and economic rights, but

\footnotetext{
74 The relation between human rights and development has become a field of its own. As an introduction, inter alia, Langford, M., Sumner, A. \& Ely Yamin, A. (eds.), The Millennium Development Goals and Human Rights: Past, Present and Future, Cambridge University Press, 2013.

${ }^{75}$ For an introduction, see, Galbrath, J.K., Inequality: What Everyone Needs to Know, Oxford University Press, 2016. For Galbrath, there are two fundamental issues: first, the realisation that 'wealth is power' - and wealth is not just about income (p. 151); second, political institutions 'remain a bulwark against inequalities' (p. 111). 76 For example, referring to the U.S. political landscape, Jonathan Rothwell claims that the Left blames corporations while the Right points at unfair trade practices (and in times of populism, often times the arguments switch from one aisle to the other). Instead, he argues that the problem lies in the monopolization of key services. In this respect, it's unclear why he regards the Left's revived interest for antitrust as a limit. Cf. Rothwell, J., A Republic of Equals: A Manifesto for a Just Society, Princeton University Press, 2019. Rothwell also notes that the problem lies less in inequalities as such than in what society at large perceives as 'unfair' inequalities.
} 
otherwise doubling down on the existing project enough? Relative distribution and redistribution of wealth both within and among countries have traditionally been determined by at least four elements, namely: taxes, labour, trade, and prices. The problem is here twofold. On the one hand, these instruments are today largely ineffective in generating distribution and redistribution because they have been appropriated for achieving the diametrically opposite aims, that is, extraction of gains and concentration of wealth. On the other hand, human rights appear 'helpless' in this regard, for the human rights agenda rarely tackles any of such issues.

(a) Until very recently, human rights seemed to have little or nothing to say about taxes. ${ }^{77}$ Recent 'tax reforms' - that is, tax cuts for corporations and the wealthiest - have boosted buy-backs and dividends. But while stock markets have soared at record levels, ${ }^{78}$ wages have been stagnant ${ }^{79}$ despite several Western countries register increased productivity and some of the lowest unemployment rates since at least the 2007-2008 financial crisis. ${ }^{80}$ In other words, people work more (and more productively) to earn less. ${ }^{81}$ The contrast between financial gains and waged labour is of great importance. As Thomas Piketty has shown at length, one key cause - if not the key cause - of inequality has for centuries been the disparity in ownership of financial assets. The return on capital has been steadily higher than the return on paid labour. ${ }^{82}$ While there are proposals to impose

\footnotetext{
77 Until recently, literature in this area was scarce. The theme has been nonetheless gaining momentum in recent years. See, Beckett, P., Tax Havens and International Human Rights, Routledge, 2018; Alston, P. \& Reisch, N. (eds.), Tax, Inequality, and Human Rights, Oxford University Press, 2019.

${ }^{78}$ Egan, M., 'Market Milestone: This Is the Longest Bull Run in History', CNN Business, August 22nd, 2018. Also, Holmes, F. \& Great Speculation, 'Can the Bull Market Run Another 10 Years?', Forbes, March 7th, 2019.

${ }^{79}$ Limitedly to the United States, Mishel, L., Gould, E. \& Bivens, J., 'Report: Wage Stagnation in Nine Charts', Economic Policy Institute, January $6^{\text {th }}, 2015$. See also, Organization for Economic Cooperation and Development, Employment Outlook 2019: The Future of Work, OECD, 2019 (noting that unemployment has become less of an issue than stagnating wages). More recently, Stiglitz, J., 'Progressive Capitalism Is Not an Oxymoron', New York Times, April 19th 2019 . The theme is nonetheless controversial, as more liberal outlets contends the indicators and measures adopted to determine wage stagnation are misleading. Inter alia, Strain, M., 'The Story of Stagnating Wages Was Mostly Wrong', Bloomberg, May 15th, 2019; Gramm, P. \& Early, J., 'The Myth of "Wage Stagnation"', The Wall Street Journal, May 19th, 2019.

${ }^{80}$ For the United States, refer to the Employment Situation Survey by the Bureau of Labour Statistics at https://www.bls.gov/news.release/empsit.nr0.htm (last access, August 7th, 2019). For the European Union, data on employment are available on Eurostat at https://ec.europa.eu/eurostat/statisticsexplained/index.php/Unemployment_statistics (last access, August $7^{\text {th }}$, 2019).

81 To this point, one should further add the effects of automation and robotization. A recent proposal calls for taxing the work of machines. Cf. Rubin, R., 'The "Robot Tax" Debate Heats Up', The Wall Street Journal, January $8^{\text {th }}, 2020$.

82 Piketty, Capital in the Twenty-First Century. Those who own financial assets have been enjoying growing capital gains, whereas workers have suffered a progressive erosion of their wages. Financial assets are also
} 
taxes on financial transactions, ${ }^{83}$ there are currently only minor taxes on capital gain when taxation applies at all, for double taxation loopholes or tax minimisation strategies often allow to avoid taxes entirely. ${ }^{84}$ Furthermore, as inheritance taxes are either lifted or eluded in several rich countries, the result is a progressive concentration of wealth over time. ${ }^{85}$ In contrast, workers are today excluded from acquiring property once accessible to many, such as homes and cars; instead, higher prices, limited access to credit, and new market structures force workers into renting or leasing, for which they never acquire assets or equity. As Katharina Pistor has recently noted ${ }^{86}$ financial assets are pure legal creations: they do not exist without law - a law backed by a state willing and able to enforce it. It is thus curious how states are today effective in enforcing the set of contracts and other legal devices supporting the operations of financial markets, but seem unable to impose appropriate taxation on them. It is also interesting to note how firms and corporations have significantly improved the ability of states to tax labour and income, ${ }^{87}$ how states have repeatedly designed fiscal advantages, such as tariffs, to protect national firms and businesses, but for some reason the widespread belief is that states struggle to tax large transnational corporations. Insofar, the human rights movement has neglected the field of taxation. But taxes and rights are the fundamental skeleton of any state, for they decide the fundamental distribution of power and opportunities. As Alston and Reisch have recently noted: 'both taxation and human

tied up with collaterals, that is, with material assets (and vice versa). Hence, finance can leverage material wealth as well as expand it significantly.

${ }^{83}$ A first proposal was advanced by James Tobin, which has originated the name of 'Tobin Tax'. See, Tobin, J., 'A Proposal for International Monetary Reform' Eastern Economic Journal, 4:3/4 (1978), 153-159; reprinted, Tobin, J., 'A Proposal for Monetary Reform', Eastern Economic Journal, 29:4 (2013), 519-526.

84 The proposal for a tax on financial transactions, first put forward by the European Commission in 2011, is now gaining new traction because of the impact of high-frequency trading on security markets. See, Chung, K.H. \& Lee, A.J., 'High-Frequency Trading: Review of the Literature and Regulatory Initiatives Around the World', Asia-Pacific Journal of Financial Studies, 45:1 (2016), 7-33. Traditionally reluctant actors are more willing to accept a levy, which is presented as making markets more efficient while contributing to social justice, e.g., Buckley, R.P., 'Introducing a 0.05\% Financial Transactions Tax as an Instrument of Global Justice and Market Efficiency', Asian Journal of International Law, 4:1 (2014), 153-167.

85 Wagner, R., Death and Taxes: Some Perspectives on Inheritance, Inequality, and Progressive Taxation, American Enterprise Institute for Public Policy Research, 1973. More recently, Beckert, J., Inherited Wealth, Princeton University Press, 2008.

86 Pistor, K., The Code of Capital: How the Law Creates Wealth and Inequality, Princeton University Press, 2019.

87 Braithwaite, J., Regulatory Capitalism: How It Works, Ideas for Making It Work Better, Edward Elgar, 2008, pp. 23-24. Braithwaite describes the corporatization of the capitalist economy, suggesting how: 'one effect of the corporatization of capitalism in the twentieth century was that it made it easier for the state to collect taxes'. The contrast between corporate capitalism and middle-class capitalism is one of the themes dominating the contemporary political debate in the democratic primaries. See, e.g., The Economist, 'Elizabeth Warren Wants to Remake American Capitalism', The Economist, October 24th 2019. 
rights law are, in their essence, about the relationship between the individual and the state' $^{88}$ Their recent volume is a fundamental first step, as it acknowledges the fundamental interconnection between taxes and human rights in at least two respects: first, taxes should allow a relative redistribution of wealth, rather than income, thus limiting social marginalisation and exclusion; second, tax revenues are essential to finance those infrastructures and services that states are called to put in place in order to realise positive and negative human rights obligations. ${ }^{89}$ Alston and Reisch argue that 'tax and human rights are inherently intertwined and face a common challenge today: the reconceptualization of what constitutes a just society and the social good'.90 Their analysis engages with the liberal debate on whether civil rights or taxes are more effective in redistributing wealth and power in society, ${ }^{91}$ for taxes imply a greater role for the state, whereas rights should leave broader margin to private initiatives. Alston and Reisch do challenge the growing trend of 'privatisation' and they envision human rights as possible standard of fairness and legitimacy for taxation. However, they take for granted the power of states to collect taxes. The approach is therefore somewhat 'moral', for the underlying assumption is that paying taxes to states is 'good' for as long as states use that money to fulfil their human rights obligations. There are then 'good' states and 'bad' states, 'good' corporations and 'bad corporations'. What is missing is a more radical analysis of how, historically, the power of taxation has been exercised. The history of taxes is indeed a gloomy one: for taxation has been a key strategy of subjugation and extraction of wealth, of administration of populations and oppression of social groups, of war-making, and so forth. ${ }^{92}$ Hence, human rights should not just offer a formal analysis for the evaluation of fiscal policies: instead, the tension for human rights and taxes ought to offer the ground for a more radical and structural debate on

\footnotetext{
88 Alston \& Reisch (eds.), Tax, Inequality, and Human Rights, p. 19.

89 Avi-Yonah, R.S., 'Globalization, Tax Competition, and the Fiscal Crisis of the Welfare State', Harvard Law Review, 113:7 (2000), 1573-1676 (suggesting developed nations are in dire need of tax revenues).

${ }^{90}$ Alston \& Reisch, ibid.

${ }^{91}$ On this point, see, Kaplow, L. and Shavell, S.' Why the Legal System is Less Efficient than the Income Tax in Redistributing Income', The Journal of Legal Studies, 23:2 (1994), 667-681 (challenging the neoliberal assumption of the Chicago School about liberal rights as most effective mean in redistributing income and wealth).

92 The fact that virtually all states today print their own currency is a consequence of the historical difficulty for sovereigns to raise taxes to pay for their wars. To this day, a major share of tax revenues ends up paying for military expenses. For an extensive analysis on money, taxes, and power, see, Desan, C., Making Money: Coin, Currency, and the Coming of Capitalism, Oxford University Press, 2014.
} 
the nature of the state and its functions. ${ }^{93}$

(b) Human rights seem to have relatively little to say about labour. Not only human rights have little to say about labour, but they also interpret labour in fairly liberal terms. In abstract economic models, the free negotiation of wages in exchange for labour should guarantee a relative redistribution of wealth. In the real world, workers have been suffering an erosion of both rights and wages. It is not all about technology replacing workers, however. Several interconnected factors have contributed to the weakened position of workers. In the first place, the current model of globalisation guarantees the free circulation of capital and the relatively frictionless circulation of goods, but it restricts and regulates the mobility of workers. ${ }^{94}$ Controlling the circulation of labour force is functional to depress wages. ${ }^{95}$ Indeed, one 'mystery' of the liberal capitalist system is that while the free circulation of capital and goods increases their respective valuations, in those instances in which labour force is allowed to move, it is more likely to depress wages than to increase them. That is, the circulation of capital and labour generates completely opposite effects. Far from being a 'natural' law of economics, this situation is the product of a legal landscape that allocates gains and losses: a stronger promotion of investors' interests translates into an increasingly weak protection of workers' rights and wages. In the attempt of attracting investment in the form of either capital or business, different jurisdictions compete in offering advantageous tax regimes for investors and companies, shifting taxation burdens from corporate revenues to income from labour. Therefore, workers find themselves to be losers in at least three interconnected ways: stagnant or decreasing wages, higher taxation, but less public services. Indeed, the erosion of tax revenues has made it harder for countries to offer those public services - many of which contribute to the fulfilment of human rights

\footnotetext{
${ }^{93}$ Alston \& Reisch's volume is an impressive collection of high-quality contributions. Assessing and discussing such work is beyond the scope of the present contribution. We limit our analysis to repeat how Alston tends to offer solutions that might not be as radical as they should be, and how the role of the state is being revived by the very human rights that for long espoused a liberal narrative in favor of minimizing the role of states.

${ }_{94}$ Unger, R., Free Trade Reimagined: The World Division of Labor and the Method of Economics, Princeton University Press, 2007.

${ }^{95}$ Although the measure has broader political objectives, the 'Hukou' system in China is one example of how limiting the free movement of workers is functional to control the cost of labour. See, Wang, H., Guo, F., \& Cheng, Z., 'A Distributional Analysis of Wage Discrimination Against Migrant Workers in China's Urban Labour Market', Urban Studies, 52:13 (2015), 2383-2403; Song, Y., 'Hukou-Based Labour Market Discrimination and Ownership Structure in Urban China', Urban Studies, 53:8 (2016), 1657-1673.
} 
obligations - that alleviate the conditions of the lower class while enabling the middle class (e.g., free health care and free education, effective public transportation, etc.). In the international compartmentalisation of functions, labour falls within the competences of the International Labour Organisation, 96 which has drafted and ratified about two hundred conventions over time, mostly addressing the conditions of workers on the workplace. But while labour is safer and perhaps greener, ${ }^{97}$ it is becoming more and more challenging to find well-paid positions. Furthermore, a significant share of these standards and regulations are part of trade strategies that aim to preserve the dominance of some actors over others. Human rights are not only rather toothless under these conditions, but as Vidya Kumar has pointed out, the convergence of human rights and labour rights - i.e. the claim that "labour rights are human rights" - depoliticizes important conflicts in international law and thus hides the power disparities that labour law has been so good at revealing. If labour rights have traditionally focused on the relations between the worker and the employer, human rights are focused on the relations between the individual and the state. In a similar vein, if labour law has focused on power disparities, human rights emphasize the imagined equality of all human beings. Hence, recasting labour rights as human rights and thus reimagining the state as the antagonist of the worker and workers and employers as equals may deprive labour rights of their radical edge and shift focus away from concrete power relations of power and inequalities between workers and employers. ${ }^{98}$

(c) Trade is particularly impermeable to human rights concerns. At the same time, trade has enormous distributional consequences. In its current form, trade tends to concentrate gains in the hands of the few, while trade's promise of a better future for all brings the paradoxical outcome of marginalising democracy. ${ }^{99}$ The contemporary 'free trade regime' is an expression of sectorial interests in developed countries, the interests of

\footnotetext{
${ }_{96}$ Maul, D., Human rights, Development, and Decolonization: The International Labour Organization, 1940-70, Palgrave Macmillan, 2012 (noting the increasing tension between competing priorities).

97 Compa, L., \& Diamond, S., Human Rights, Labor Rights, and International Trade, University of Pennsylvania Press, 1996.

${ }^{98}$ Kumar, V., 'Rethinking the Convergence of Human Rights and Labour Rights in International Law: Depoliticisation and Excess,'in Ruth Buchanan and Peer Zumbansen eds, Law in Transition: Human Rights, Development and Transitional Justice (Hart Publishing, 2014).

${ }^{99} \mathrm{Cf}$. Rodrik, D., The Globalization Paradox: Democracy and the Future of the World Economy, W.W. Norton \& Company, 2011, p. xix.
} 
powerful corporations that successfully lobbied their respective government, translated into global rules. ${ }^{100}$ Although the global free trade regime is allegedly crumbling, ${ }^{101}$ the power behind it is stronger than it ever was. Despite significant economic growth, the volumes of international trade are decreasing because most trade occurs within corporations along so-called global value chains. ${ }^{102}$ Built through instruments of corporate law and private law, global value chains can be brutal: they allow corporations to achieve fiscal elusion, social dumping, 103 and avoid a series of other 'externalities' (e.g., compliance to labour and/or environmental regulations) by shifting these 'costs' onto less powerful actors or society at large. A growth in internal trade means that the allocation of resources is less concerned with efficiency and more with preserving the dominant position of the corporation. Indeed, trade is a field in which actors seek dominance. Some suggest that whichever position of dominance comes with costs to defend reputation. ${ }^{104}$ Although corporations might be sensitive to their reputation, they opt for private forms of self-regulation (i.e., Corporate Social Responsibility), ${ }^{105}$ for which human rights issues become part of a broader strategy for competitive advantage and

100 Stiglitz, J., 'Social Justice and Global Trade', Far Eastern Economic Review, $169: 2$ (2006), 18-22; Rodrik, D., Straight Talk on Trade: Ideas for a Sane World Economy, Princeton University Press, 2018.

101 Stiglitz, J., Globalization and Its Discontent Revisited: Anti-Globalisation in the Era of Trump, W.W. Norton \& Company, 2018.

102 Cf. Lund, S., Manyika, J., Woetzel, J., Bughin, J., Krishnan, M., Seong, J. \& Muir, M., Globalization in Transition: The Future of Trade and Value Chains, McKinsey Global Institute, 2019. Global Value Chains have a paradoxical combined effect: on the one hand, they make the world more interdependent; on the other, they also turn it more private and unequal. On the former aspect, see, Cattaneo, O., Gereffi, G., \& Staritz, C., Global Value Chains in a Postcrisis World: A Development Perspective, World Bank, 2010 (interdependence, however, does not mean that weaknesses and risks are evenly distributed along the chain).

103 Aguiar De Medeiros, C., \& Trebat, N., 'Inequality and Income Distribution in Global Value Chains', Journal of Economic Issues, 51:2 (2017), 401-408 (arguing that there are two forms of competition, one at the top of the chain and one at the bottom: the latter is about low wages, the former about the ability to protect intellectual property and capture gains). Stringer, C., \& Michailova, S., 'Why Modern Slavery Thrives in Multinational Corporations' Global Value Chains', Multinational Business Review, 26:3 (2018), 194-206 (with the rise in competition at the lower end of the chains GVCs favour forms of slavery).

104 Wheeler, S., 'Global Production, CSR and Human Rights: The Courts of Public Opinion and the Social Licence to Operate', The International Journal of Human Rights, 19:6 (2015), 757-778 (suggesting 'naming and shaming' could be effective in influencing corporations).

105 Ruggie, J., 'Report of the Special Representative of the Secretary-General on the Issue of Human Rights and Transnational Corporations and Other Business Enterprises', Netherlands Quarterly of Human Rights, 29:2 (2011), 224- 253; also, Ruggie, 'Business and Human Rights: The Evolving International Agenda', The American Journal of International Law, 101:4 (2007), 819-840; Ruggie, 'Protect, Respect and Remedy: A Framework for Business and Human Rights', Innovations: Technology, Governance, Globalization, 3:2 (2008), 189-212; Ruggie, 'Business and Human Rights: Together at Last?', Fletcher Forum of World Affairs, 35 (2011), 117-123; more recently, Ruggie, Just Business: Multinational Corporations and Human Rights, W.W. Norton \& Company, 2013. The UN has issued the so-called Ruggie's Guidelines or Guiding Principles on Business and Human Rights, Office of the High Commissioner for Human Rights, 2001 (HR/PUB/11/04). 
marketing. ${ }^{106}$ At the same time, states have increasingly shied away from leveraging antitrust laws, allowing some corporations to attain a virtually unrestrained global domain. ${ }^{107}$ As the economic and trade competition with China and South East Asian countries has intensified, developed economies have not only reversed their approaches to free trade, at times revamping protectionism, but also carefully balanced the risks of cracking down on dominant or rent positions: while this might favour national consumers, leveraging antitrust could also harm the national interests by weakening national enterprises in times of fierce economic competition. Take the macroscopic example of Amazon: ${ }^{108}$ why would the United States target Amazon with antitrust if the danger is to weaker the overall strategic position of the country against, say, China and its analogous platform of Alibaba? The two global giants are symptomatic of some major transformations occurring in global trade: with the rise of digital platforms and a growing use of proprietary data - more or less intrusively or even abusively 'mined' to feed algorithm, the world is witnessing a new wave of monopolies. ${ }^{109}$ As the role of these digital platforms becomes more and more infrastructural, the helplessness of human rights emerges all the more evidently:110 is it just a matter of privacy and consent? ${ }^{111}$ But isn't consent already an implicit admission of asymmetrical power?

\footnotetext{
106 Scheper, C., "“From Naming and Shaming to Knowing and Showing": Human Rights and the Power of Corporate Practice', The International Journal of Human Rights, 19:6 (2015), 1-20 (arguing that CSR proves the ability of capitalism to absorb and transform fundamental criticism). It has been recently noted how CSR have improved some aspects (e.g., child labour), while undermined others (e.g., unionization of workers), Crinis, V., 'Corporate Social Responsibility, Human Rights and Clothing Workers in Bangladesh and Malaysia', Asian Studies Review, 43:2 (2019), 295-312.

${ }^{107} \mathrm{~A}$ vocal critic of the current inertia in antitrust, Wu, T., 'Taking Innovation Seriously: Antitrust Enforcement if Innovation Mattered Most', Antitrust Law Journal, 78:2 (2012), 313-328. More recently, Wu, T., The Curse of Bigness: Antitrust in the New Gilded Age, Global Reports, 2018.

108 Khan, L.M.,'Amazon's Antitrust Paradox', Yale Law Journal, 126:3 (2017), 710-894.

${ }_{109}$ Zuboff, S., The Age of Surveillance Capitalism: The Fight for a Human Future at the New Frontier of Power, Public Affairs, 2019. Calling for a less enabling role of international lawyers in shaping the new world of 'big data', Johns, F., 'The Deluge', London Review of International Law, 1:1 (2013), 9-34.

110 Joyce, D., 'Privacy in the Digital Era: Human Rights Online?', Melbourne Journal of International Law, 16:1 (2015), 270-285 (noting the relative inability of the UN General Assembly to cope with the complexity of the current transformations).

111 Privacy is the pillar of the European Union's approach to digital platforms and data transfer, Marc Rotenberg, \& David Jacobs. (2013), 'Updating the Law of Information Privacy: The New Framework of the European Union', Harvard Journal of Law \& Public Policy, 36:2 (2013), 605-652. Also, Johns, F. \& Joyce, D., 'Beyond Privacy: Is Prevailing Legal Debate Too Analog for a Digital Age?', Human Rights Defender, 23:3 (2014), 2426. Compliance is however insufficient, Jørgensen, R., \& Desai, T., 'Right to Privacy Meets Online Platforms: Exploring Privacy Complaints against Facebook and Google', Nordic Journal of Human Rights, 35:2 (2017), 106126.
} 
(d) Human rights actors might find it legitimately difficult to understand how to engage with prices. But prices are a crucial part of today's economy and they express the value society attributes to specific goods and services. Some major transformations of the global economy are affecting the way prices are set. For instance, digital platforms are only one side of the increasing 'virtualisation' of trade, the other side being the share of trade in intangibles, which include financial assets. Intangibles require strong protection of property, most notably intellectual property. Intellectual Property Rights (IPRs) have been globalised through the World Trade Organisation (WTO), ${ }^{112}$ as membership to the organisation is made dependant on signing up to the Agreement on Trade Related Aspects of Intellectual Property Rights (TRIPS). Engineered by the Intellectual Property Committee, a coalition of thirteen CEOs from the America largest pharmaceutical, software, and entertainment companies, the TRIPS Agreement established a global regime 'that reaches deep into the domestic regulatory environment of states' under the disputable narrative that they protect inventors and human ingenuity. ${ }^{113}$ However, what IPRs actually do is to securitise investors, while allowing an unprecedented leverage in setting the prices for goods. Indeed, IPRs are an essential tool for promoting a 'subjective' theory of prices, meaning that goods are not sold at a price reflecting their production costs or societal value, but rather aiming at the highest possible price the buyer is able to pay. ${ }^{114}$ This practice dramatically affects, for instance, the cost of medicines, as pharmaceutical companies can freely set prices, often leveraging the fact that states or insurers have an obligation to cover the costs for a given pathology. ${ }^{115}$ IPRs are also effective in capturing value at the expenses of the broader supply chain, for the gains from trade are unequally distributed between labour input and the value of the licensed patent or brand. Ironically, royalties on IPRs can benefit from privileged tax treatment. 116

\footnotetext{
112 Drahos P., The Universality of Intellectual Property Rights: Origins and Development, World Intellectual Property Organization, 1999.

113 Sell, S.K., Private Power, Public Law: The Globalization of Intellectual Property Rights, Cambridge University Press 2003, p. 1. See also, Deere C., The Implementation Game: The TRIPS Agreement and the Global Politics of Intellectual Property Reform in Developing Countries, Oxford University Press, 2009.

114 Mazzucato, M., The Value of Everything: Making and Taking in the Global Economy, Penguin Books, 2018, pp. 207-228 (with particular reference to the pricing of medicines).

115 As Amy Kapczynski puts it, 'a right to medicines imbricated into this regime is plausibly regressive: it places significant strain on healthcare budgets, redistributes upwards, and provides medicines on terms largely dictated by one of the most profitable industries in the world'. Kapczynski, A, 'The Right to Medicines in an Age of Neoliberalism', Humanity Journal, 10:1 (2019), 79-107 at 81.

116 Blair-Stanek, A., 'Intellectual Property Law Solutions to Tax Avoidance.', UCLA Law Review, 62:1 (2015), 273 (arguing that against the inefficacy of tax law, changes ought to be made in intellectual property).
} 
IPRs offer an interesting and effective example of how value is extracted and accumulated: law enables the growing dominance of finance and thus the financialisation of the economy and life more broadly. Finance has become effective in capturing gains at the expenses of other stakeholders. The rise of finance corresponds with an age of globalisation, de-regulation, and inequalities. For instance, the success and prosperity of the financial sector has also corresponded to an explosion of public and private indebtedness. ${ }^{117}$ It is thus ironic how the solution to the problem is at times indicated in a more inclusive system, perhaps making credit scores to access loans 'fairer' (i.e., financial inclusion and inclusive capitalism). ${ }^{118}$ Much of the contemporary financialised economy aims to maximise 'shareholders' value', that is, to more or less artificially increase the price of publicly traded shares. But this means privileging one group of people over others. One main challenge for human rights is then to rebalance the interests of different social groups. This might require reframing the meaning of 'value' in society, ${ }^{119}$ which would also imply redesigning the role of finance.

For better or worse, the human rights movement has so far opted for engaging in somewhat ideological battles in the public sphere, thus neglecting those more technical aspects that have allowed to erect and establish unprecedented forms of private power on a global scale. Distribution and redistribution are decided by:

'[B]y and large, private law regimes such as contract law, corporate law, tort law, property lay, tax law, intellectual property law, commercial arbitration (...) as well as a vast array of private ordering regimes and business practices, including practices to create and exploit commercial advantage as well as industry association standards, corporate codes of conduct and other business-led corporate social responsibility mechanism' ${ }^{120}$

\footnotetext{
117 The International Monetary Fund has recently launched a Global Debt Database, accessible at: www.imf.org/external/datamapper/datasets/GDD (last access, August 7th, 2019). Although the data are still partial, it is possible to observe an increase in both public and private debt over the last decades.

${ }^{118}$ Fleissner, C. 'Inclusive Capitalism Based on Binary Economics and Positive International Human Rights in the Age of Artificial Intelligence', Washington University Global Studies Law Review, 17:1 (2018), 201-244 (supporting the idea of fuller employment to favour income distribution).

119 Lazonick, W., 'Profits Without Prosperity', Harvard Business Review, 92:9 (2014), 46-55. Jacobs, M. \& Mazzucato, M., Rethinking Capitalism: Economics and Policy for Sustainable and Inclusive Growth, WileyBlackwell, 2016.

${ }^{120}$ Danielsen, D., "Situating Human Rights Approaches to Corporate Accountability in the Political Economy of Supply Chain Capitalism" in Brinks, D., Dehm, J. and Engle, K. (eds.), Power to People? Private Efforts to
} 
Therefore, the traditional human rights strategy to hold states accountable for violations of individual rights seem toothless and ill-equipped to deal with the root causes of socioeconomic inequalities in contemporary societies. One could fathom that human rights could still exercise pressure on governments to enact laws and policies to guarantee a certain degree of material equality between citizens. However, there are at least two obstacles. The first is that even in some developed countries, governments have less and less room for manoeuvre. The constraints are said to descend from the political economy of the world, but they are ultimately legal: if a government is pressed in between international investment treaties and human rights obligations, the former will likely prevail. A second obstacle is internal to the human rights movement. As Samuel Moyn has recently argued, to the extent the human rights movement has been mobilised to deal with inequalities, it has settled to easily to raising individuals above the minimum standard of sufficiency. ${ }^{121}$ In other words, it has prioritised sufficiency over equality, thus serving as an unwitting companion to the neoliberal project that has brought forth 'a golden age of the rich'. ${ }^{122}$ In this respect, the human rights movement needs not only better tools to engage into the battlefield of private law, but also a different narrative to disentangle human rights from its complicity with neoliberalism.

\subsection{The 'Complicity' Problem}

The 'age of rights' has corresponded to an explosion of socio-economic inequalities and a 'golden age of the rich'. It is thus fair to question whether human rights might have played a role in that by looking at two dimensions, namely a structural and cultural aspects respectively. In contemporary debates, inequalities are directly associated with the effects of neoliberal policies. While Samuel Moyn sees no immediately interconnection between neoliberalism and human rights, thus characterising human rights as a 'powerless

\footnotetext{
Enforce Human Rights in Supply Chains, forthcoming 2019. It has also been argued that international private law is not necessarily antagonistic to human rights, Watt, H., 'Competition or Confluence? Private International Law and Human Rights in Global Governance', Revue Internationale De Droit Économique, 27:1-2 (2013), 59-78.

${ }^{121}$ Moyn, Not Enough.

122 Ibid., p. 58.
} 
companion' to the neoliberal project, ${ }^{123}$ Jessica Whyte has recently challenged such view, showing an ideological and structural complicity between them. Whyte indeed argues that the hegemonic versions of human rights have been turned into 'the morals of the market',124 that is, into an effective tool for refuting socialist and postcolonial demands for greater economic equality, while upholding 'a neoliberal right to equality [as] a right of everyone to preserve their unequal wealth and power in the face of political demands for redistribution'.125 The present part does not directly engage with such debate, ${ }^{126}$ but it touches on themes that are relevant to it. On the one hand, the human rights language has been used to produce or strengthen some of the legal and economic structures that produce today's radical inequality. On the other, the culture and practices of the human rights movement appear to be broadly liberal, for they embrace the primacy of the private, a certain idea of economic freedom, a preference for technical expertise over politics, and so forth.

(a) A first aspect of complicity concerns the use of human rights for creating or reinforcing the legal and economic structures generating radical socio-economic inequalities. Taken as such, human rights are neither neoliberal nor capitalist, but they might have been instrumentalized into those projects. The inherent emptiness of the rights language has allowed different actors to deploy human rights for interests and purposes contradicting the history and aspirations of the human rights project. For instance, neoliberals have been able to co-opt and redefine human rights to fit them into their own project, recasting trade, market, and capital rights as actual human rights. Since the very start of the neoliberal project in Vienna and Geneva, the fundamental concern was 'the sanctity of capital mobility'. The aim was to demolish state constraints, that is, to gain access to foreign countries as well as - far more importantly - to have 'the right to sell and leave'.127 In more recent times, Ernst-Ulrich Petersmann replied to the mounting

\footnotetext{
${ }^{123}$ Moyn, S., 'A Powerless Companion: Human Rights in the Age of Neoliberalism', Law \& Contemporary problems, 77:4 (2014), 147-169.

124 Whyte, J., The Morals of the Market: Human Rights and the Rise of Neoliberalism, Verso, 2019, p. 34

125 Whyte, The Moral of the Market, p. 24.

${ }^{126}$ On the intellectual history of neoliberalism, see also, Slobodian, Q., Globalists: The End of Empire and the Birth of Neoliberalism, Harvard University Press, 2018.

127 Slobodian, Q., Globalists: The End of Empire and the Birth of Neoliberalism, Harvard University Press, 2018, p. 145.
} 
questioning on the legitimacy of the WTO by adopting the very human rights language of protesters, conveniently reinterpreting it as to demand more effective protection of economic freedoms and property rights. ${ }^{128}$ The neoliberal reinterpretation of human rights has not always encountered the sort of strenuous resistance that one might expect from the human rights movement. To the contrary, several human rights and humanitarian NGOs have mobilised human rights language to counter Third World demands for economic redistribution. ${ }^{129}$ Indeed, they rejected the idea for which poverty would be the by-product of the prosperity in the global North, thus placing the responsibility for the plight of the Third World on post-colonial leaders accused of corruption or to oppress their own peoples. This is all the more relevant if one considers the timing: when the New International Economic Order rose to challenge the postcolonial structures of the political economy of the world, human rights ultimately sided with neoliberalism in pushing back. ${ }^{130}$ Considering these historical linkages, it is unsurprising that neoliberals have found human rights a rather useful tool. There are several conceptual connections between human rights and the neoliberal project. Both insist in a relative absoluteness of individual rights against the intrusion and pretenses of governments and states. Human rights offer substantive and procedural guarantees, while also de-politicising particular disputes. Indeed, human rights have somehow espoused the neoliberal logic for which the realm of human emancipation and the only desirable public sphere ought to be found in the market. Moving from this assumption, not only human rights protect private property in fairly strong terms, but they also extend their guarantees to legal persons, that is, companies. ${ }^{131}$ But what does the human rights movement have to say about the increasing privatisation of litigations, that is, the shift from court litigations to private arbitrations or confidential settlements? ${ }^{132} \mathrm{~A}$

\footnotetext{
128 Ibid., pp. 277-279. See, e.g., Petersmann, E.U., 'The WTO Constitution and Human Rights', Journal of International Economic Law, 3:1 (2000), 19-25; Petersmann, E.U., 'Human Rights and International Economic Law in the 21 ${ }^{\text {st }}$ Century: The Need to Clarify Their Interrelationship', Journal of International Economic Law, 4:1 (2001), 3-39.

129 Jessica Whyte has convincingly demonstrated how Liberté sans Frontières (LSF), an organisation established by the French leadership of Médecins sans Frontières (MSF), rejected Third World instances and demands using human rights. Whyte, J, 'Powerless Companions or Fellow Travelers? Human Rights and the Neoliberal Assault on Postcolonial Economic Justice ', Radical Philosophy, 2:2 (2018), 13-29.

${ }^{130}$ For instance, human rights helped re-signify 'state-led redistribution as a totalitarian threat to liberty and human rights'. Ibid., p. 26

${ }^{131}$ For an overview in the European context, Emberland, M., The Human Rights of Companies: Exploring the Structure of ECHR Protection, Oxford University Press, 2006.

132 For instance, there has been a growing reliance on compulsory arbitration clauses in labour contracts. With
} 
complete mapping of the way human rights intertwine with neoliberalism is beyond the scope of the present paper. But it is worth stressing that far from being 'indivisible, interdependent, and interconnected',133 human rights are often times fragmented and deployed strategically through a selective use and enforcement: some rights are privileged over others; the same rights can be mobilised differently for different projects; and all rights are often interpreted and enforced rather selectively. The end result is that human rights have for some become the 'human rights of capital' ${ }^{134}$

(b) A second aspect pertains to a more sociological sphere, that is, the culture and practices of the human rights movement itself. One traditional critique of human rights is that they belong to a specific social class. For instance, Libby Adler has pointed how the LGBT agenda has been seized to reflect the priorities and interests of a relatively welloff group of activists and donors. Indeed, 'access to marriage was at the forefront of the battle for LGBT advancement for more than a decade, along with anti-discrimination protection, [and] hate crimes legislation' ${ }^{135}$ At the same time, the many socio-economic problems of LGBTQIA people were entirely disregarded, starting with a rampant percentage of homelessness and a higher exposure to health risks. In other words, the priorities and interests of an 'adequately housed and well-nourished class' obscured and neglected the 'pressing needs in the most marginalised sectors of that community'. ${ }^{136}$ As activism is often dependent on donors, whether private or institutional, a significant part of the work for any human rights organisation has become fund-raising. A fierce competition to attract donations means that 'donors' can directly or indirectly dictate priorities, conditions, and modalities. Ultimately, this carries the risk of turning human rights organizations into companies that embrace the 'shareholders' mentality. Another common critique to human rights is that they are part of a liberal culture, which places courts and legal litigations at the center stage. But access to courts is not as democratic as it should be and its outcomes impact people differently. Those who have the necessary

reference to the United States, see, the dedicated issue on the Berkeley Journal of Employment and Labor Law, 35:12 (2014).

133 Vienna Conference on Human Rights, 1993.

134 Cooper, F., 'Afterword: Social Rights and Human Rights in the Time of Decolonization', Humanity, 3 (2012), 473-492 at 487.

135 Adler, L., Gay Priori: A Queer Critical Legal Studies Approach to Law Reform, Duke University Press, p. 2.

136 Adler, Gay Priori, pp. 2-3. 
financial means can not only access courts more easily, but also hire more specialised lawyers. For example, it has been noted that human rights litigations to gain access to medicines or medications favour the middle class ${ }^{137}$ in at least two significant ways. First, whatever litigation primarily promotes the specific interests of those who brought the case in first place. Sometimes, the situation is even more confusing than that: law firms offer to take on strategic litigations pro bono, while interest groups can finance court cases when they believe it could advance their agenda. Secondly, individual human rights cases can significantly erode the ability of the state to provide public health services because litigations as such as well as successful litigants who are awarded compensations erode the budget, which translate into a cut to services that generally tend to bear more importance to the poor. ${ }^{138}$ Therefore, although human rights litigations are usually presented as pursuing a general public or collective interest, the case of access to medicine proves that this is not always the case. Generally speaking, the human rights movement and its activism are both diverse and disperse. ${ }^{139} \mathrm{~A}$ significant part of the human rights activism intervenes in response to situated crises that do not receive adequate institutional responses, whether locally or internationally. As the human rights movement becomes increasingly specialised and promotes legal cases focusing on narrow points, there is indeed a disconnection between the aim of specific instances and the broader picture. Human rights interventions turn into technical matters, embedding human rights in the culture of expertise. Thus, human rights bend to the inner logic of expertise, thinking like it: they seek specialisation, efficiency, managerialism, and so forth. Therefore, although speaking of root causes of human rights violations have become somewhat fashionable within the human rights movement, there is often little engagement with 'the larger framework within which

\footnotetext{
137 See, e.g., Kapczynski, 'The Right to Medicines in an Age of Neoliberalism'; Ferraz, O.L.M., 'The Right to Health in the Courts of Brazil: Worsening Health Inequities?', Health and Human Rights ,11:2 (2009), 33-45; Ferraz, O.L.M., 'Moving the Debate Forward in Right to Health Litigation', Health and Human Rights, 18:2 (2016), 265-268; Brinks, D.M. \& Gauri, V., “A New Policy Landscape: Legalizing Social and Economic Rights in the Developing World", in Gauri and Brinks (eds.), Courting Social Justice: Judicial Enforcement of Social and Economic Rights in the Developing World, Cambridge University Press, 2008.

138 Reports show that 'litigants frequently obtain expensive and even ineffective medicines that are not recommended by or included in the national formularies that determine what public and private insurers must provide'. Nonetheless, 'courts [can] demand that medicines be provided regardless of their cost, but health budgets are necessarily limited'. Kapczynski, 'The Right to Medicines in an Age of Neoliberalism', p. 78.

139 This is both a point of strength and weakness, as noted by Simmons, B.A., 'The Future of the Human Rights Movement', Ethics \& International Affairs, 28:2 (2014), 183-196.
} 
those conditions are systematically reproduced'. ${ }^{140}$ As human rights activism and battles become more bureaucratic, addressing a given human rights violation may ultimately obfuscate the bigger picture, that is, the conditions of possibility for human rights violations. In turning human rights battles 'technical', even situations like world hunger are made to appear as natural phenomena inscribed into a history of progress instead of the direct outcome of a human-created economic system.

Human rights suffer from two problems, namely helplessness and complicity. Human rights are instrumentalized, whereas the movement seem to share, at least in part, certain mind-sets and practices with neoliberal capitalism. As a consequence, human rights contribute to shape a largely de-politicised world dominated by formal and functional expertise, a world of struggles in which private interests shape the public discourse and institutions to achieve dominance. ${ }^{141}$ Hence, instead of being the voice of the voiceless, human rights risk becoming part of the toolbox of the powerful to assert and advance their projects and interests. As economic and material interests prevail over the effective protection of people, the peril for the human rights movement is to become, more or less unawarely, the guardians of that unequal political economy of the world that it should instead fight. For these reasons, we do not believe that simply doubling down on the existing human rights project with the help of 'familiar strategies' enough. Rather, we need a much more radical approach to human rights.

\section{Reflections}

In the human rights movement, the rise of populist movements has ignited a sense of crisis. The once liberal, democratic, and internationalist Western world is slowly drifting towards more or less marked forms of authoritarianism. In the face of this historical phase, Philip Alston has intervened to defend the merits of the human rights project and double down on it. He has identified a series of problems and advanced a strategy for confronting what he defines as 'unprecedented challenges'. However, the present paper has argued two main

\footnotetext{
140 Marks S., 'Human Rights and Root Causes', Modern Law Review, 74:1 (2011), 57-78 at 71.

141 Kennedy, D., A World of Struggle: How Power, Law, and Expertise Shape Global Political Economy, Princeton University Press, 2016.
} 
things: first, the struggle Alston identifies against populism might turn out misleading; second, the Alston's proposed strategy may prove either ineffective or counter-productive. Indeed, we have aimed at expanding the existing conversation to show how Alston's doubling down on a 'familiar strategy' may fall short from tackling socio-economic inequalities because of some deeper problems that affect the human rights regime and movement.

The human rights project 'has never been a consensus project. It has almost always been a product of struggle'.142 But not all struggles bear the same weight. In Alston's view, the challenge to face is about populism. However, populism is only a tactic that even the human rights movement itself has occasionally made use of. In contrast, the struggle is between human rights and the re-emerging forms of nationalism, which - in all their differences seem equally regressive both psychologically and materially. That is to say, they bring a reflux of xenophobia with an obsession for security, both of which lead to the dismantling of welfare provisions. While the nationalism of the late $19^{\text {th }}$ and early $20^{\text {th }}$ centuries had some vague elements of solidarity, contemporary nationalism is solely identitarian. Nationalist movements leverage the discontent for globalisation and the range of inequalities it brought with it. But what they have to offer is far from their actual rhetoric: most nationalisms have so far privileged those very elites they were meant to battle.

The first great challenge for the human rights movement is therefore that of locating and identifying the actual struggle. Today, there are ghostly forms of dominance that mainstream versions of human rights are unequipped to challenge. A traditional logic of 'naming and shaming' can only superficially - and thus insufficiently - scratch a system of dominance largely built upon and throughout forms of private law. ${ }^{143}$ Engaging with private law also means that power is hardly visible and centralised. Geneva and New York, for how relevant, cannot become the sole focus of action. Hence, the movement ought to

\footnotetext{
142 Alston, 'The Populist Challenge', p. 3.

143 See, e.g., Watt, H., 'Competition or Confluence? Private International Law and Human Rights in Global Governance', Revue Internationale De Droit Économique, 27:1-2 (2003), 59-78; Watt, H., “Theorizing Private International Law", in Orford, A. and Hoffman, F. (eds.), The Oxford Handbook of the Theory of International Law, Oxford University Press, 2016, pp. 862-882; Watt, H., 'When Societal Constitutionalism Encounters Private International Law: Of Pluralism, Distribution, and "Chronotopes"', Journal of Law and Society, 45:1 (2018), 185203.
} 
reach 'the ends of the network, where people are using human rights promiscuously as they build power locally'. ${ }^{144}$ In other words, the effects of an increasingly sophisticated and private dominance are felt first and foremost in local and apparently marginal instances.

Human rights have already won many battles. It is thus understandable how one could imagine confronting today's challenges of populism and inequalities with 'the recipe that we have developed for civil and political rights promotion', that is, recognition, institutionalisation, and accountability - just applied to economic and social rights. However, the human rights movement has first to sort out its complicity with that very system it aims to transform. There is need for a human rights movement that sees and reveals rather than denies connections between rights and markets'. ${ }^{145}$ Human rights have to come to terms with their recent past, their relation to markets, as well as their own power. That is, the embeddedness of human rights within the political economy of the world and,146 as Jessica Whyte has noted, the complicity of human rights with neoliberalism. Without doing so, the danger is to repeat mistakes and be ineffective at best or damaging at worst. For instance, there is the relative risk to create a new group of international experts that will ultimately establish de-politicised bureaucratic processes and vocabularies, exploiting struggles rather than fighting them. ${ }^{147}$ The future of human rights and their movement cannot be one of further de-politicisation.

The struggle against nationalist movements is ultimately one of narrative and imaginary. In this battle, human rights must be able to win back the streets, politics and media and be able to work with different actors from environmentalists to labour unions which are more equipped to deal with some of the issues that have contributed to the current situation. ${ }^{148}$ Although Alston laments that academic critiques of human rights serve little purpose other than infusing a sense of hopelessness into students, we believe it is through critique that

\footnotetext{
144 Kapczynski, A., 'What Comes after Not Enough?', Law and Political Economy Blog, available at https://lpeblog.org/2018/06/11/what-comes-after-not-enough/ (last access, August 5th, 2019)

145 Kapczynski, 'What Comes after Not Enough?'.

146 Manfredi, Z., 'Recent Histories and Uncertain Futures', Qui Parle, 22:1, 2013, 3-32, p. 5: 'human rights are not only inefficacious tools but also collaborators in a pernicious politics of inequality and domination'.

147 Koskenniemi, 'Human Rights Mainstreaming as a Strategy for Institutional Power'.

148 Goldston, J.A., 'A Wake-up Call for Human Rights', Project Syndicate, available at https://www.projectsyndicate.org/commentary/human-rights-groups-criticism-populism-by-james-a-goldston-2019-08 (last access on August 21st, 2019).
} 
new narratives can emerge to regenerate the human rights enterprise. Part of the task is historiographical,149 for the neoliberal hijacking of human rights has foreclosed alternative and potentially more powerful traditions that should be rediscovered and revived. 150 Historically, the forgotten foundational principle of not solely human rights, but also of nations, is less that of formal equality than that of solidarity. Indeed, the debate about and around formal versus absolute equality is inevitably inconclusive: full material equality is impossible (for there can never be a condition in which everyone is equal to everybody else in everything) while formal equality is insufficient. Just like freedom and equality cannot be taken apart, 151 so do equality and solidarity. For formal equality to be effective, it has to come with solidarity ties based not a mere sufficiency but on mutual insurance and redistribution. The French Revolutionaries proclaimed 'freedom, equality, and brotherhood', the latter being a demand for material solidarity among the members of the same community. At the same time, the idea of nation, as it emerged throughout the 19th and $20^{\text {th }}$ centuries, was an imagined community that entailed a fundamental principle of solidarity among its members, a solidarity that entailed a public form of mutual insurance.

Contemporary forms of nationalism replace material solidarity with empty narratives about 'crippled' identities, that is, national identities that can only stand in opposition to some 'enemy' ${ }^{152}$ they instrumentalize migration to antagonize the 'other' and create a fictitious sense of community under attack, to denigrate global solidarity while also cutting back on those material forms of national solidarity known as welfare, to marginalise the role of the state in providing for its less fortunate members at the advantage of private forms of philanthropy. Therefore, one way the human rights movement can take over the new wave of nationalism is to offer more credible and tangible answers: against the erosion of social

\footnotetext{
149 There has already been a historiographical turn in the field of human rights. See, Moyn, S., The Last Utopia: Human Rights in History, The Belknap Press of Harvard University Press, 2010; Moyn, S., Human Rights and the Uses of History, Verso, 2014; Alston, P., 'Does the Past Matter? On the Origins of Human Rights', Harvard Law Review, 126, 2012-13, 2043-2081; Slotte, P. and Halme-Tuomisaari, M. (eds.), Revisiting the Origins of Human Rights, Cambridge University Press, 2015.

${ }^{150}$ For example, see, Marks, S., A False Tree of Liberty: Human Rights in Radical Thought, Oxford University Press 2019.

${ }^{151}$ Balibar, E., 'The Proposition of Equaliberty', in Equaliberty, Duke University Press, 2014, pp. 67-98.

152 The binomial 'friend-and-enemy' revives the unhappy characterization of the political given in Schmitt, C., The Concept of the Political, Chicago University Press, 2007, p. 26.
} 
bonds and state welfare, human rights can revive the forgotten principle of collective solidarity both within and beyond national borders. 


\title{
HUMAN RIGHTS, POPULISM, AND THE POLITICAL ECONOMY OF THE WORLD
}

\begin{abstract}
The commonly shared sentiment that human rights have reached a crisis in the form of a populist backlash has produced a vibrant discussion on the causes of and solutions to the crisis. This article seeks to contribute to that discussion by engaging with Philip Alston's important and influential essay on the topic, and in particular with his project of tackling material inequality. In so doing, the article makes two main points. First, it argues that the populism is most of all a form or a tactic, whereas the true antagonistic opponent of human rights might be the nationalist substance of populism. Secondly, the article agrees with Alston that a key reason for the populist backlash is material inequality, but challenges his view that the solution to the problem is to double down on 'familiar strategies', with the addition of providing social and economic rights a more prominent position within the human rights project. By contrast, the article suggests that a radical renewal of the human rights movement is called for - one accompanied by a more elaborate diagnosis of how human rights have been linked to inequalities and how they can engage with the structures and actors producing those inequalities. Trying to understand why human rights have lost ground to nationalism, the article suggests that a first step towards such more radical and dynamic human rights might be to unearth the now largely forgotten concept of solidarity, which once played a key part in the motto 'liberty, equality, fraternity'.
\end{abstract}

Keywords: human rights, inequality, Philip Alston, populism, social and economic rights, solidarity

\section{Introduction}

A crisis is often an opportunity for development or transformation. ${ }^{1}$ Such could be the case also for human rights - intended both as project and as discipline - which many see challenged the a so-called 'populist backlash'. Indeed, the populist challenge has produced a vibrant discussion regarding the future of human rights and the accomplishments and

\footnotetext{
1 The notion of 'crisis' would deserve a much longer discussion, as it can acquire significantly diverse meanings. For a brilliant conceptual analysis, see: Koselleck, R., 'Crisis', Journal of the History of Ideas, 67:2 (2006), $357-400$.
} 
shortcomings of what this article refers to as the 'human rights movement' 2 - a contested term which is used here to refer in particular to a wide range of mainstream, global human rights actors, including the best known (often Western) human NGOs, experts, scholars, and institutions; but mostly excluding more localized and grassroots forms of human rights activism.

One of the most important aspects of this discussion has been its increasing focus on issue of material inequalities, which is commonly seen as one of the root causes of the populist backlash. As critics have asked, is it not puzzling that the 'age of rights' 3 has coincided with a sharp increase in inequalities both between and within countries? ${ }^{4}$ How has the 'age of rights' become an 'age of inequalities' ${ }^{5}$ Is this just a coincidence or do human rights play a part in the political economy of the world? ${ }^{6}$

This article seeks to contribute to the discussion on the populist backlash, and in particular to the issue of human rights and inequality, by engaging with Philip Alston's insightful and influential essay on the topic. ${ }^{7}$ In seeking to galvanize human rights proponents against looming loss of faith, Alston touches on several pertinent issues regarding the crisis of human rights, one of which is of particular interest for the present article. This is his suggestion of tackling the questions of inequalities with increased focus on social and economic rights while doubling down on the familiar human rights strategies of recognition, institutions and accountability. ${ }^{8}$ Although we agree with Alston that increased

\footnotetext{
2 On the difficulty of using the term, see Alston, P., 'Reply to Dudai and Nagaraj', Journal of Human Rights Practice, 9 (2017), 25-28, pp. 25-26. On the history of the human rights movement, see Neier, A. The International Human Rights Movement: A History, Princeton University Press, 2012. Tracing the history further into the past, see Iriye, A., Goedde, P., \& Hitchcock, W., The Human Rights Revolution: An International History, Oxford University Press, 2012.

${ }^{3}$ The expression 'age of rights' has been notably coined by Henkin, L., The Age of Rights, Columbia University Press, 1990; for a similar account from the field of political theory, Bobbio, N., The Age of Rights, Polity Press, 1996 (also offering a periodization of human rights).

${ }^{4}$ For a recent, influential analysis on the interconnection, see: Moyn, S., Not Enough: Human Rights in an Unequal World, The Belknap Press of Harvard University Press, 2018.

${ }^{5}$ See, Milanović, B., Global Inequality: A New Approach for the Age of Globalization, The Belknap Press of Harvard University Press, 2016. For a more extensive and equally notorious analysis over a much longer timeframe, Piketty, T., Capital in the Twenty-First Century, Harvard University Press, 2014 (making the point that a major cause of inequalities is the differential between the return rate on capital and on labour).

6 See, Kinley, D., Civilizing Globalization: Human Rights and the Global Economy, Cambridge University Press, 2009; Whyte, J., The Morals of the Market: Human Rights and the Rise of Neoliberalism, Verso, 2019.

7 Alston, P., 'The Populist Challenge to Human Rights', Journal of Human Rights Practice, 9 (2017), 1-15.

${ }^{8}$ Ibid., p. 9.
} 
focus on social and economic rights is needed, we dispute that doubling down on the existing project is the best path forward. By contrast, in arguing that the 'crisis' of human rights might be less about populism than its entanglement or complicity with an unequal distribution of opportunities and resources around the world, we suggest that defending human rights might require a deeper and more granular understanding of how and to what extent human rights have been 'part of the problem'. 9

The article is comprised of four further sections. Section 2 briefly outlines Alston's main arguments and the responses it has attracted. The next two sections engage with two of Alston's arguments in more detail. Section 3 contends that today's main challenge for the human rights and the movement supporting them is less about pushing back on populism and the nationalist agendas they support than to focus on structural and distributional problems. Section 4 takes on Alston's aforementioned plan of doubling down on the existing human rights project, albeit with added focus on social and economic rights, by pointing out two key challenges in this regard: the incapacity of current conceptions of human rights to address some root causes of inequality, and their possible complicity to other such causes. Section Five argues that every 'crisis' is also an opportunity. In so doing, it suggests that a path forward for the human rights movement could be provided by unearthing the forgotten concept of solidarity and thus drawing from a now marginalized but more radical tradition of human rights thinking.

\section{Introduction}

In a recent article, Philip Alston confronts the current backlash on human rights, sketching out a possible path forward. ${ }^{10}$ Alston's contribution is important not solely because of the substantive insights he provides, but also because of his role of leadership within the human rights movement and regime. For Alston has an incredible track record: he is one of the most - if not the most - renown international human rights scholars, a prominent supporter and maker of the human rights regime, who has indeed held several prestigious appointments

\footnotetext{
9 The choice of words is inspired by Kennedy, D., 'International Human Rights Movement: Part of the Problem?', Harvard Human Rights Journal, 15 (2002), 101-125.

10 Alston, 'The Populist Challenge', pp. 4-7. See also, Alston, P., 'Human Rights Under Siege', International Journal on Human Rights, 14:25 (2017), 267-272.
} 
at the United Nations (UN), including two mandates as UN Special Rapporteur. ${ }^{11}$ Writing from the perspective of both an academic and as Special Rapporteur, his views bear considerable weight within the human rights movement and regime. Therefore, Alston's take on the situation is paradigmatic for a much broader range of scholars, professionals, and activists. We thus believe that his view demands a closer scrutiny.

Alston identifies five key challenges in the era of populist backlash, which entail that human rights proponents need to rethink many of their assumptions, re-evaluate their strategies, and broaden their outreach' - albeit 'without giving up on the basic principles' of the movement. ${ }^{12}$ The first challenge is the populist threat to democracy and, in particular, the growing willingness to sacrifice individual and collective freedoms at the altar of security. The second challenge is about the shrinking space for civil society, which is not only diminishing rapidly, but has already been entirely closed in many parts of the world. The third challenge is to find ways to address the issues of inequality and exclusion more effectively. The fourth challenge concerns the undermining of the international rule of law, especially with regard to the use of force vis-a-vis the marginalisation of international humanitarian law. Finally, the fifth challenge regards the fragility of international institutions, many of which - included but not limited to the International Criminal Court, the Human Rights Committee, the European Court of Human Rights, and the InterAmerican Court of Human Rights - have come under immense pressure due to budget cuts, the withdrawing of some members, or the unresponsiveness of others when it comes to planned 'reforms' ${ }^{13}$

In response to such challenges, Alston suggests five strategies for addressing the perceived crisis. First, the human rights movement ought to develop better synergies between international and local human rights activism. Secondly, the human rights movement should include economic and social rights as important and authentic part of the overall human rights agenda. A third point is to broaden the outreach to identify new actors for cooperation, including corporations. Fourth, Alston advocates for new and more persuasive

\footnotetext{
11 Philip Alston was Special Rapporteur on Extrajudicial, Summary or Arbitrary Executions between 20042010; and he has held the office of UN Special Rapporteur on Extreme Poverty and Human Rights since 2014.

12 Alston, 'The Populist Challenge', p. 2.

${ }^{13}$ Ibid. pp. 4-8.
} 
communication strategies to more effectively engage both states and general public: instead of limiting its role to denouncing violations, the human rights movement could put forth less absolute arguments in order to structure a more prolific dialogue. Finally, Alston questions the benefits and scope of some critical scholarship, calling for a greater sense of responsibility on the part of human rights scholars. ${ }^{14}$

Alston's article has sparked a discussion which the present article also seeks to contribute to. For example, Vijay Nagaraj reflects on Alston's arguments through his experience with human rights protection in Sri Lanka. Nagaraj questions whether human rights have become too much of a language of 'law and other mechanisms of top-down authorization'; whether such embracement of procedures has brought advocates to lose their ability to speak of the idea of human rights 'as deriving from a deeper place, from a sense of relational ethics, love, compassion and solidarity'. ${ }^{15}$ Notably, Nagaraj acknowledges that human rights advocates in Sri Lanka have more or less ignored issues of economic harms and distributive injustices, many prominent activists believing that the human rights movement should focus on civil and political rights instead. This, Nagaraj seems to hint, could be due to the fact that the financial support for most human rights work in the country comes 'from the United States Agency for International Development (USAID) that is channelled through large for-profit contractors like Tetra Tech, Chemonics and others' for whom 'human rights is really just one more business'. ${ }^{16}$

In another response, Ron Dudai invites scholars to pay greater attention to the possible root causes of the populist backlash. For example, too little consideration is given to internal disillusionment, even though many of those who are 'ideologically aligned' with human rights values have grown increasingly frustrated with the inability of human rights institutions to 'deliver the goods' ${ }^{17}$ At the same time, the constant attempt to fit human rights into other frameworks, such as development or climate change, has also caused their

\footnotetext{
14 Ibid. pp. 8-13.

${ }^{15}$ Nagaraj, V.K., 'Human Rights and Populism: Some More Questions in Response to Philip Alston', Journal of Human Rights Practice, 9 (2017), 22-24. p.24

16 Ibid. 23.

${ }_{17}$ Dudai, R., 'Human Rights in the Populist Era: Mourn then (Re)Organize', Journal of Human Rights Practice, 9 (2017), 16-21, p.17.
} 
inflation and dilution. The lack of coherence might have made it easier for conservative and populist movements to hijack human rights language and causes. Not all problems are 'cultural' though. For instance, Dudai notes how new technologies have allowed almost anyone to document or claim possible human rights abuses, thus eroding the traditional role of human rights organizations. ${ }^{18}$ To confront these challenges, Dudai suggests that human rights organizations should rethinking the meaning of human rights activism tout court. In so doing, Dudai notes the difference between diplomatic forums such as Geneva and local activism, and argues that there is need to reconnect human rights with grassroots social movement and struggles so that human rights are not deployed in abstract discussions but to campaign against very concrete injustices. The rethink of the human rights platform and strategy ought to be particularly radical when it comes to economic and social rights; for Dudai, the time may have come to take a stronger stance against 'free markets' in favour of more effective forms of redistribution from the rich to the poor. ${ }^{19}$

Nagaraj and Dudai expose the two areas in which we believe Alston's intervention is perhaps incomplete. First, we agree with Dudai on the need for 'a more elaborate diagnosis' of the reasons of the 'current crisis' of human rights, ${ }^{20}$ for the polemical contention with populism might prove misleading. ${ }^{21}$ Secondly, we share with Nagaraj the sense that the bias and limits of the human rights regime and activism when it comes to economic and social rights runs deep, making Alston's envisioned solution potentially ineffective or at least insufficient.

Alston acknowledges that populism has been driven, at least in part, by legitimate sentiments for worsening economic conditions and rising inequality. He laments how mainstream human rights advocacy has addressed 'economic and social rights issues in a tokenistic manner at best, and the issue of inequality almost not at all' ${ }^{22}$ causing a loss of

\footnotetext{
${ }^{18} \mathrm{Ibid}$. 17-18. On the role of technology in human rights documentation, see also Gregory, S., 'Cameras Everywhere Revisited: How Digital Technologies and Social Media Aid and Inhibit Human Rights Documentation and Advocacy', Journal of Human Rights Practice, 11 (2019), 373-392.

${ }^{19}$ Dudai, 'Human Rights in the Populist Era', p. 19.

${ }^{20}$ Ibid. p. 17.

${ }_{21}$ Also addressed by Koskenniemi, M., 'Alston Rocking the Human Rights Boat: Reflections by a Fellow Passenger' (forthcoming).

22 Alston, 'The Populist Challenge', p. 6. See also UN Human Rights Council (2015), Report of the Special Rapporteur on extreme poverty and human rights, Philip Alston. A/HRC/29/31.
} 
faith in human rights. Indeed, many now feel 'they have no stake in the human rights enterprise' ${ }^{23}$ To counter the populist backlash, human rights actors must therefore give economic and social rights a more central role in the human rights agenda so as to address the concerns 'of those who feel badly done by as a result of what we loosely call globalization-driven economic change'24. As Alston points out, this means that 'human rights proponents need to start looking at budgets, at tax policy, and at fiscal policies in

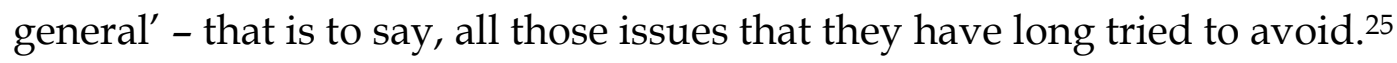

However, Alston's formula for harnessing human rights to tackle inequalities is less radical than it might sound. What is not needed, he warns, 'is to move the focus to the blight of poverty (...) or to the need for more resources for development'. For Alston fears that when 'the rights are conflated or confused with development, or poverty alleviation', the campaign starts to seem 'huge and overwhelming', thus further alienating states afraid of burdening costs. ${ }^{26}$ Instead, Alston suggests that the solution is to follow an existing and familiar path, that is, 'to follow the recipe that we have developed for civil and political rights promotion' in order to advance social and economic rights as well. ${ }^{27}$ Such 'recipe' is about recognition, institutionalisation, and accountability:

'We need to (...) start with legislative and other forms of recognition of a right (...). Next we need to build up specialized institutions which are going to promote the right in ways that are meaningful in that society. And finally, we need to build up accountability mechanisms'.28

As Alston puts it, 'in terms of these essential elements of recognition, institutionalisation, and accountability, economic and social rights are no different' from civil and political rights' ${ }^{29}$ Hence, it appears to us that Alston is advocating for doubling down on what has been the key program and strategy of the human rights movement since the 1970s.

\footnotetext{
${ }^{23}$ Alston, 'The Populist Challenge', p. 6

24 Ibid..

${ }^{25}$ Ibid. p. 10.

${ }^{26}$ Alston, 'The Populist Challenge', p. 9

27 Ibid.

28 Ibid.

29 Ibid.
} 
Alston is not alone in this 'doubling down' approach. In other recent contributions to the Journal of Human Rights and Practice, different scholars ultimately echo the very same strategy of doubling down. For example, Paul Gready defends the importance of human rights work even when success is uncertain and responses hostile because it is the right thing to do and because moral acts 'leave a trace, sow a seed'. 30 The challenge, as he sees it, lies mainly in communication: the human rights movement ought to spend more time and energy on being persuasive, on learning how to frame arguments, how to embed facts in compelling narratives about the future of society, and on rethinking solidarities without and within. ${ }^{31}$

In a different article, Mark Heywood also suggests that the way forward in promoting economic and social rights is to double down on the existing human rights platform. Heywood starts from a more drastic position than Alston, writing that the realization of socioeconomic rights under neoliberal forms of capitalist economy is perhaps impossible. He thus invites human rights scholars and advocates to show greater courage and willingness to address the question of who has control, who wields power. ${ }^{32}$ Furthermore, Heywood concedes to critics that human rights may have at times 'looked like a handmaiden to neoliberalism', for the forms of power and interest at play in capitalism found they have 'a self-interest in advancing human rights frameworks'. ${ }^{33}$

While Heywood's analysis is perhaps more radical than Alston's, his solutions are nonetheless remarkably similar. For Heywood provides a powerful defence of human rights, pointing out that they have 'achieved significant pro-poor reform in the last two decades', and that surrendering the framework would 'leave us much weaker in our fight for equality.' ${ }^{34}$ Indeed, if the human rights covenants have produced disappointing results, this is so, according to Heywood, primarily because the United Nations Treaty Bodies they

\footnotetext{
${ }^{30}$ Gready, P., 'Reflections on a Human Rights Decade, Near and Far', Journal of Human Rights Practice, 11 (2019), 422-437, p. 423. Gready draws from Shulman, D., 'On the Goodness of Despair', Journal of Human Rights Practice 6:3, (2014), 503-510.

${ }^{31}$ Gready. 'Reflections on a Human Rights Decade', 431-435.

32 Heywood, M., 'South Africa's Journey from Socialism to Human Rights: The True Confessions of an Errant Socialist', Journal of Human Rights Practice, 11 (2019), 305-323, p. 318

${ }^{33}$ Ibid. 317.

34 Ibid.
} 
produced 'have not yet been effectively utilized by civil society to demand their enforcement as global standards'. ${ }^{35}$ Therefore, Heywood believes in doubling down on the existing human rights project and institutions, too.

The general consensus for doubling down on the existing human rights platform is married with a twofold appeal: human rights activism ought to find better ways of communicating and also be more pragmatic. In practice, this approach translates into reviving the legal potential of the United Nations' International Convention on Economic, Social, and Cultural Rights (ICESCR). Indeed, both Alston's and Heywood's arguments point to Olivier de Schutter's work against regressive socio-economic measures. Indeed, de Schutter notes that most states have already ratified the ICESCR, but argues that they enjoy excessive discretion in implementing it. The problem, as he sees it, is one of accountability and therefore justiciability of economic and social rights. To counter such problem, de Schutter claims that both regressive policies and non-implementation amount to violations of the Convention. ${ }^{36}$ As economic and social rights are already recognised and enshrined within a legally binding convention, the human rights movement should focus on greater institutionalisation and accountability, thus becoming more vigilant and capable of evaluating economic and fiscal policies to ensure the state compliance to its core obligations.

There is great merit to de Schutter's approach. There are some relative risks, too. For example, expanding the 'recognition, institutionalisation, and accountability' strategy to economic and social rights in the way Alston, Heywood, and de Schutter envision is likely to also double down on that culture of expertise that has come under scrutiny and has been the target of populist attacks. For holding states accountable on the economic and social obligations can only translate in greater demand for new types of international expertise. The struggle thus becomes one between the alleged moral primacy of human rights and technical neutrality of international bureaucracies versus the 'politics' of populist movements. The implied danger is therefore that of fuelling rather than defusing populism. This perhaps superficial example about expertise suggests that Alston's grievance against

\footnotetext{
35 Ibid. 318.

${ }^{36}$ De Schutter, O., The Rights-Based Welfare State: Public Budgets and Economic and Social Rights, Friedrich Ebert Stiftung, 2018, p. 3, 9.
} 
'destructive and irresponsible' critical scholarship is perhaps short-sighted. ${ }^{37}$ As Martti Koskenniemi puts it, 'taking a break from criticism of human rights (...) is not likely to strengthen them' either, for the present problems of the movement are less a consequence of critical scholarship and more 'by the intellectual autism of human rights culture' ${ }^{38}$

The present article indeed responds to the calls of both Dudai and Koskenniemi, for 'more awareness is needed about what the "backlash" stands for and what might be needed in response to it'. ${ }^{39} \mathrm{~A}$ more attentive analysis of the current threat means identifying the actual problems and challenges so to provide more effective strategies. We want to question whether, if 'the challenges ... are fundamentally different', the most effective strategy is to really double down on the existing recipe. For instance, such view avoids confronting uncomfortable demands on how human rights may have contributed to the existing discontent. Doubling down on the human rights program without first understanding its entanglement with the world could prove both ideological and risky, as it might turn into a doubling down on errors and regrettable mistakes. Therefore, our intent is not that of contesting Alston, but rather that of broadening the scope and terms of the current debate about and around the threats of populism and the ability of human rights to engage with issues of inequalities.

\section{Human Rights and Populism}

Although the main focus of this article is on Alston's call to double down on the existing human rights project to address material inequality, we agree with Dudai that addressing that problem requires some more conceptual clarity regarding the so-called crisis of human rights, for such clarity may help assess the steps that are needed to reorient the human rights movement. In seeking to provide more elaborate conceptual lenses through which to view the 'crisis', we wish to question whether presenting human rights and populism as antagonistic opposites to each other is the best possible path forward.

\footnotetext{
${ }^{37}$ Dudai, “Human Rights in the Populist Era', pp.19-20. See also, Sharp D.N., 'Through a Glass, Darkly: Three Important Conversations for Human Rights Professionals', Journal of Human Rights Practice, 11 (2019), 296-304, pp. 299-300.

${ }^{38}$ Koskenniemi, 'Alston Rocking the Human Rights Boat'.

${ }^{39}$ Ibid.
} 
As Alston writes, echoing many similar voices, 'the populist agenda that has made such dramatic inroads recently is (...) explicitly antagonistic to all or much of the human rights agenda'. ${ }^{40}$ But although Alston has good reasons for this statement, this section argues that viewing populism as the antagonist of human rights might ultimately prove misleading. ${ }^{41}$ In so doing, the section makes two points: first, populism ought to be understood not as an agenda but as a tactic or a tool; and secondly, the actual challenge to human rights is thus not populism as such, but how nationalist uses of populist tactics are eroding the democratic fabric of liberal states on the two shores of the North Atlantic and beyond.

As we argue, shifting the focus on nationalism might help reorient the human rights movement. For much like populism, nationalism is also far from a monolithic entity. At least in Western states, nationalist populism has taken two very damaging forms. Firstly, populist rhetoric has been used to exclude various 'others' from asylum seekers to minorities. Secondly, and importantly for this article, it has also been used to justify drastic economic projects, such as the kinds of tax 'reforms', which have turned out to be mostly tax cuts that benefit large corporations and shareholders. ${ }^{42}$ However, in addition to these destructive forms, there is also a positive element to nationalism - one which perhaps has appealed to the public but which has been entirely ignored in the contemporary populist practices. This element is solidarity, which is the forgotten term from the revolutionary triad 'freedom, equality, solidarity'. As we argue, returning solidarity to its place of honour may help reprogram the human rights movement and gain back some ground that it has lost to nationalist populism.

\section{3..1 On Populism...}

\footnotetext{
40 Ibid. p. 1.

41 This antagonism echoes Oakeshott, M., The Politics of Faith and the Politics of Scepticism, Yale University Press, 1996 (arguing that democracy is a dialectic between two forces, faith and scepticism). Populist movements would embody the politics of faith, whereas human rights and their resistance would embrace the politics of scepticism.

42 See, for the United States, the Tax Cut and Jobs Act ("An Act to provide for reconciliation pursuant to titles II and $\mathrm{V}$ of the concurrent resolution on the budget for fiscal year 2018'), Public Law No. 115-97, 2017. Read further, August, J.D., 'Tax Cuts and Jobs Act of 2017 Introduces Major Reforms to the International Taxation of U.S. Corporations', The Practical Tax Lawyer, 32:2 (2018), 43-54.
} 
One has to be careful when discussing populism - especially in the international context for there are so many modes of it, from conservative to progressive and right-wing to leftwing versions. ${ }^{43}$ Nevertheless, there are some elements that at least most versions have in common. Whether one intends it as ideology, discourse, or strategy, populism is about seizing power - most notably, state power. Populism does not have any substantive government program of its own because it is mostly a tactic to occupy the state via the formally regular course of democratic processes. ${ }^{44}$ Indeed, populist leaders run in the general elections, often through the very party system they ultimately undermine. They seduce voters with bombastic rhetoric and the lure of untenable promises, the realisation of which is often made dependant on the preliminary defeat of some real or imaginary 'enemy', thus exacerbating divisions and conflicts in society. Once in government, many populist movements display remarkably authoritarian traits: in face of poor performances in delivering on any such promise, the frequent populist response is to blame some internal or external 'enemy'. ${ }^{45}$ This could be a foreign government allegedly interfering with internal affairs, some minority conspiring against the people and the state, or even the so-called 'deep state' 46 that supposedly hinders the otherwise effective action of the government with rules and procedures, thus offering additional momentum to push back on checks and balances. The rhetorical use of the more or less invisible enemies further allows populist leaders to assert a monopoly in speaking for 'the people'. ${ }^{47}$ Hence, populist leaders and movements can steer negative sentiments of a purported majority to seek an even stronger mandate through new elections, ultimately transforming the political life of a country into an endless electoral campaign. ${ }^{48}$

\footnotetext{
${ }^{43}$ For an overview of different theories and interpretations, Anselmi, M., Populism: An Introduction, Taylor and Francis, 2017.

${ }^{44}$ Populism has been also intended as 'political style' or 'performance', see, Moffitt, B., The Global Rise of Populism: Performance, Political Style, and Representation, Stanford University Press, 2016 (pointing to the role of technology as contributing to the success of populism. New digital platforms offer political leaders or representatives a way to communicate 'directly' with their supporters).

${ }^{45}$ This strategy is carefully described in Jünger, E., Der Waldgang, Klett-Cotta, 1986 (detailing the Nazi strategy of growing consensus while justifying failures by producing internal and external enemies).

${ }^{46}$ E.g., Santos, R., The Deep State, Greenhaven Publishing, 2018 (focusing on the military industry and apparatus). The deep state is largely regarded as one of the many 'conspiracy theories' of contemporary politics. It is a way to refer to unelected bureaucrats that use their authority and prerogatives to trump political decision making in order to advance personal agendas.

47 Müller, J.-W., What Is Populism?, University of Pennsylvania Press, 2016 (arguing that contemporary populism represents a cultural reaction to pluralism).

${ }^{48}$ A phenomenon that has become intrinsic to American democracy (see, Lexington, 'The Endless Campaign', The Economist, August 27th 2001), but has intensified and spread to other Western democracies.
} 
Taken this way, populism is a 'malady' of liberal democracies - a 'malady' primarily affecting the way some political groups organise and strategize to seize and retain state power. ${ }^{49}$ Therefore, this 'disease' affects multi-party democracies when existing political parties fail to renovate and grow distance from their voters, especially in times of economic crisis. Surfing the discontent and appealing on the perceived self-referentiality of political parties and state bureaucrats, populist leaders often win support from voters presenting themselves as statesmen ready to 'drain the swamp'. ${ }^{50}$ Indeed, another common feature of populist movements is to assert their moral primacy over other, allegedly corrupt, groups. However, once installed into office, populist leaders or movements display a preference for loyalty over competence (i.e., 'clientelism'), 51 the inclination towards forms of protectionism (to acquire and reward clients), an idiosyncratic understanding of security, and so forth, thus exacerbating those negative features they were meant to fight. Largely centred on the charismatic figure of a leader, populist movements tend to unsettle the traditional division of powers, often marginalising the legislative branch at the advantage of the executive.

What these considerations of common features of populist movements in the context of party politics exposes is that populism is most of all a tactic to gain power for seizing, retaining, concentrating, or eventually displacing institutional power - or eventually a tool to exercise power. Populism is therefore not so much a matter of substance, but of form. Indeed, although liberal by heart, the human rights movement, too, has on occasion adopted tactics that might be regarded as populist. One such examples is 'naming and shaming', a media pillory aimed at galvanising the sentiments of people to provide strength and legitimacy to a cause or campaign against a given practice or government. ${ }^{52}$ Naming and shaming can steer strong emotions and it often results in an ideological 'war of trenches',

\footnotetext{
49 The idea of 'malady' is borrowed from Revelli, M., Populismo 2.0 (Populism 2.0), Einaudi, 2017.

50 The expression has become frequent under US President Donald Trump. Cf. inter alia, (pro), Douthat, R., 'Under Trump, the Swamp is Draining', The New York Times, December 1st, 2018; (contra), Olen, H., 'Trump Didn't Drain the Swamp. Supporters Are Starting to Notice', Washington Post, September 11 th, 2018.

${ }^{51}$ For an analysis of the widespread phenomenon, Stokes, S., Political Clientelism, Oxford University Press, 2011.

52 There is a vast literature both in favor and critical to the practice. For a broader account in the general practice of international relations, Friman, H., The Politics of Leverage in International Relations: Name, Shame, and Sanction, Palgrave Macmillan, 2015. On the limits of 'naming and shaming', Domínguez-Redondo, E., 'The Universal Periodic Review -- Is There Life Beyond Naming and Shaming in Human Rights Implementation?', New Zealand Law Review, 4 (2012), 673-721.
} 
that is: 'us versus them', 'victims versus perpetrators'. ${ }^{33}$ Similarly, human rights actors have enhanced their power through what could be regarded as populist tool: just like populist movements claim to speak for 'the people' as a whole, human rights claim to be acting in the name of 'humanity'. ${ }^{54}$

Speaking on behalf of either the people or humanity is a rhetorical populist tactic to enhance the sense of legitimacy, which often allows passing and/or disguising unpopular measures. ${ }^{55}$ For example, populist movements across the Western hemisphere have been successful in leveraging the discontent of the uncompensated losers of the increasingly sophisticated mechanisms of the political economy of the world. But the discontent of increasingly struggling workers, either unemployed or underpaid, has been used to promote protectionist trade tariffs at the advantage of national businesses. The frustration of a disappearing middle class has served to pass tax 'reforms', that is, tax cuts that benefitted mostly corporations and shareholders. ${ }^{56}$ In other words, populist tactics and tools are designed to serve particular agendas of those in power. In that, populism is certainly a very important red flag, an indicator that should no doubt attract the attention of the human rights movement. However, the risk is to engage with populism as if populist tactics were themselves the problem, as if the problem was one of form and/or procedures rather than actual substance. Instead, it is crucial to engage with the particular agenda that makes use of populist tactics. It seems plausible to suggest that the main agenda behind populist

\footnotetext{
53 Meister, R., 'Human Rights and the Politics of Victimhood', Ethics and International Affairs, 16:2 (2002), 91-108 (victimhood is functional to de-politicisation and it generates polarisation and resentment, thus paving the way for more conflictuality). More comprehensively, Simonsen, K., \& Kjærgård, J. (eds.), Discursive Framings of Human Rights: Negotiating Agency and Victimhood, Birkbeck Law Press, 2017.

${ }^{54}$ Inherent in this shared stance is the sense of moral superiority. Cf. Beitz, C., 'Human Rights as a Common Concern' American Political Science Review, 95:2 (2001), 269-282 (human rights as standard to evaluate governments and institutions). Beitz embraces the view for which human rights are de facto a global moral standard, which implicitly requires moving from an assumption of self-proclaimed moral superiority.

${ }^{55}$ Human rights and populist movements equally promise to vindicate the powerlessness of individuals, groups, and peoples against perceived injustices. Where they might differ, depending on the populist movement in question, is in identifying victims and injustices: for example, while human rights organization rightly side with the thousands of migrants crossing the Mediterranean Sea, the leader of the Italian populist movement Lega Nord presented Italian citizens as victims of migration.

56 See, for the United States, the Tax Cut and Jobs Act ('An Act to provide for reconciliation pursuant to titles II and V of the concurrent resolution on the budget for fiscal year 2018'), Public Law No. 115-97, 2017. Read further, August, J.D., 'Tax Cuts and Jobs Act of 2017 Introduces Major Reforms to the International Taxation of U.S. Corporations', The Practical Tax Lawyer, 32:2 (2018), 43-54.
} 
movements, on both the left and the right, is largely nationalist. Therefore, the challenge is less about populism as such than it is about nationalism.

\section{2... and on Nationalism}

The issue that human rights scholars and advocates have with the prevailing political atmosphere cannot be just about populism per se. Rather, it seems that the issue is the substance of most current populist movements, namely nationalism. Indeed, human rights seem to be more antagonistic to nationalism - or at least some "deviant" versions of it - than they are to the empty form of populism. Although human rights cannot avoid a certain degree of entanglement with nationalism, for example in promoting self-determination, much of the history and institutional development of contemporary human rights is intertwined with curbing the potential brutality of nationalism and the nation state. In other words, the tension arises when nationalist rhetoric and programs drift into authoritarianism, fuelling social resentment, xenophobia, or even persecution, as happens in the current environment where human rights are needed in their original function in protecting minorities that nationalist rhetoric villainises. ${ }^{57}$

Nationalism is hardly a homogenous phenomenon, however. Just like for populism, the range and variety of nationalist movements is broad, as it includes people situated along the whole political spectrum, from right to left. ${ }^{58}$ Mapping the whole spectrum of contemporary nationalist movements and agendas is beyond the scope of the present work. The aim of this part is to question how nationalist narratives have become more persuasive and appealing than human rights. One possible answer is that human rights do not offer effective enough answers to some of the anxieties and preoccupations people confront in their daily lives. Here we encounter an issue raised by Nagaraj and Dudai in their responses to Alston. For the human rights enterprise and movement have become highly

\footnotetext{
${ }^{57}$ A first wave of international human rights instruments after World War II was designed to ensure protection to national minorities against the abuses of governments. This was indeed the basis for the Convention on the Prevention and Punishment of the Crime of Genocide, United Nations, 1948. See, Vrdoljak, A.F., 'Human Rights and Genocide: The Work of Lauterpacht and Lemkin in Modern International Law', European Journal of International Law, Vol. 20:4 (2009), 1163-1194.

58 Similarly problematizing but also defending the usefulness of 'populism' as comprehensive analytical category, Brubaker, R., 'Why Populism?', Theory \& Society, 46:5 (2017), 357-385.
} 
bureaucratised and embedded within the very system they were supposed to contest. Human rights advocates have been used to speak truth to power, 59 but to the dismay of some activists, the human rights movement is today associated with those very elites that have become target of relentless criticism. Human rights are accused of being a regime of governance, an expert language translating vague political agendas into administrative goals, for which human rights experts negotiate, measure, and monitor the progresses of a sophisticated but self-referential international bureaucracy. ${ }^{60}$

The embeddedness is problematic for at least three reasons. First, the human rights movement has traditionally regarded itself as external to power, thus escaping accountability. Secondly, as the embeddedness is also cultural, there is a further bias in favour of measures or solutions that double down on the existing system and ideology. ${ }^{61}$ Finally, a position of embeddedness makes it more challenging to answer Dudai's call to explore and understand the root causes of a widening popular discontent, which ultimately results in growing support for nationalist platforms. The risk is for the human rights movement to engage into an ideological struggle to reaffirm the moral high ground of human rights against nationalist agendas. Although there is merit to that battle, it would fail to duly explore the reason why of nationalism, thus ignoring the anxieties and preoccupations of the very people the human rights movement aspires to speak for.

One reason why nationalisms might appeal to large parts of the population throughout the Western hemisphere is that they promise those forms of belonging and internal solidarity that globalisation has progressively eroded. In perhaps different ways, nationalist platforms

\footnotetext{
${ }^{59}$ Kennedy, Dark Side of Virtue, p. xvi. For a collection of stories on human rights activism, Kennedy, K., Adams, E., \& Richardson, N., Speak Truth to Power: Human Rights Defenders Who Are Changing Our World, Umbrage Editions, 2005.

${ }^{60}$ For a broader critique of international expertise (not limited to human rights), Easterly, W., The Tyranny of Experts: Economists, Dictators, and the Forgotten Rights of the Poor, Basic Books, 2013.

${ }^{61}$ From climate change to inequalities, the answers they often provide often consist of simply doubling down on existing systems. For example, at the 2019 Davos meeting, the envisioned solutions were 'more technology' and 'better education'. Long, H., '"The Aristocrats Are Out of Touch": Davos Elites Believe the Answer to Inequality is Upskilling', The Washington Post, January $26^{\text {th }}$, 2019. A summary of the main theme discussed at the forum is available on their website: www.weforum.org/focus/davos-2019 (last access, August $7^{\text {th }}$, 2019). UNICEF rephrased business 'non-solutions' as if they were the youth's actual demands. UNICEF, 'Young People to Davos: More Jobs, Better Education', Press Release, January 21st, 2019. Available at: www.unicef.org/press-releases/young-people-davos-leaders-more-jobs-better-education (last access, August $7^{\text {th }}$ 2019).
} 
on both the left and the right put particular stress on the idea of belonging, on identity. However, they also play identity against solidarity. Nationalist movements have confined and thus displaced the role of solidarity by linking it to the mere assistance to migrants and refugees. At the same time, governments have been outsourcing solidarity to private initiatives, causing civil society to become more and more dependent on philanthropy (i.e., philanthropic capitalism). ${ }^{62}$ Therefore, the identitarian argument of the nation is used today not to empower institutions and enhance forms of solidarity between members of the same community, 63 what is normally referred to as 'patriotism', 64 but instead to undo large portions of the welfare state and to enable a militarised form of territoriality to contrast alleged 'invasions' of undeserving migrants. That is, nationalist movements are deliberately attacking statehood and the entailed principle of solidarity. ${ }^{65}$

Nationalist movements are using populist struggles to take over the state with the apparent aim of undoing it. On the one hand, migration is mixed with terrorism in order to justify an increase in spending on military, police, and surveillance. On the other, migration also offers an argument to cut back on welfare provisions. At a deeper level, the objective appears that of dissolving the public sphere and its guarantees in order to unleash private forms of power - a remarkably regressive trend that goes to show that no social or political achievement should ever be taken for granted. The struggle is thus about the typology of the state: a minimalist and perhaps authoritarian 'nocturne guardian' or a welfarist state? Solidarity

\footnotetext{
62 See, e.g., Gaudiani, C., The Greater Good: How Philanthropy Drives the American Economy and Can Save Capitalism, Henry Holt, 2003; similarly, Bishop, M., \& Green, M., Philanthro-Capitalism: How the Rich Can Save the World, Bloomsbury Press, 2008 (arguing philanthropy is not charity but a form of social investment that can improve capitalism further). Ács, Z., Why Philanthropy Matters: How the Wealthy Give, and What It Means for Our Economic Well-Being, Princeton University Press, 2013 (suggesting the role of philanthropy is underestimated. It implicitly accepts that philanthropic capitalism is an American ideology increasingly spread on a global scale). 'Philanthropic capitalism' has been criticised for establishing forms of dominance, dependency, and pseudo-colonialism, Wilson, J., 'Fantasy Machine: Philanthrocapitalism as an Ideological Formation', Third World Quarterly, 35:7 (2014), 1144-1161; and for creating dysfunctional responses, especially when it comes to public health, inter alia, Clark, J. \& Mcgoey, L., 'The Black Box Warning on Philanthrocapitalism', The Lancet, 38:19 (2016), 2457-2459.

${ }^{63}$ Anderson, B., Imagined Communities: Reflections on the Origin and Spread of Nationalism, Verso, 2016. One interesting shift has been that of locating solidarity at the global level, antagonistically leveraging solidarity against nations. See, e.g., Goodman, J. \& James, P., Nationalism and Global Solidarities: Alternative Projections to Neoliberal Globalisation, Routledge, 2007.

${ }^{6}$ Cf. Murray, J., 'Nationalism, Patriotism, and New Subjects of Ideological Hegemony', Journal of Philosophy, 6:14 (2011), 16-30.

${ }^{65}$ On the synergies and tensions between contemporary nationalism and neoliberalism, Harmes, A.,'The Rise of Neoliberal Nationalism', Review of International Political Economy, 19:1 (2012), 59-86.
} 
(which is just another name for 'brotherhood') is the forgotten term from the revolutionary triad 'freedom, equality, solidarity'. Hence, the human rights movement could reappropriate the notion of solidarity to vindicate its original promise. To the extent nationalist movements are today undermining social welfare and replacing internal solidary with its boorish surrogate, that is, xenophobia, then human rights are better placed to promote a program that aims to re-establish solidarity relations between people within and beyond their national communities.

The widespread use of populist tactic to revive nationalist themes exposes an ongoing struggle to assert or consolidate dominance. The human rights movement needs to accept and embrace its position and role in a field of struggles - struggles that are political in nature, something that human rights proponents have been fairly reluctant to acknowledge. ${ }^{66}$ The human rights project does not consist of self-evident universal truths, but it rather pursues specific political interests that inevitably clash with those of others. Privileges of whatever nature are never given up without significant resistance and thus socio-political struggles. ${ }^{67}$ But many in the human rights movement hardly see themselves as actors seeking or leveraging power; ${ }^{68}$ instead, they have adopted a position of 'watchdogs', 69 which ultimately betrays a certain degree of embeddedness within the very system they should challenge.

\section{Human Rights and the Political Economy of the World}

The previous section argued that a path forward for the human rights movement, and a possibility of gaining back lost ground from nationalist populist, may be to return the notion

\footnotetext{
${ }^{66}$ Kennedy, Dark Side of Virtue, p. xvi et passim.

${ }^{67}$ For an interesting account on inequalities throughout history, see, Scheidel, W., The Great Leveler: Violence and the History of Inequality from the Stone Age to the Twenty-First Century, Princeton University Press, 2017 (arguing that inequalities have historically decreased after wars, revolutions, dissolution of civilizations, and pandemics, which often occurred because of resistance to reforms for better wealth redistribution).

68 Koskenniemi, 'Alston Rocking the Human Rights Boat'

69 See, Risse, K.T., Ropp, C.S. \& Sikkink, K. (eds.), The Persistent Power of Human Rights: From Commitment to Compliance, Cambridge University Press, 2013 (the volume contains a number of interventions that track the transformation of human rights from grassroots advocacy to compliance and accountability).
} 
of solidarity to its position of prominence within the movement. We will return to this theme in the concluding section of the article. Before that, however, there is another point that has to be made to complete the picture. For although we argued above that the true antagonistic opponent of the human rights movement might be nationalism, rather than populism per se, it is worth noting that states and governments play today only partial functions within a broader political economy of the world. Prophets of globalisation have used this to suggest that nation states - and perhaps statehood as such - are doomed to fade. But while states have been progressively emptied of their political significance, they have not disappeared. They have been turned into security devices to protect private property, international investments, and other interests. ${ }^{70}$ For the postcolonial world has bypassed sovereign equality through a political economy that fundamentally perpetuates patterns of dominance.

In thinking about the role of potential of human rights in the context of this material reality, Alston is once again a useful interlocutor. As discussed in Section 2, Alston suggests that there could be a straightforward remedy to this situation, namely to more robustly include social and economic rights in the human rights programme. Alston thus invites human rights advocates to double down on a consolidated recipe: recognition, institutionalisation, and accountability. ${ }^{71}$ Alston's intervention is important because he is certainly correct to point out that social and economic rights have been for long marginalised for the most diverse reasons. ${ }^{72}$ Perhaps most importantly, many have been content with a mere promise of 'progressive realisation' that never quite materialised, social and economic rights having been labelled as more expensive and more difficult to both realise and enforce, compared to civil and political rights. ${ }^{73}$ Unsurprisingly, then, towards the end of the Millennium, a

\footnotetext{
${ }^{70}$ Kennedy, D., 'Law and the Political Economy of the World', Leiden Journal of International Law, 26:1 (2013), 7-48.

${ }^{71}$ This is also the view of Sikkink, K., The Justice Cascade: How Human Rights Prosecutions Are Changing World Politics, W.W. Norton \& Co., 2011. More recently, Sikkink, K., Evidence for Hope: Making Human Rights Work in the 21 $1^{\text {st }}$ Century, Princeton University Press, 2017.

72 Their status as actual rights has been put under question. See, Cranston, M., "Human Rights: Real and Supposed", in Raphael, D.D. (ed.), Political Theory and the Rights of Man, Indiana University Press, 1967, pp. 4351; Cranston, M., 'Are There Any Human Rights?', Daedalus, 112:4 (1983), 1-17.

${ }^{73}$ On the attempts, failures, and successes of economic and social rights in reshaping the postcolonial world, Wills, J., Contesting World Order? Socioeconomic Rights and Global Justice Movements, Cambridge University Press, 2017 (the account lean more towards the future potential than effective success in the past).
} 
general frustration with the ineffectiveness of human rights to deliver on material needs brought countries from the global South to switch focus onto development. ${ }^{74}$

Where we disagree with Alston, however, is in his proposition that doubling down on the existing human rights project, but with extra attention on economic and social rights, is the best path forward. This is so for at least two reasons. First, human rights have become embedded in the political economy of the world: without sorting out their entanglement first, there is the risk of achieving the opposite end to the one allegedly sought. The second is the unwillingness or, more worryingly, inability on the part of the human rights movement to engage with the complexity and sophistication of the political economy of the world. The present Section thus discusses two problems: 'helplessness' and 'complicity'. While international lawyers have been paying greater attention to the significance of political economy and the role of international law in it, human rights have yet to seriously engage with this area. This Section aims to provide an initial input to what should possibly become a more widespread research agenda.

\subsection{The 'Helplessness' Problem}

In contemporary societies, matters of distribution and redistribution are incredibly complex; ${ }^{75}$ different narratives tend to reduce the problem to one or the other cause, often on the basis of some underlying ideological view. ${ }^{76}$ The increasing sophistication of the political economy of the world requires human rights to engage with technical aspects of law and their socio-economic impacts. But are human rights properly equipped for the task? Or to put it differently, is giving a more prominent role to social and economic rights, but

\footnotetext{
74 The relation between human rights and development has become a field of its own. As an introduction, inter alia, Langford, M., Sumner, A. \& Ely Yamin, A. (eds.), The Millennium Development Goals and Human Rights: Past, Present and Future, Cambridge University Press, 2013.

${ }^{75}$ For an introduction, see, Galbrath, J.K., Inequality: What Everyone Needs to Know, Oxford University Press, 2016. For Galbrath, there are two fundamental issues: first, the realisation that 'wealth is power' - and wealth is not just about income (p. 151); second, political institutions 'remain a bulwark against inequalities' (p. 111). 76 For example, referring to the U.S. political landscape, Jonathan Rothwell claims that the Left blames corporations while the Right points at unfair trade practices (and in times of populism, often times the arguments switch from one aisle to the other). Instead, he argues that the problem lies in the monopolization of key services. In this respect, it's unclear why he regards the Left's revived interest for antitrust as a limit. Cf. Rothwell, J., A Republic of Equals: A Manifesto for a Just Society, Princeton University Press, 2019. Rothwell also notes that the problem lies less in inequalities as such than in what society at large perceives as 'unfair' inequalities.
} 
otherwise doubling down on the existing project enough? Relative distribution and redistribution of wealth both within and among countries have traditionally been determined by at least four elements, namely: taxes, labour, trade, and prices. The problem is here twofold. On the one hand, these instruments are today largely ineffective in generating distribution and redistribution because they have been appropriated for achieving the diametrically opposite aims, that is, extraction of gains and concentration of wealth. On the other hand, human rights appear 'helpless' in this regard, for the human rights agenda rarely tackles any of such issues.

(a) Until very recently, human rights seemed to have little or nothing to say about taxes. ${ }^{77}$ Recent 'tax reforms' - that is, tax cuts for corporations and the wealthiest - have boosted buy-backs and dividends. But while stock markets have soared at record levels, ${ }^{78}$ wages have been stagnant ${ }^{79}$ despite several Western countries register increased productivity and some of the lowest unemployment rates since at least the 2007-2008 financial crisis. ${ }^{80}$ In other words, people work more (and more productively) to earn less. ${ }^{81}$ The contrast between financial gains and waged labour is of great importance. As Thomas Piketty has shown at length, one key cause - if not the key cause - of inequality has for centuries been the disparity in ownership of financial assets. The return on capital has been steadily higher than the return on paid labour. ${ }^{82}$ While there are proposals to impose

\footnotetext{
77 Until recently, literature in this area was scarce. The theme has been nonetheless gaining momentum in recent years. See, Beckett, P., Tax Havens and International Human Rights, Routledge, 2018; Alston, P. \& Reisch, N. (eds.), Tax, Inequality, and Human Rights, Oxford University Press, 2019.

${ }^{78}$ Egan, M., 'Market Milestone: This Is the Longest Bull Run in History', CNN Business, August 22nd, 2018. Also, Holmes, F. \& Great Speculation, 'Can the Bull Market Run Another 10 Years?', Forbes, March 7th, 2019.

${ }^{79}$ Limitedly to the United States, Mishel, L., Gould, E. \& Bivens, J., 'Report: Wage Stagnation in Nine Charts', Economic Policy Institute, January $6^{\text {th }}, 2015$. See also, Organization for Economic Cooperation and Development, Employment Outlook 2019: The Future of Work, OECD, 2019 (noting that unemployment has become less of an issue than stagnating wages). More recently, Stiglitz, J., 'Progressive Capitalism Is Not an Oxymoron', New York Times, April 19th 2019 . The theme is nonetheless controversial, as more liberal outlets contends the indicators and measures adopted to determine wage stagnation are misleading. Inter alia, Strain, M., 'The Story of Stagnating Wages Was Mostly Wrong', Bloomberg, May 15th, 2019; Gramm, P. \& Early, J., 'The Myth of "Wage Stagnation"', The Wall Street Journal, May 19th, 2019.

${ }^{80}$ For the United States, refer to the Employment Situation Survey by the Bureau of Labour Statistics at https://www.bls.gov/news.release/empsit.nr0.htm (last access, August 7th, 2019). For the European Union, data on employment are available on Eurostat at https://ec.europa.eu/eurostat/statisticsexplained/index.php/Unemployment_statistics (last access, August $7^{\text {th }}$, 2019).

81 To this point, one should further add the effects of automation and robotization. A recent proposal calls for taxing the work of machines. Cf. Rubin, R., 'The "Robot Tax" Debate Heats Up', The Wall Street Journal, January $8^{\text {th }}, 2020$.

82 Piketty, Capital in the Twenty-First Century. Those who own financial assets have been enjoying growing capital gains, whereas workers have suffered a progressive erosion of their wages. Financial assets are also
} 
taxes on financial transactions, ${ }^{83}$ there are currently only minor taxes on capital gain when taxation applies at all, for double taxation loopholes or tax minimisation strategies often allow to avoid taxes entirely. ${ }^{84}$ Furthermore, as inheritance taxes are either lifted or eluded in several rich countries, the result is a progressive concentration of wealth over time. ${ }^{85}$ In contrast, workers are today excluded from acquiring property once accessible to many, such as homes and cars; instead, higher prices, limited access to credit, and new market structures force workers into renting or leasing, for which they never acquire assets or equity. As Katharina Pistor has recently noted ${ }^{86}$ financial assets are pure legal creations: they do not exist without law - a law backed by a state willing and able to enforce it. It is thus curious how states are today effective in enforcing the set of contracts and other legal devices supporting the operations of financial markets, but seem unable to impose appropriate taxation on them. It is also interesting to note how firms and corporations have significantly improved the ability of states to tax labour and income, ${ }^{87}$ how states have repeatedly designed fiscal advantages, such as tariffs, to protect national firms and businesses, but for some reason the widespread belief is that states struggle to tax large transnational corporations. Insofar, the human rights movement has neglected the field of taxation. But taxes and rights are the fundamental skeleton of any state, for they decide the fundamental distribution of power and opportunities. As Alston and Reisch have recently noted: 'both taxation and human

tied up with collaterals, that is, with material assets (and vice versa). Hence, finance can leverage material wealth as well as expand it significantly.

${ }^{83}$ A first proposal was advanced by James Tobin, which has originated the name of 'Tobin Tax'. See, Tobin, J., 'A Proposal for International Monetary Reform' Eastern Economic Journal, 4:3/4 (1978), 153-159; reprinted, Tobin, J., 'A Proposal for Monetary Reform', Eastern Economic Journal, 29:4 (2013), 519-526.

84 The proposal for a tax on financial transactions, first put forward by the European Commission in 2011, is now gaining new traction because of the impact of high-frequency trading on security markets. See, Chung, K.H. \& Lee, A.J., 'High-Frequency Trading: Review of the Literature and Regulatory Initiatives Around the World', Asia-Pacific Journal of Financial Studies, 45:1 (2016), 7-33. Traditionally reluctant actors are more willing to accept a levy, which is presented as making markets more efficient while contributing to social justice, e.g., Buckley, R.P., 'Introducing a 0.05\% Financial Transactions Tax as an Instrument of Global Justice and Market Efficiency', Asian Journal of International Law, 4:1 (2014), 153-167.

85 Wagner, R., Death and Taxes: Some Perspectives on Inheritance, Inequality, and Progressive Taxation, American Enterprise Institute for Public Policy Research, 1973. More recently, Beckert, J., Inherited Wealth, Princeton University Press, 2008.

86 Pistor, K., The Code of Capital: How the Law Creates Wealth and Inequality, Princeton University Press, 2019.

87 Braithwaite, J., Regulatory Capitalism: How It Works, Ideas for Making It Work Better, Edward Elgar, 2008, pp. 23-24. Braithwaite describes the corporatization of the capitalist economy, suggesting how: 'one effect of the corporatization of capitalism in the twentieth century was that it made it easier for the state to collect taxes'. The contrast between corporate capitalism and middle-class capitalism is one of the themes dominating the contemporary political debate in the democratic primaries. See, e.g., The Economist, 'Elizabeth Warren Wants to Remake American Capitalism', The Economist, October 24th 2019. 
rights law are, in their essence, about the relationship between the individual and the state $^{\prime 88}$ Their recent volume is a fundamental first step, as it acknowledges the fundamental interconnection between taxes and human rights in at least two respects: first, taxes should allow a relative redistribution of wealth, rather than income, thus limiting social marginalisation and exclusion; second, tax revenues are essential to finance those infrastructures and services that states are called to put in place in order to realise positive and negative human rights obligations. ${ }^{89}$ Alston and Reisch argue that 'tax and human rights are inherently intertwined and face a common challenge today: the reconceptualization of what constitutes a just society and the social good'. ${ }^{90}$ Their analysis engages with the liberal debate on whether civil rights or taxes are more effective in redistributing wealth and power in society, ${ }^{91}$ for taxes imply a greater role for the state, whereas rights should leave broader margin to private initiatives. Alston and Reisch do challenge the growing trend of 'privatisation' and they envision human rights as possible standard of fairness and legitimacy for taxation. However, they take for granted the power of states to collect taxes. The approach is therefore somewhat 'moral', for the underlying assumption is that paying taxes to states is 'good' for as long as states use that money to fulfil their human rights obligations. There are then 'good' states and 'bad' states, 'good' corporations and 'bad corporations'. What is missing is a more radical analysis of how, historically, the power of taxation has been exercised. The history of taxes is indeed a gloomy one: for taxation has been a key strategy of subjugation and extraction of wealth, of administration of populations and oppression of social groups, of war-making, and so forth. ${ }^{92}$ Hence, human rights should not just offer a formal analysis for the evaluation of fiscal policies: instead, the tension for human rights and taxes ought to offer the ground for a more radical and structural debate on

\footnotetext{
88 Alston \& Reisch (eds.), Tax, Inequality, and Human Rights, p. 19.

89 Avi-Yonah, R.S., 'Globalization, Tax Competition, and the Fiscal Crisis of the Welfare State', Harvard Law Review, 113:7 (2000), 1573-1676 (suggesting developed nations are in dire need of tax revenues).

90 Alston \& Reisch, ibid.

${ }^{91}$ On this point, see, Kaplow, L. and Shavell, S.' Why the Legal System is Less Efficient than the Income Tax in Redistributing Income', The Journal of Legal Studies, 23:2 (1994), 667-681 (challenging the neoliberal assumption of the Chicago School about liberal rights as most effective mean in redistributing income and wealth).

92 The fact that virtually all states today print their own currency is a consequence of the historical difficulty for sovereigns to raise taxes to pay for their wars. To this day, a major share of tax revenues ends up paying for military expenses. For an extensive analysis on money, taxes, and power, see, Desan, C., Making Money: Coin, Currency, and the Coming of Capitalism, Oxford University Press, 2014.
} 
the nature of the state and its functions. ${ }^{93}$

(b) Human rights seem to have relatively little to say about labour. Not only human rights have little to say about labour, but they also interpret labour in fairly liberal terms. In abstract economic models, the free negotiation of wages in exchange for labour should guarantee a relative redistribution of wealth. In the real world, workers have been suffering an erosion of both rights and wages. It is not all about technology replacing workers, however. Several interconnected factors have contributed to the weakened position of workers. In the first place, the current model of globalisation guarantees the free circulation of capital and the relatively frictionless circulation of goods, but it restricts and regulates the mobility of workers. ${ }^{94}$ Controlling the circulation of labour force is functional to depress wages. ${ }^{95}$ Indeed, one 'mystery' of the liberal capitalist system is that while the free circulation of capital and goods increases their respective valuations, in those instances in which labour force is allowed to move, it is more likely to depress wages than to increase them. That is, the circulation of capital and labour generates completely opposite effects. Far from being a 'natural' law of economics, this situation is the product of a legal landscape that allocates gains and losses: a stronger promotion of investors' interests translates into an increasingly weak protection of workers' rights and wages. In the attempt of attracting investment in the form of either capital or business, different jurisdictions compete in offering advantageous tax regimes for investors and companies, shifting taxation burdens from corporate revenues to income from labour. Therefore, workers find themselves to be losers in at least three interconnected ways: stagnant or decreasing wages, higher taxation, but less public services. Indeed, the erosion of tax revenues has made it harder for countries to offer those public services - many of which contribute to the fulfilment of human rights

\footnotetext{
${ }^{93}$ Alston \& Reisch's volume is an impressive collection of high-quality contributions. Assessing and discussing such work is beyond the scope of the present contribution. We limit our analysis to repeat how Alston tends to offer solutions that might not be as radical as they should be, and how the role of the state is being revived by the very human rights that for long espoused a liberal narrative in favor of minimizing the role of states.

${ }_{94}^{4}$ Unger, R., Free Trade Reimagined: The World Division of Labor and the Method of Economics, Princeton University Press, 2007.

${ }^{95}$ Although the measure has broader political objectives, the 'Hukou' system in China is one example of how limiting the free movement of workers is functional to control the cost of labour. See, Wang, H., Guo, F., \& Cheng, Z., 'A Distributional Analysis of Wage Discrimination Against Migrant Workers in China's Urban Labour Market', Urban Studies, 52:13 (2015), 2383-2403; Song, Y., 'Hukou-Based Labour Market Discrimination and Ownership Structure in Urban China', Urban Studies, 53:8 (2016), 1657-1673.
} 
obligations - that alleviate the conditions of the lower class while enabling the middle class (e.g., free health care and free education, effective public transportation, etc.). In the international compartmentalisation of functions, labour falls within the competences of the International Labour Organisation, ${ }^{96}$ which has drafted and ratified about two hundred conventions over time, mostly addressing the conditions of workers on the workplace. But while labour is safer and perhaps greener, ${ }^{97}$ it is becoming more and more challenging to find well-paid positions. Furthermore, a significant share of these standards and regulations are part of trade strategies that aim to preserve the dominance of some actors over others. Human rights are not only rather toothless under these conditions, but as Vidya Kumar has pointed out, the convergence of human rights and labour rights - i.e. the claim that "labour rights are human rights" - depoliticizes important conflicts in international law and thus hides the power disparities that labour law has been so good at revealing. If labour rights have traditionally focused on the relations between the worker and the employer, human rights are focused on the relations between the individual and the state. In a similar vein, if labour law has focused on power disparities, human rights emphasize the imagined equality of all human beings. Hence, recasting labour rights as human rights and thus reimagining the state as the antagonist of the worker and workers and employers as equals may deprive labour rights of their radical edge and shift focus away from concrete power relations of power and inequalities between workers and employers. ${ }^{98}$

(c) Trade is particularly impermeable to human rights concerns. At the same time, trade has enormous distributional consequences. In its current form, trade tends to concentrate gains in the hands of the few, while trade's promise of a better future for all brings the paradoxical outcome of marginalising democracy. ${ }^{99}$ The contemporary 'free trade regime' is an expression of sectorial interests in developed countries, the interests of

\footnotetext{
${ }^{96}$ Maul, D., Human rights, Development, and Decolonization: The International Labour Organization, 1940-70, Palgrave Macmillan, 2012 (noting the increasing tension between competing priorities).

${ }_{97}$ Compa, L., \& Diamond, S., Human Rights, Labor Rights, and International Trade, University of Pennsylvania Press, 1996.

98 Kumar, V., 'Rethinking the Convergence of Human Rights and Labour Rights in International Law: Depoliticisation and Excess,'in Ruth Buchanan and Peer Zumbansen eds, Law in Transition: Human Rights, Development and Transitional Justice (Hart Publishing, 2014).

${ }^{99} \mathrm{Cf}$. Rodrik, D., The Globalization Paradox: Democracy and the Future of the World Economy, W.W. Norton \& Company, 2011, p. xix.
} 
powerful corporations that successfully lobbied their respective government, translated into global rules. ${ }^{100}$ Although the global free trade regime is allegedly crumbling, ${ }^{101}$ the power behind it is stronger than it ever was. Despite significant economic growth, the volumes of international trade are decreasing because most trade occurs within corporations along so-called global value chains. ${ }^{102}$ Built through instruments of corporate law and private law, global value chains can be brutal: they allow corporations to achieve fiscal elusion, social dumping, 103 and avoid a series of other 'externalities' (e.g., compliance to labour and/or environmental regulations) by shifting these 'costs' onto less powerful actors or society at large. A growth in internal trade means that the allocation of resources is less concerned with efficiency and more with preserving the dominant position of the corporation. Indeed, trade is a field in which actors seek dominance. Some suggest that whichever position of dominance comes with costs to defend reputation. ${ }^{104}$ Although corporations might be sensitive to their reputation, they opt for private forms of self-regulation (i.e., Corporate Social Responsibility), ${ }^{105}$ for which human rights issues become part of a broader strategy for competitive advantage and

100 Stiglitz, J., 'Social Justice and Global Trade', Far Eastern Economic Review, $169: 2$ (2006), 18-22; Rodrik, D., Straight Talk on Trade: Ideas for a Sane World Economy, Princeton University Press, 2018.

101 Stiglitz, J., Globalization and Its Discontent Revisited: Anti-Globalisation in the Era of Trump, W.W. Norton \& Company, 2018.

102 Cf. Lund, S., Manyika, J., Woetzel, J., Bughin, J., Krishnan, M., Seong, J. \& Muir, M., Globalization in Transition: The Future of Trade and Value Chains, McKinsey Global Institute, 2019. Global Value Chains have a paradoxical combined effect: on the one hand, they make the world more interdependent; on the other, they also turn it more private and unequal. On the former aspect, see, Cattaneo, O., Gereffi, G., \& Staritz, C., Global Value Chains in a Postcrisis World: A Development Perspective, World Bank, 2010 (interdependence, however, does not mean that weaknesses and risks are evenly distributed along the chain).

103 Aguiar De Medeiros, C., \& Trebat, N., 'Inequality and Income Distribution in Global Value Chains', Journal of Economic Issues, 51:2 (2017), 401-408 (arguing that there are two forms of competition, one at the top of the chain and one at the bottom: the latter is about low wages, the former about the ability to protect intellectual property and capture gains). Stringer, C., \& Michailova, S., 'Why Modern Slavery Thrives in Multinational Corporations' Global Value Chains', Multinational Business Review, 26:3 (2018), 194-206 (with the rise in competition at the lower end of the chains GVCs favour forms of slavery).

104 Wheeler, S., 'Global Production, CSR and Human Rights: The Courts of Public Opinion and the Social Licence to Operate', The International Journal of Human Rights, 19:6 (2015), 757-778 (suggesting 'naming and shaming' could be effective in influencing corporations).

105 Ruggie, J., 'Report of the Special Representative of the Secretary-General on the Issue of Human Rights and Transnational Corporations and Other Business Enterprises', Netherlands Quarterly of Human Rights, 29:2 (2011), 224- 253; also, Ruggie, 'Business and Human Rights: The Evolving International Agenda', The American Journal of International Law, 101:4 (2007), 819-840; Ruggie, 'Protect, Respect and Remedy: A Framework for Business and Human Rights', Innovations: Technology, Governance, Globalization, 3:2 (2008), 189-212; Ruggie, 'Business and Human Rights: Together at Last?', Fletcher Forum of World Affairs, 35 (2011), 117-123; more recently, Ruggie, Just Business: Multinational Corporations and Human Rights, W.W. Norton \& Company, 2013. The UN has issued the so-called Ruggie's Guidelines or Guiding Principles on Business and Human Rights, Office of the High Commissioner for Human Rights, 2001 (HR/PUB/11/04). 
marketing. ${ }^{106}$ At the same time, states have increasingly shied away from leveraging antitrust laws, allowing some corporations to attain a virtually unrestrained global domain. ${ }^{107}$ As the economic and trade competition with China and South East Asian countries has intensified, developed economies have not only reversed their approaches to free trade, at times revamping protectionism, but also carefully balanced the risks of cracking down on dominant or rent positions: while this might favour national consumers, leveraging antitrust could also harm the national interests by weakening national enterprises in times of fierce economic competition. Take the macroscopic example of Amazon: ${ }^{108}$ why would the United States target Amazon with antitrust if the danger is to weaker the overall strategic position of the country against, say, China and its analogous platform of Alibaba? The two global giants are symptomatic of some major transformations occurring in global trade: with the rise of digital platforms and a growing use of proprietary data - more or less intrusively or even abusively 'mined' to feed algorithm, the world is witnessing a new wave of monopolies. ${ }^{109}$ As the role of these digital platforms becomes more and more infrastructural, the helplessness of human rights emerges all the more evidently:110 is it just a matter of privacy and consent? ${ }^{111}$ But isn't consent already an implicit admission of asymmetrical power?

\footnotetext{
106 Scheper, C., "“From Naming and Shaming to Knowing and Showing": Human Rights and the Power of Corporate Practice', The International Journal of Human Rights, 19:6 (2015), 1-20 (arguing that CSR proves the ability of capitalism to absorb and transform fundamental criticism). It has been recently noted how CSR have improved some aspects (e.g., child labour), while undermined others (e.g., unionization of workers), Crinis, V., 'Corporate Social Responsibility, Human Rights and Clothing Workers in Bangladesh and Malaysia', Asian Studies Review, 43:2 (2019), 295-312.

${ }^{107} \mathrm{~A}$ vocal critic of the current inertia in antitrust, Wu, T., 'Taking Innovation Seriously: Antitrust Enforcement if Innovation Mattered Most', Antitrust Law Journal, 78:2 (2012), 313-328. More recently, Wu, T., The Curse of Bigness: Antitrust in the New Gilded Age, Global Reports, 2018.

108 Khan, L.M.,'Amazon's Antitrust Paradox', Yale Law Journal, 126:3 (2017), 710-894.

${ }_{109}$ Zuboff, S., The Age of Surveillance Capitalism: The Fight for a Human Future at the New Frontier of Power, Public Affairs, 2019. Calling for a less enabling role of international lawyers in shaping the new world of 'big data', Johns, F., 'The Deluge', London Review of International Law, 1:1 (2013), 9-34.

110 Joyce, D., 'Privacy in the Digital Era: Human Rights Online?', Melbourne Journal of International Law, 16:1 (2015), 270-285 (noting the relative inability of the UN General Assembly to cope with the complexity of the current transformations).

111 Privacy is the pillar of the European Union's approach to digital platforms and data transfer, Marc Rotenberg, \& David Jacobs. (2013), 'Updating the Law of Information Privacy: The New Framework of the European Union', Harvard Journal of Law \& Public Policy, 36:2 (2013), 605-652. Also, Johns, F. \& Joyce, D., 'Beyond Privacy: Is Prevailing Legal Debate Too Analog for a Digital Age?', Human Rights Defender, 23:3 (2014), 2426. Compliance is however insufficient, Jørgensen, R., \& Desai, T., 'Right to Privacy Meets Online Platforms: Exploring Privacy Complaints against Facebook and Google', Nordic Journal of Human Rights, 35:2 (2017), 106126.
} 
(d) Human rights actors might find it legitimately difficult to understand how to engage with prices. But prices are a crucial part of today's economy and they express the value society attributes to specific goods and services. Some major transformations of the global economy are affecting the way prices are set. For instance, digital platforms are only one side of the increasing 'virtualisation' of trade, the other side being the share of trade in intangibles, which include financial assets. Intangibles require strong protection of property, most notably intellectual property. Intellectual Property Rights (IPRs) have been globalised through the World Trade Organisation (WTO), ${ }^{112}$ as membership to the organisation is made dependant on signing up to the Agreement on Trade Related Aspects of Intellectual Property Rights (TRIPS). Engineered by the Intellectual Property Committee, a coalition of thirteen CEOs from the America largest pharmaceutical, software, and entertainment companies, the TRIPS Agreement established a global regime 'that reaches deep into the domestic regulatory environment of states' under the disputable narrative that they protect inventors and human ingenuity. ${ }^{113}$ However, what IPRs actually do is to securitise investors, while allowing an unprecedented leverage in setting the prices for goods. Indeed, IPRs are an essential tool for promoting a 'subjective' theory of prices, meaning that goods are not sold at a price reflecting their production costs or societal value, but rather aiming at the highest possible price the buyer is able to pay. ${ }^{114}$ This practice dramatically affects, for instance, the cost of medicines, as pharmaceutical companies can freely set prices, often leveraging the fact that states or insurers have an obligation to cover the costs for a given pathology. ${ }^{115}$ IPRs are also effective in capturing value at the expenses of the broader supply chain, for the gains from trade are unequally distributed between labour input and the value of the licensed patent or brand. Ironically, royalties on IPRs can benefit from privileged tax treatment. 116

\footnotetext{
112 Drahos P., The Universality of Intellectual Property Rights: Origins and Development, World Intellectual Property Organization, 1999.

113 Sell, S.K., Private Power, Public Law: The Globalization of Intellectual Property Rights, Cambridge University Press 2003, p. 1. See also, Deere C., The Implementation Game: The TRIPS Agreement and the Global Politics of Intellectual Property Reform in Developing Countries, Oxford University Press, 2009.

114 Mazzucato, M., The Value of Everything: Making and Taking in the Global Economy, Penguin Books, 2018, pp. 207-228 (with particular reference to the pricing of medicines).

115 As Amy Kapczynski puts it, 'a right to medicines imbricated into this regime is plausibly regressive: it places significant strain on healthcare budgets, redistributes upwards, and provides medicines on terms largely dictated by one of the most profitable industries in the world'. Kapczynski, A, 'The Right to Medicines in an Age of Neoliberalism', Humanity Journal, 10:1 (2019), 79-107 at 81.

116 Blair-Stanek, A., 'Intellectual Property Law Solutions to Tax Avoidance.', UCLA Law Review, 62:1 (2015), 273 (arguing that against the inefficacy of tax law, changes ought to be made in intellectual property).
} 
IPRs offer an interesting and effective example of how value is extracted and accumulated: law enables the growing dominance of finance and thus the financialisation of the economy and life more broadly. Finance has become effective in capturing gains at the expenses of other stakeholders. The rise of finance corresponds with an age of globalisation, de-regulation, and inequalities. For instance, the success and prosperity of the financial sector has also corresponded to an explosion of public and private indebtedness. ${ }^{117}$ It is thus ironic how the solution to the problem is at times indicated in a more inclusive system, perhaps making credit scores to access loans 'fairer' (i.e., financial inclusion and inclusive capitalism). ${ }^{118}$ Much of the contemporary financialised economy aims to maximise 'shareholders' value', that is, to more or less artificially increase the price of publicly traded shares. But this means privileging one group of people over others. One main challenge for human rights is then to rebalance the interests of different social groups. This might require reframing the meaning of 'value' in society, ${ }^{119}$ which would also imply redesigning the role of finance.

For better or worse, the human rights movement has so far opted for engaging in somewhat ideological battles in the public sphere, thus neglecting those more technical aspects that have allowed to erect and establish unprecedented forms of private power on a global scale. Distribution and redistribution are decided by:

'[B]y and large, private law regimes such as contract law, corporate law, tort law, property lay, tax law, intellectual property law, commercial arbitration (...) as well as a vast array of private ordering regimes and business practices, including practices to create and exploit commercial advantage as well as industry association standards, corporate codes of conduct and other business-led corporate social responsibility mechanism' ${ }^{120}$

\footnotetext{
117 The International Monetary Fund has recently launched a Global Debt Database, accessible at: www.imf.org/external/datamapper/datasets/GDD (last access, August 7th, 2019). Although the data are still partial, it is possible to observe an increase in both public and private debt over the last decades.

${ }^{118}$ Fleissner, C. 'Inclusive Capitalism Based on Binary Economics and Positive International Human Rights in the Age of Artificial Intelligence', Washington University Global Studies Law Review, 17:1 (2018), 201-244 (supporting the idea of fuller employment to favour income distribution).

119 Lazonick, W., 'Profits Without Prosperity', Harvard Business Review, 92:9 (2014), 46-55. Jacobs, M. \& Mazzucato, M., Rethinking Capitalism: Economics and Policy for Sustainable and Inclusive Growth, WileyBlackwell, 2016.

${ }^{120}$ Danielsen, D., "Situating Human Rights Approaches to Corporate Accountability in the Political Economy of Supply Chain Capitalism" in Brinks, D., Dehm, J. and Engle, K. (eds.), Power to People? Private Efforts to
} 
Therefore, the traditional human rights strategy to hold states accountable for violations of individual rights seem toothless and ill-equipped to deal with the root causes of socioeconomic inequalities in contemporary societies. One could fathom that human rights could still exercise pressure on governments to enact laws and policies to guarantee a certain degree of material equality between citizens. However, there are at least two obstacles. The first is that even in some developed countries, governments have less and less room for manoeuvre. The constraints are said to descend from the political economy of the world, but they are ultimately legal: if a government is pressed in between international investment treaties and human rights obligations, the former will likely prevail. A second obstacle is internal to the human rights movement. As Samuel Moyn has recently argued, to the extent the human rights movement has been mobilised to deal with inequalities, it has settled to easily to raising individuals above the minimum standard of sufficiency. ${ }^{121}$ In other words, it has prioritised sufficiency over equality, thus serving as an unwitting companion to the neoliberal project that has brought forth 'a golden age of the rich'. ${ }^{122}$ In this respect, the human rights movement needs not only better tools to engage into the battlefield of private law, but also a different narrative to disentangle human rights from its complicity with neoliberalism.

\subsection{The 'Complicity' Problem}

The 'age of rights' has corresponded to an explosion of socio-economic inequalities and a 'golden age of the rich'. It is thus fair to question whether human rights might have played a role in that by looking at two dimensions, namely a structural and cultural aspects respectively. In contemporary debates, inequalities are directly associated with the effects of neoliberal policies. While Samuel Moyn sees no immediately interconnection between neoliberalism and human rights, thus characterising human rights as a 'powerless

\footnotetext{
Enforce Human Rights in Supply Chains, forthcoming 2019. It has also been argued that international private law is not necessarily antagonistic to human rights, Watt, H., 'Competition or Confluence? Private International Law and Human Rights in Global Governance', Revue Internationale De Droit Économique, 27:1-2 (2013), 59-78. ${ }^{121}$ Moyn, Not Enough.

122 Ibid., p. 58.
} 
companion' to the neoliberal project, ${ }^{123}$ Jessica Whyte has recently challenged such view, showing an ideological and structural complicity between them. Whyte indeed argues that the hegemonic versions of human rights have been turned into 'the morals of the market',124 that is, into an effective tool for refuting socialist and postcolonial demands for greater economic equality, while upholding 'a neoliberal right to equality [as] a right of everyone to preserve their unequal wealth and power in the face of political demands for redistribution'.125 The present part does not directly engage with such debate, ${ }^{126}$ but it touches on themes that are relevant to it. On the one hand, the human rights language has been used to produce or strengthen some of the legal and economic structures that produce today's radical inequality. On the other, the culture and practices of the human rights movement appear to be broadly liberal, for they embrace the primacy of the private, a certain idea of economic freedom, a preference for technical expertise over politics, and so forth.

(a) A first aspect of complicity concerns the use of human rights for creating or reinforcing the legal and economic structures generating radical socio-economic inequalities. Taken as such, human rights are neither neoliberal nor capitalist, but they might have been instrumentalized into those projects. The inherent emptiness of the rights language has allowed different actors to deploy human rights for interests and purposes contradicting the history and aspirations of the human rights project. For instance, neoliberals have been able to co-opt and redefine human rights to fit them into their own project, recasting trade, market, and capital rights as actual human rights. Since the very start of the neoliberal project in Vienna and Geneva, the fundamental concern was the sanctity of capital mobility'. The aim was to demolish state constraints, that is, to gain access to foreign countries as well as - far more importantly - to have 'the right to sell and leave'.127 In more recent times, Ernst-Ulrich Petersmann replied to the mounting

\footnotetext{
${ }^{123}$ Moyn, S., 'A Powerless Companion: Human Rights in the Age of Neoliberalism', Law \& Contemporary problems, 77:4 (2014), 147-169.

124 Whyte, J., The Morals of the Market: Human Rights and the Rise of Neoliberalism, Verso, 2019, p. 34

125 Whyte, The Moral of the Market, p. 24.

${ }^{126}$ On the intellectual history of neoliberalism, see also, Slobodian, Q., Globalists: The End of Empire and the Birth of Neoliberalism, Harvard University Press, 2018.

127 Slobodian, Q., Globalists: The End of Empire and the Birth of Neoliberalism, Harvard University Press, 2018, p. 145 .
} 
questioning on the legitimacy of the WTO by adopting the very human rights language of protesters, conveniently reinterpreting it as to demand more effective protection of economic freedoms and property rights. ${ }^{128}$ The neoliberal reinterpretation of human rights has not always encountered the sort of strenuous resistance that one might expect from the human rights movement. To the contrary, several human rights and humanitarian NGOs have mobilised human rights language to counter Third World demands for economic redistribution. ${ }^{129}$ Indeed, they rejected the idea for which poverty would be the by-product of the prosperity in the global North, thus placing the responsibility for the plight of the Third World on post-colonial leaders accused of corruption or to oppress their own peoples. This is all the more relevant if one considers the timing: when the New International Economic Order rose to challenge the postcolonial structures of the political economy of the world, human rights ultimately sided with neoliberalism in pushing back. ${ }^{130}$ Considering these historical linkages, it is unsurprising that neoliberals have found human rights a rather useful tool. There are several conceptual connections between human rights and the neoliberal project. Both insist in a relative absoluteness of individual rights against the intrusion and pretenses of governments and states. Human rights offer substantive and procedural guarantees, while also de-politicising particular disputes. Indeed, human rights have somehow espoused the neoliberal logic for which the realm of human emancipation and the only desirable public sphere ought to be found in the market. Moving from this assumption, not only human rights protect private property in fairly strong terms, but they also extend their guarantees to legal persons, that is, companies. ${ }^{131}$ But what does the human rights movement have to say about the increasing privatisation of litigations, that is, the shift from court litigations to private arbitrations or confidential settlements? ${ }^{132} \mathrm{~A}$

128 Ibid., pp. 277-279. See, e.g., Petersmann, E.U., 'The WTO Constitution and Human Rights', Journal of International Economic Law, 3:1 (2000), 19-25; Petersmann, E.U., 'Human Rights and International Economic Law in the $21^{\text {st }}$ Century: The Need to Clarify Their Interrelationship', Journal of International Economic Law, 4:1 (2001), 3-39.

129 Jessica Whyte has convincingly demonstrated how Liberté sans Frontières (LSF), an organisation established by the French leadership of Médecins sans Frontières (MSF), rejected Third World instances and demands using human rights. Whyte, J, 'Powerless Companions or Fellow Travelers? Human Rights and the Neoliberal Assault on Postcolonial Economic Justice ', Radical Philosophy, 2:2 (2018), 13-29.

130 For instance, human rights helped re-signify 'state-led redistribution as a totalitarian threat to liberty and human rights'. Ibid., p. 26

131 For an overview in the European context, Emberland, M., The Human Rights of Companies: Exploring the Structure of ECHR Protection, Oxford University Press, 2006.

132 For instance, there has been a growing reliance on compulsory arbitration clauses in labour contracts. With 
complete mapping of the way human rights intertwine with neoliberalism is beyond the scope of the present paper. But it is worth stressing that far from being 'indivisible, interdependent, and interconnected',133 human rights are often times fragmented and deployed strategically through a selective use and enforcement: some rights are privileged over others; the same rights can be mobilised differently for different projects; and all rights are often interpreted and enforced rather selectively. The end result is that human rights have for some become the 'human rights of capital' ${ }^{134}$

(b) A second aspect pertains to a more sociological sphere, that is, the culture and practices of the human rights movement itself. One traditional critique of human rights is that they belong to a specific social class. For instance, Libby Adler has pointed how the LGBT agenda has been seized to reflect the priorities and interests of a relatively welloff group of activists and donors. Indeed, 'access to marriage was at the forefront of the battle for LGBT advancement for more than a decade, along with anti-discrimination protection, [and] hate crimes legislation'. ${ }^{135}$ At the same time, the many socio-economic problems of LGBTQIA people were entirely disregarded, starting with a rampant percentage of homelessness and a higher exposure to health risks. In other words, the priorities and interests of an 'adequately housed and well-nourished class' obscured and neglected the 'pressing needs in the most marginalised sectors of that community'. ${ }^{136}$ As activism is often dependent on donors, whether private or institutional, a significant part of the work for any human rights organisation has become fund-raising. A fierce competition to attract donations means that 'donors' can directly or indirectly dictate priorities, conditions, and modalities. Ultimately, this carries the risk of turning human rights organizations into companies that embrace the 'shareholders' mentality. Another common critique to human rights is that they are part of a liberal culture, which places courts and legal litigations at the center stage. But access to courts is not as democratic as it should be and its outcomes impact people differently. Those who have the necessary

reference to the United States, see, the dedicated issue on the Berkeley Journal of Employment and Labor Law, 35:12 (2014).

133 Vienna Conference on Human Rights, 1993.

134 Cooper, F., 'Afterword: Social Rights and Human Rights in the Time of Decolonization', Humanity, 3 (2012), 473-492 at 487.

135 Adler, L., Gay Priori: A Queer Critical Legal Studies Approach to Law Reform, Duke University Press, p. 2.

136 Adler, Gay Priori, pp. 2-3. 
financial means can not only access courts more easily, but also hire more specialised lawyers. For example, it has been noted that human rights litigations to gain access to medicines or medications favour the middle class ${ }^{137}$ in at least two significant ways. First, whatever litigation primarily promotes the specific interests of those who brought the case in first place. Sometimes, the situation is even more confusing than that: law firms offer to take on strategic litigations pro bono, while interest groups can finance court cases when they believe it could advance their agenda. Secondly, individual human rights cases can significantly erode the ability of the state to provide public health services because litigations as such as well as successful litigants who are awarded compensations erode the budget, which translate into a cut to services that generally tend to bear more importance to the poor. ${ }^{138}$ Therefore, although human rights litigations are usually presented as pursuing a general public or collective interest, the case of access to medicine proves that this is not always the case. Generally speaking, the human rights movement and its activism are both diverse and disperse. ${ }^{139} \mathrm{~A}$ significant part of the human rights activism intervenes in response to situated crises that do not receive adequate institutional responses, whether locally or internationally. As the human rights movement becomes increasingly specialised and promotes legal cases focusing on narrow points, there is indeed a disconnection between the aim of specific instances and the broader picture. Human rights interventions turn into technical matters, embedding human rights in the culture of expertise. Thus, human rights bend to the inner logic of expertise, thinking like it: they seek specialisation, efficiency, managerialism, and so forth. Therefore, although speaking of root causes of human rights violations have become somewhat fashionable within the human rights movement, there is often little engagement with 'the larger framework within which

\footnotetext{
137 See, e.g., Kapczynski, 'The Right to Medicines in an Age of Neoliberalism'; Ferraz, O.L.M., 'The Right to Health in the Courts of Brazil: Worsening Health Inequities?', Health and Human Rights ,11:2 (2009), 33-45; Ferraz, O.L.M., 'Moving the Debate Forward in Right to Health Litigation', Health and Human Rights, 18:2 (2016), 265-268; Brinks, D.M. \& Gauri, V., “A New Policy Landscape: Legalizing Social and Economic Rights in the Developing World", in Gauri and Brinks (eds.), Courting Social Justice: Judicial Enforcement of Social and Economic Rights in the Developing World, Cambridge University Press, 2008.

138 Reports show that 'litigants frequently obtain expensive and even ineffective medicines that are not recommended by or included in the national formularies that determine what public and private insurers must provide'. Nonetheless, 'courts [can] demand that medicines be provided regardless of their cost, but health budgets are necessarily limited'. Kapczynski, 'The Right to Medicines in an Age of Neoliberalism', p. 78.

139 This is both a point of strength and weakness, as noted by Simmons, B.A., 'The Future of the Human Rights Movement', Ethics \& International Affairs, 28:2 (2014), 183-196.
} 
those conditions are systematically reproduced'. ${ }^{140}$ As human rights activism and battles become more bureaucratic, addressing a given human rights violation may ultimately obfuscate the bigger picture, that is, the conditions of possibility for human rights violations. In turning human rights battles 'technical', even situations like world hunger are made to appear as natural phenomena inscribed into a history of progress instead of the direct outcome of a human-created economic system.

Human rights suffer from two problems, namely helplessness and complicity. Human rights are instrumentalized, whereas the movement seem to share, at least in part, certain mind-sets and practices with neoliberal capitalism. As a consequence, human rights contribute to shape a largely de-politicised world dominated by formal and functional expertise, a world of struggles in which private interests shape the public discourse and institutions to achieve dominance. ${ }^{141}$ Hence, instead of being the voice of the voiceless, human rights risk becoming part of the toolbox of the powerful to assert and advance their projects and interests. As economic and material interests prevail over the effective protection of people, the peril for the human rights movement is to become, more or less unawarely, the guardians of that unequal political economy of the world that it should instead fight. For these reasons, we do not believe that simply doubling down on the existing human rights project with the help of 'familiar strategies' enough. Rather, we need a much more radical approach to human rights.

\section{Reflections}

In the human rights movement, the rise of populist movements has ignited a sense of crisis. The once liberal, democratic, and internationalist Western world is slowly drifting towards more or less marked forms of authoritarianism. In the face of this historical phase, Philip Alston has intervened to defend the merits of the human rights project and double down on it. He has identified a series of problems and advanced a strategy for confronting what he defines as 'unprecedented challenges'. However, the present paper has argued two main

\footnotetext{
140 Marks S., 'Human Rights and Root Causes', Modern Law Review, 74:1 (2011), 57-78 at 71.

141 Kennedy, D., A World of Struggle: How Power, Law, and Expertise Shape Global Political Economy, Princeton University Press, 2016.
} 
things: first, the struggle Alston identifies against populism might turn out misleading; second, the Alston's proposed strategy may prove either ineffective or counter-productive. Indeed, we have aimed at expanding the existing conversation to show how Alston's doubling down on a 'familiar strategy' may fall short from tackling socio-economic inequalities because of some deeper problems that affect the human rights regime and movement.

The human rights project 'has never been a consensus project. It has almost always been a product of struggle'.142 But not all struggles bear the same weight. In Alston's view, the challenge to face is about populism. However, populism is only a tactic that even the human rights movement itself has occasionally made use of. In contrast, the struggle is between human rights and the re-emerging forms of nationalism, which - in all their differences seem equally regressive both psychologically and materially. That is to say, they bring a reflux of xenophobia with an obsession for security, both of which lead to the dismantling of welfare provisions. While the nationalism of the late $19^{\text {th }}$ and early $20^{\text {th }}$ centuries had some vague elements of solidarity, contemporary nationalism is solely identitarian. Nationalist movements leverage the discontent for globalisation and the range of inequalities it brought with it. But what they have to offer is far from their actual rhetoric: most nationalisms have so far privileged those very elites they were meant to battle.

The first great challenge for the human rights movement is therefore that of locating and identifying the actual struggle. Today, there are ghostly forms of dominance that mainstream versions of human rights are unequipped to challenge. A traditional logic of 'naming and shaming' can only superficially - and thus insufficiently - scratch a system of dominance largely built upon and throughout forms of private law. ${ }^{143}$ Engaging with private law also means that power is hardly visible and centralised. Geneva and New York, for how relevant, cannot become the sole focus of action. Hence, the movement ought to

\footnotetext{
142 Alston, 'The Populist Challenge', p. 3.

143 See, e.g., Watt, H., 'Competition or Confluence? Private International Law and Human Rights in Global Governance', Revue Internationale De Droit Économique, 27:1-2 (2003), 59-78; Watt, H., “Theorizing Private International Law", in Orford, A. and Hoffman, F. (eds.), The Oxford Handbook of the Theory of International Law, Oxford University Press, 2016, pp. 862-882; Watt, H., 'When Societal Constitutionalism Encounters Private International Law: Of Pluralism, Distribution, and "Chronotopes"', Journal of Law and Society, 45:1 (2018), 185203.
} 
reach 'the ends of the network, where people are using human rights promiscuously as they build power locally'. ${ }^{144}$ In other words, the effects of an increasingly sophisticated and private dominance are felt first and foremost in local and apparently marginal instances.

Human rights have already won many battles. It is thus understandable how one could imagine confronting today's challenges of populism and inequalities with 'the recipe that we have developed for civil and political rights promotion', that is, recognition, institutionalisation, and accountability - just applied to economic and social rights. However, the human rights movement has first to sort out its complicity with that very system it aims to transform. There is need for a human rights movement that sees and reveals rather than denies connections between rights and markets'. ${ }^{145}$ Human rights have to come to terms with their recent past, their relation to markets, as well as their own power. That is, the embeddedness of human rights within the political economy of the world and,146 as Jessica Whyte has noted, the complicity of human rights with neoliberalism. Without doing so, the danger is to repeat mistakes and be ineffective at best or damaging at worst. For instance, there is the relative risk to create a new group of international experts that will ultimately establish de-politicised bureaucratic processes and vocabularies, exploiting struggles rather than fighting them. ${ }^{147}$ The future of human rights and their movement cannot be one of further de-politicisation.

The struggle against nationalist movements is ultimately one of narrative and imaginary. In this battle, human rights must be able to win back the streets, politics and media and be able to work with different actors from environmentalists to labour unions which are more equipped to deal with some of the issues that have contributed to the current situation. ${ }^{148}$ Although Alston laments that academic critiques of human rights serve little purpose other than infusing a sense of hopelessness into students, we believe it is through critique that

\footnotetext{
144 Kapczynski, A., 'What Comes after Not Enough?', Law and Political Economy Blog, available at https://lpeblog.org/2018/06/11/what-comes-after-not-enough/ (last access, August 5th, 2019)

145 Kapczynski, 'What Comes after Not Enough?'.

146 Manfredi, Z., 'Recent Histories and Uncertain Futures', Qui Parle, 22:1, 2013, 3-32, p. 5: 'human rights are not only inefficacious tools but also collaborators in a pernicious politics of inequality and domination'.

147 Koskenniemi, 'Human Rights Mainstreaming as a Strategy for Institutional Power'.

148 Goldston, J.A., 'A Wake-up Call for Human Rights', Project Syndicate, available at https://www.projectsyndicate.org/commentary/human-rights-groups-criticism-populism-by-james-a-goldston-2019-08 access on August 21st, 2019).
} 
new narratives can emerge to regenerate the human rights enterprise. Part of the task is historiographical,149 for the neoliberal hijacking of human rights has foreclosed alternative and potentially more powerful traditions that should be rediscovered and revived. ${ }^{150}$ Historically, the forgotten foundational principle of not solely human rights, but also of nations, is less that of formal equality than that of solidarity. Indeed, the debate about and around formal versus absolute equality is inevitably inconclusive: full material equality is impossible (for there can never be a condition in which everyone is equal to everybody else in everything) while formal equality is insufficient. Just like freedom and equality cannot be taken apart, 151 so do equality and solidarity. For formal equality to be effective, it has to come with solidarity ties based not a mere sufficiency but on mutual insurance and redistribution. The French Revolutionaries proclaimed 'freedom, equality, and brotherhood', the latter being a demand for material solidarity among the members of the same community. At the same time, the idea of nation, as it emerged throughout the 19th and $20^{\text {th }}$ centuries, was an imagined community that entailed a fundamental principle of solidarity among its members, a solidarity that entailed a public form of mutual insurance.

Contemporary forms of nationalism replace material solidarity with empty narratives about 'crippled' identities, that is, national identities that can only stand in opposition to some 'enemy' ${ }^{152}$ they instrumentalize migration to antagonize the 'other' and create a fictitious sense of community under attack, to denigrate global solidarity while also cutting back on those material forms of national solidarity known as welfare, to marginalise the role of the state in providing for its less fortunate members at the advantage of private forms of philanthropy. Therefore, one way the human rights movement can take over the new wave of nationalism is to offer more credible and tangible answers: against the erosion of social

\footnotetext{
149 There has already been a historiographical turn in the field of human rights. See, Moyn, S., The Last Utopia: Human Rights in History, The Belknap Press of Harvard University Press, 2010; Moyn, S., Human Rights and the Uses of History, Verso, 2014; Alston, P., 'Does the Past Matter? On the Origins of Human Rights', Harvard Law Review, 126, 2012-13, 2043-2081; Slotte, P. and Halme-Tuomisaari, M. (eds.), Revisiting the Origins of Human Rights, Cambridge University Press, 2015.

${ }^{150}$ For example, see, Marks, S., A False Tree of Liberty: Human Rights in Radical Thought, Oxford University Press 2019.

${ }^{151}$ Balibar, E., 'The Proposition of Equaliberty', in Equaliberty, Duke University Press, 2014, pp. 67-98.

152 The binomial 'friend-and-enemy' revives the unhappy characterization of the political given in Schmitt, C., The Concept of the Political, Chicago University Press, 2007, p. 26.
} 
bonds and state welfare, human rights can revive the forgotten principle of collective solidarity both within and beyond national borders. 


\section{HUMAN RIGHTS, POPULISM, AND THE POLITICAL ECONOMY OF THE WORLD}

\section{Luca Bonadiman* and Ukri Soirilat}

The commonly shared sentiment that human rights have reached a crisis in the form of a populist backlash has produced a vibrant discussion on the causes of and solutions to the crisis. This article seeks to contribute to that discussion by engaging with Philip Alston's important and influential essay on the topic, and in particular with his project of tackling material inequality. In so doing, the article makes two main points. First, it argues that the populism is most of all a form or a tactic, and the true antagonistic opponent of human rights might be the nationalist substance of populism. Secondly, the article agrees with Alston that a key reason for the populist backlash is material inequality, but challenges his view that the solution to the problem is to double down on 'familiar strategies' by simply providing social and economic rights a more prominent position within the human rights project. By contrast, the article suggests that a radical renewal of the human rights movement is called for - one accompanied by a more elaborate diagnosis of how human rights have been linked to inequalities and how they can engage with the structures and actors producing those inequalities. Trying to understand why human rights have lost ground to nationalism, the article suggests that a first step towards such more radical and dynamic human rights might be to unearth the now largely forgotten concept of solidarity, which once played a key part in the motto 'liberty, equality, fraternity'.

Keywords: human rights, inequality, Philip Alston, populism, social and economic rights, solidarity

\section{Introduction}

A crisis of project or a discipline is always also an opportunity for development, either through refocusing or invention. ${ }^{1}$ Such is the case also with the current situation in which many commentators see the global liberal order of human rights being challenged by a socalled 'populist backlash'. Indeed, the populist challenge to human rights has produced a vibrant discussion regarding the future of human rights and the accomplishments and shortcomings of what this article refers to as the 'human rights movement' 2 - a contested

\footnotetext{
* Non-Residential Fellow at the Institute for Global Law and Policy at Harvard Law School. † Lecturer in International Law and Human Rights at the University of Helsinki, Faculty of Law. The authors wish to thank the editors and reviewers at the Nordic Journal of Human Rights for their constructive and insightful comments. Many thanks also to Prof. David Kennedy, Prof., Lucie White, and Michael Picard for their feedback on prior versions of the draft.

1 The notion of 'crisis' would deserve a much longer discussion, as it can acquire significantly diverse meanings. For a brilliant conceptual analysis, see: Koselleck, R., 'Crisis', Journal of the History of Ideas, 67:2 (2006), 357-400.

2 On the difficulty of using the term, see Alston, P., 'Reply to Dudai and Nagaraj', Journal of Human Rights Practice, 9 (2017), 25-28, pp. 25-26. On the history of the human rights movement, see Neier, A. The International Human Rights Movement: A History, Princeton University Press, 2012. Tracing the history further into the past, see Iriye, A., Goedde, P., \& Hitchcock, W., The Human Rights Revolution: An International History, Oxford University Press, 2012.
} 
term which is used here to refer in particular to a wide range of mainstream, global human rights actors, including the best known (often Western) human NGOs, experts, scholars, and institutions; but mostly excluding more localized and grassroot forms of human rights activism.

One of the most important aspects of this discussion has been its increasing focus on issue of material inequalities, ${ }^{3}$ which is commonly seen as one of the root causes of the populist backlash. As critics have asked, is it not puzzling that the 'age of rights' 4 has coincided with a sharp increase in inequalities both between and within countries? ${ }^{5}$ How has the age of rights' become an 'age of inequalities'? ${ }^{6}$ Is this just a coincidence or do human rights play a part in the political economy of the world? ${ }^{7}$

This article seeks to contribute to the discussion on the populist backlash, and in particular to the issue of human rights and inequality, by engaging with Philip Alston's insightful and influential essay on the topic. ${ }^{8}$ In seeking to galvanize human rights proponents against looming loss of faith, Alston touches on several pertinent issues regarding the crisis of human rights, one of which is of particular interest for the present article. This is his suggestion of tackling the questions of inequalities with increased focus on social and economic rights while doubling down on the familiar human rights strategies of recognition, institutions and accountability. ${ }^{9}$ Although we agree with Alston that increased focus on social and economic rights is needed, we dispute that doubling down on the existing project is the best path forward. By contrast, in arguing that the 'crisis' of human

\footnotetext{
${ }^{3}$ For a comprehensive debate about human rights and inequalities, see the recent issue of Humanity, in particular, Brinks, D., Dehm, J., and Engle, K., 'Introduction: Human Rights and Economic Inequality', Humanity, 10:3 (2019), 363-375.

${ }^{4}$ The expression 'age of rights' has been notably coined by Henkin, L., The Age of Rights, Columbia University Press, 1990; for a similar account from the field of political theory, Bobbio, N., The Age of Rights, Polity Press, 1996 (also offering a periodization of human rights).

${ }^{5}$ For a recent, influential analysis on the interconnection, see: Moyn, S., Not Enough: Human Rights in an Unequal World, The Belknap Press of Harvard University Press, 2018.

${ }^{6}$ See, Milanović, B., Global Inequality: A New Approach for the Age of Globalization, The Belknap Press of Harvard University Press, 2016. For a more extensive and equally notorious analysis over a much longer timeframe, Piketty, T., Capital in the Twenty-First Century, Harvard University Press, 2014 (making the point that a major cause of inequalities is the differential between the return rate on capital and on labour).

7 See, Kinley, D., Civilizing Globalization: Human Rights and the Global Economy, Cambridge University Press, 2009; Whyte, J., The Morals of the Market: Human Rights and the Rise of Neoliberalism, Verso, 2019.

8 Alston, P., 'The Populist Challenge to Human Rights', Journal of Human Rights Practice, 9 (2017), 1-15.

${ }^{9}$ Ibid., p. 9.
} 
rights might be less about populism than its entanglement or complicity with an unequal distribution of opportunities and resources around the world, we suggest that defending human rights might require a deeper and more granular understanding of how and to what extent human rights have been 'part of the problem'. ${ }^{10}$

The article is comprised of four further sections. Section 2 briefly outlines Alston's main arguments and the responses it has attracted. The next two sections engage with two of Alston's arguments in more detail. Section 3 contends that today's main challenge for the human rights and the movement supporting them is less about pushing back on populism and the nationalist agendas they support than to focus on structural and distributional problems. Section 4 takes on Alston's aforementioned plan of doubling down on the existing human rights project, albeit with added focus on social and economic rights, by pointing out two key challenges in this regard: the incapacity of current conceptions of human rights to address some root causes of inequality, and their possible complicity to other such causes. Section Five argues that every 'crisis' is also an opportunity. In so doing, it suggests that a path forward for the human rights movement could be provided by unearthing the forgotten concept of solidarity and thus drawing from a now marginalized but more radical tradition of human rights thinking.

\section{Doubling Down on Human Rights}

In a recent article, Philip Alston confronts the current backlash on human rights, sketching out a possible path forward. ${ }^{11}$ Alston's contribution is important not solely because of the substantive insights he provides, but also because of his role of leadership within the human rights movement and regime. For Alston has an incredible track record: he is one of the most - if not the most - renown international human rights scholars, a prominent supporter and maker of the human rights regime, who has indeed held several prestigious appointments at the United Nations (UN), including two mandates as UN Special Rapporteur. ${ }^{12}$ Writing

\footnotetext{
10 The choice of words is inspired by Kennedy, D., 'International Human Rights Movement: Part of the Problem?', Harvard Human Rights Journal, 15 (2002), 101-125.

11 Alston, 'The Populist Challenge', pp. 4-7. See also, Alston, P., 'Human Rights Under Siege', International Journal on Human Rights, 14:25 (2017), 267-272.

12 Philip Alston was Special Rapporteur on Extrajudicial, Summary or Arbitrary Executions between 20042010; and he has held the office of UN Special Rapporteur on Extreme Poverty and Human Rights since 2014.
} 
from the perspective of both an academic and as Special Rapporteur, his views bear considerable weight within the human rights movement and regime. Therefore, Alston's take on the situation is paradigmatic for a much broader range of scholars, professionals, and activists. We thus believe that his view demands a closer scrutiny.

Alston identifies five key challenges in the era of populist backlash, which entail that human rights proponents need to rethink many of their assumptions, re-evaluate their strategies, and broaden their outreach' - albeit 'without giving up on the basic principles' of the movement. ${ }^{13}$ The first challenge is the populist threat to democracy and, in particular, the growing willingness to sacrifice individual and collective freedoms at the altar of security. The second challenge is about the shrinking space for civil society, which is not only diminishing rapidly, but has already been entirely closed in many parts of the world. The third challenge is to find ways to address the issues of inequality and exclusion more effectively. The fourth challenge concerns the undermining of the international rule of law, especially with regard to the use of force vis-a-vis the marginalisation of international humanitarian law. Finally, the fifth challenge regards the fragility of international institutions, many of which - included but not limited to the International Criminal Court, the Human Rights Committee, the European Court of Human Rights, and the InterAmerican Court of Human Rights - have come under immense pressure due to budget cuts, the withdrawing of some members, or the unresponsiveness of others when it comes to planned 'reforms'.14

In response to such challenges, Alston suggests five strategies for addressing the perceived crisis. First, the human rights movement ought to develop better synergies between international and local human rights activism. Secondly, the human rights movement should include economic and social rights as important and authentic part of the overall human rights agenda. A third point is to broaden the outreach to identify new actors for cooperation, including corporations. Fourth, Alston advocates for new and more persuasive communication strategies to more effectively engage both states and general public: instead of limiting its role to denouncing violations, the human rights movement could put forth

\footnotetext{
${ }^{13}$ Alston, 'The Populist Challenge', p. 2.

${ }^{14}$ Ibid. pp. 4-8.
} 
less absolute arguments in order to structure a more prolific dialogue. Finally, Alston questions the benefits and scope of some critical scholarship, calling for a greater sense of responsibility on the part of human rights scholars. ${ }^{15}$

Alston's article has sparked a discussion which the present article also seeks to contribute to. For example, Vijay Nagaraj reflects on Alston's arguments through his experience with human rights protection in Sri Lanka. Nagaraj questions whether human rights have become too much of a language of 'law and other mechanisms of top-down authorization'; whether such embracement of procedures has brought advocates to lose their ability to speak of the idea of human rights 'as deriving from a deeper place, from a sense of relational ethics, love, compassion and solidarity'. ${ }^{16}$ Notably, Nagaraj acknowledges that human rights advocates in Sri Lanka have more or less ignored issues of economic harms and distributive injustices, many prominent activists believing that the human rights movement should focus on civil and political rights instead. This, Nagaraj seems to hint, could be due to the fact that the financial support for most human rights work in the country comes 'from the United States Agency for International Development (USAID) that is channelled through large for-profit contractors like Tetra Tech, Chemonics and others' for whom 'human rights is really just one more business'. ${ }^{17}$

In another response, Ron Dudai invites scholars to pay greater attention to the possible root causes of the populist backlash. For example, too little consideration is given to internal disillusionment, even though many of those who are 'ideologically aligned' with human rights values have grown increasingly frustrated with the inability of human rights institutions to 'deliver the goods'. ${ }^{18}$ At the same time, the constant attempt to fit human rights into other frameworks, such as development or climate change, has also caused their inflation and dilution. The lack of coherence might have made it easier for conservative and populist movements to hijack human rights language and causes. Not all problems are

\footnotetext{
${ }^{15}$ Ibid. pp. 8-13.

${ }^{16}$ Nagaraj, V.K., 'Human Rights and Populism: Some More Questions in Response to Philip Alston', Journal of Human Rights Practice, 9 (2017), 22-24. p.24

17 Ibid. 23.

${ }^{18}$ Dudai, R., 'Human Rights in the Populist Era: Mourn then (Re)Organize', Journal of Human Rights Practice, 9 (2017), 16-21, p.17.
} 
'cultural' though. For instance, Dudai notes how new technologies have allowed almost anyone to document or claim possible human rights abuses, thus eroding the traditional role of human rights organizations. ${ }^{19}$ To confront these challenges, Dudai suggests that human rights organizations should rethinking the meaning of human rights activism tout court. In so doing, Dudai notes the difference between diplomatic forums such as Geneva and local activism, and argues that there is need to reconnect human rights with grassroots social movement and struggles so that human rights are not deployed in abstract discussions but to campaign against very concrete injustices. The rethink of the human rights platform and strategy ought to be particularly radical when it comes to economic and social rights; for Dudai, the time may have come to take a stronger stance against 'free markets' in favour of more effective forms of redistribution from the rich to the poor. ${ }^{20}$

Nagaraj and Dudai expose the two areas in which we believe Alston's intervention is perhaps incomplete. First, we agree with Dudai on the need for 'a more elaborate diagnosis' of the reasons of the 'current crisis' of human rights, ${ }^{21}$ for the polemical contention with populism might prove misleading. ${ }^{22}$ Secondly, we share with Nagaraj the sense that the bias and limits of the human rights regime and activism when it comes to economic and social rights runs deep, making Alston's envisioned solution potentially ineffective or at least insufficient.

Alston acknowledges that populism has been driven, at least in part, by legitimate sentiments for worsening economic conditions and rising inequality. He laments how mainstream human rights advocacy has addressed 'economic and social rights issues in a tokenistic manner at best, and the issue of inequality almost not at all', 23 causing a loss of faith in human rights. Indeed, many now feel 'they have no stake in the human rights

\footnotetext{
${ }_{19} \mathrm{Ibid}$. 17-18. On the role of technology in human rights documentation, see also Gregory, S., 'Cameras Everywhere Revisited: How Digital Technologies and Social Media Aid and Inhibit Human Rights Documentation and Advocacy', Journal of Human Rights Practice, 11 (2019), 373-392.

${ }^{20}$ Dudai, 'Human Rights in the Populist Era', p. 19.

${ }^{21}$ Ibid. p. 17.

${ }^{22}$ Also addressed by Koskenniemi, M., 'Alston Rocking the Human Rights Boat: Reflections by a Fellow Passenger' (forthcoming).

${ }^{23}$ Alston, 'The Populist Challenge', p. 6. See also UN Human Rights Council (2015), Report of the Special Rapporteur on extreme poverty and human rights, Philip Alston. A/HRC/29/31.
} 
enterprise' ${ }^{24}$ To counter the populist backlash, human rights actors must therefore give economic and social rights a more central role in the human rights agenda so as to address the concerns 'of those who feel badly done by as a result of what we loosely call globalization-driven economic change' ${ }^{\prime 25}$. As Alston points out, this means that 'human rights proponents need to start looking at budgets, at tax policy, and at fiscal policies in general' - that is to say, all those issues that they have long tried to avoid. ${ }^{26}$

However, Alston's formula for harnessing human rights to tackle inequalities is less radical than it might sound. What is not needed, he warns, 'is to move the focus to the blight of poverty $(. .$.$) or to the need for more resources for development'. For Alston fears that when$ 'the rights are conflated or confused with development, or poverty alleviation', the campaign starts to seem 'huge and overwhelming', thus further alienating states afraid of burdening costs. ${ }^{27}$

Instead, Alston suggests that the solution is to follow an existing and familiar path, that is, 'to follow the recipe that we have developed for civil and political rights promotion' in order to advance social and economic rights as well. ${ }^{28}$ Such 'recipe' is about recognition, institutionalisation, and accountability:

'We need to (...) start with legislative and other forms of recognition of a right (...). Next we need to build up specialized institutions which are going to promote the right in ways that are meaningful in that society. And finally, we need to build up accountability mechanisms'.29

As Alston puts it, 'in terms of these essential elements of recognition, institutionalisation, and accountability, economic and social rights are no different' from civil and political rights' ${ }^{30}$ Hence, it appears to us that Alston is advocating for doubling down on what has been the key program and strategy of the human rights movement since the 1970s.

\footnotetext{
${ }^{24}$ Alston, 'The Populist Challenge', p. 6

25 Ibid.

${ }^{26}$ Ibid. p. 10.

27 Alston, 'The Populist Challenge', p. 9

28 Ibid.

29 Ibid.

30 Ibid.
} 
Alston is not alone in this 'doubling down' approach. In other recent contributions to the Journal of Human Rights and Practice, different scholars ultimately echo the very same strategy of doubling down. For example, Paul Gready defends the importance of human rights work even when success is uncertain and responses hostile because it is the right thing to do and because moral acts 'leave a trace, sow a seed' ${ }^{31}$ The challenge, as he sees it, lies mainly in communication: the human rights movement ought to spend more time and energy on being persuasive, on learning how to frame arguments, how to embed facts in compelling narratives about the future of society, and on rethinking solidarities without and within. ${ }^{32}$

In a different article, Mark Heywood also suggests that the way forward in promoting economic and social rights is to double down on the existing human rights platform. Heywood starts from a more drastic position than Alston, writing that the realization of socioeconomic rights under neoliberal forms of capitalist economy is perhaps impossible. He thus invites human rights scholars and advocates to show greater courage and willingness to address the question of who has control, who wields power. ${ }^{33}$ Furthermore, Heywood concedes to critics that human rights may have at times 'looked like a handmaiden to neoliberalism', for the forms of power and interest at play in capitalism found they have 'a self-interest in advancing human rights frameworks' ${ }^{34}$

While Heywood's analysis is perhaps more radical than Alston's, his solutions are nonetheless remarkably similar. For Heywood provides a powerful defence of human rights, pointing out that they have 'achieved significant pro-poor reform in the last two decades', and that surrendering the framework would 'leave us much weaker in our fight for equality.' ${ }^{35}$ Indeed, if the human rights covenants have produced disappointing results, this is so, according to Heywood, primarily because the United Nations Treaty Bodies they

\footnotetext{
${ }^{31}$ Gready, P., 'Reflections on a Human Rights Decade, Near and Far', Journal of Human Rights Practice, 11 (2019), 422-437, p. 423. Gready draws from Shulman, D.. 'On the Goodness of Despair', Journal of Human Rights Practice 6:3, (2014), 503-510.

${ }^{32}$ Gready. 'Reflections on a Human Rights Decade', 431-435.

${ }^{33}$ Heywood, M., 'South Africa's Journey from Socialism to Human Rights: The True Confessions of an Errant Socialist', Journal of Human Rights Practice, 11 (2019), 305-323, p. 318

${ }^{34}$ Ibid. 317.

35 Ibid.
} 
produced 'have not yet been effectively utilized by civil society to demand their enforcement as global standards'.36 Therefore, Heywood believes in doubling down on the existing human rights project and institutions, too.

The general consensus for doubling down on the existing human rights platform is married with a twofold appeal: human rights activism ought to find better ways of communicating and also be more pragmatic. In practice, this approach translates into reviving the legal potential of the United Nations' International Convention on Economic, Social, and Cultural Rights (ICESCR). ${ }^{37}$ Indeed, both Alston's and Heywood's arguments point to Olivier de Schutter's work against regressive socio-economic measures. Indeed, de Schutter notes that most states have already ratified the ICESCR, but argues that they enjoy excessive discretion in implementing it. The problem, as he sees it, is one of accountability and therefore justiciability of economic and social rights. To counter such problem, de Schutter claims that both regressive policies and non-implementation amount to violations of the Convention. ${ }^{38}$ As economic and social rights are already recognised and enshrined within a legally binding convention, the human rights movement should focus on greater institutionalisation and accountability, thus becoming more vigilant and capable of evaluating economic and fiscal policies to ensure the state compliance to its core obligations.

There is great merit to de Schutter's approach. There are some relative risks, too. For example, expanding the 'recognition, institutionalisation, and accountability' strategy to economic and social rights in the way Alston, Heywood, and de Schutter envision is likely to also double down on that culture of expertise that has come under scrutiny and has been the target of populist attacks. For holding states accountable on the economic and social obligations can only translate in greater demand for new types of international expertise. The struggle thus becomes one between the alleged moral primacy of human rights and technical neutrality of international bureaucracies versus the 'politics' of populist movements. The implied danger is therefore that of fuelling rather than defusing populism.

\footnotetext{
36 Ibid. 318.

37 See also, Uprimny Yepes, R. and Chaparro Hernandez, S., 'Inequality, Human Rights, and Social Rights: Tensions and Complementarities', Humanity, 10:3 (2019), 376-394.

38 De Schutter, O., The Rights-Based Welfare State: Public Budgets and Economic and Social Rights, Friedrich Ebert Stiftung, 2018, p. 3, 9.
} 
This perhaps superficial example about expertise suggests that Alston's grievance against 'destructive and irresponsible' critical scholarship is perhaps short-sighted. ${ }^{39}$ As Martti Koskenniemi put it, 'taking a break from criticism of human rights (...) is not likely to strengthen them' either, for the present problems of the movement are less a consequence of critical scholarship and more 'by the intellectual autism of human rights culture'.

The present article indeed responds to the calls of both Dudai and Koskenniemi, for 'more awareness is needed about what the "backlash" stands for and what might be needed in response to it'. ${ }^{40} \mathrm{~A}$ more attentive analysis of the current threat means identifying the actual problems and challenges so to provide more effective strategies. We want to question whether, if 'the challenges ... are fundamentally different', the most effective strategy is to really double down on the existing recipe. For instance, such view avoids confronting uncomfortable demands on how human rights may have contributed to the existing discontent. Doubling down on the human rights program without first understanding its entanglement with the world could prove both ideological and risky, as it might turn into a doubling down on errors and regrettable mistakes. Therefore, our intent is not that of contesting Alston, but rather that of broadening the scope and terms of the current debate about and around the threats of populism and the ability of human rights to engage with issues of inequalities.

\section{Human Rights and Populism}

Although the main focus of this article is on Alston's call to double down on the existing human rights project to address material inequality, we agree with Dudai that addressing that problem requires some more conceptual clarity regarding the so-called crisis of human rights, for such clarity may help assess the steps that are needed to reorient the human rights movement. In seeking to provide more elaborate conceptual lenses through which to view the 'crisis', we wish to question whether presenting human rights and populism as antagonistic opposites to each other is the best possible path forward.

\footnotetext{
${ }^{39}$ Dudai, “Human Rights in the Populist Era', pp.19-20. See also, Sharp D.N., 'Through a Glass, Darkly: Three Important Conversations for Human Rights Professionals', Journal of Human Rights Practice, 11 (2019), 296-304, pp. 299-300.

${ }^{40}$ Koskenniemi, 'Alston Rocking the Human Rights Boat'.
} 
As Alston writes, echoing many similar voices, 'the populist agenda that has made such dramatic inroads recently is (...) explicitly antagonistic to all or much of the human rights agenda'. ${ }^{41}$ But although Alston has good reasons for this statement, this section argues that viewing populism as the antagonist of human rights might ultimately prove misleading. 42 In so doing, the section makes two points: first, populism ought to be understood not as an agenda but as a tactic or a tool; and secondly, the actual challenge to human rights is thus not populism as such, but how nationalist uses of populist tactics are eroding the democratic fabric of liberal states on the two shores of the North Atlantic and beyond.

As we argue, shifting the focus on nationalism might help reorient the human rights movement. For much like populism, nationalism is also far from a monolithic entity. At least in Western states, nationalist populism has taken two very damaging forms. Firstly, populist rhetoric has been used to exclude various 'others' from asylum seekers to minorities. Secondly, and importantly for this article, it has also been used to justify drastic economic projects, such as the kinds of tax 'reforms', which have turned out to be mostly tax cuts that benefit large corporations and shareholders. ${ }^{43}$ However, in addition to these destructive forms, there is also a positive element to nationalism - one which perhaps has appealed to the public but which has been entirely ignored in the contemporary populist practices. This element is solidarity, which is the forgotten term from the revolutionary triad 'freedom, equality, solidarity'. As we argue, returning solidarity to its place of honour may help reprogram the human rights movement and gain back some ground that it has lost to nationalist populism.

\section{3..1 On Populism...}

${ }^{41}$ Ibid. p. 1.

42 This antagonism echoes Oakeshott, M., The Politics of Faith and the Politics of Scepticism, Yale University Press, 1996 (arguing that democracy is a dialectic between two forces, faith and scepticism). Populist movements would embody the politics of faith, whereas human rights and their resistance would embrace the politics of scepticism.

43 See, for the United States, the Tax Cut and Jobs Act ('An Act to provide for reconciliation pursuant to titles II and V of the concurrent resolution on the budget for fiscal year 2018'), Public Law No. 115-97, 2017. Read further, August, J.D.,' Tax Cuts and Jobs Act of 2017 Introduces Major Reforms to the International Taxation of U.S. Corporations', The Practical Tax Lawyer, 32:2 (2018), 43-54. 
One has to be careful when discussing populism - especially in the international context for there are so many modes of it, from conservative to progressive and right-wing to leftwing versions. ${ }^{44}$ Nevertheless, there are some elements that at least most versions have in common. Whether one intends it as ideology, discourse, or strategy, populism is about seizing power - most notably, state power. Populism does not have any substantive government program of its own because it is mostly a tactic to occupy the state via the formally regular course of democratic processes. ${ }^{45}$ Indeed, populist leaders run in the general elections, often through the very party system they ultimately undermine. They seduce voters with bombastic rhetoric and the lure of untenable promises, the realisation of which is often made dependant on the preliminary defeat of some real or imaginary 'enemy', thus exacerbating divisions and conflicts in society. Once in government, many populist movements display remarkably authoritarian traits: in face of poor performances in delivering on any such promise, the frequent populist response is to blame some internal or external 'enemy'. ${ }^{46}$ This could be a foreign government allegedly interfering with internal affairs, some minority conspiring against the people and the state, or even the so-called 'deep state' 47 that supposedly hinders the otherwise effective action of the government with rules and procedures, thus offering additional momentum to push back on checks and balances. The rhetorical use of the more or less invisible enemies further allows populist leaders to assert a monopoly in speaking for 'the people'. ${ }^{48}$ Hence, populist leaders and movements can steer negative sentiments of a purported majority to seek an even stronger mandate through new elections, ultimately transforming the political life of a country into an endless electoral campaign. ${ }^{49}$

\footnotetext{
${ }^{44}$ For an overview of different theories and interpretations, Anselmi, M., Populism: An Introduction, Taylor and Francis, 2017.

45 Populism has been also intended as 'political style' or 'performance', see, Moffitt, B., The Global Rise of Populism: Performance, Political Style, and Representation, Stanford University Press, 2016 (pointing to the role of technology as contributing to the success of populism. New digital platforms offer political leaders or representatives a way to communicate 'directly' with their supporters).

${ }^{46}$ This strategy is carefully described in Jünger, E., Der Waldgang, Klett-Cotta, 1986 (detailing the Nazi strategy of growing consensus while justifying failures by producing internal and external enemies).

47 E.g., Santos, R., The Deep State, Greenhaven Publishing, 2018 (focusing on the military industry and apparatus). The deep state is largely regarded as one of the many 'conspiracy theories' of contemporary politics. It is a way to refer to unelected bureaucrats that use their authority and prerogatives to trump political decision making in order to advance personal agendas.

48 Müller, J.-W., What Is Populism?, University of Pennsylvania Press, 2016 (arguing that contemporary populism represents a cultural reaction to pluralism).

${ }^{49}$ A phenomenon that has become intrinsic to American democracy (see, Lexington, 'The Endless Campaign', The Economist, August 27th 2001), but has intensified and spread to other Western democracies.
} 
Taken this way, populism is a 'malady' of liberal democracies - a 'malady' primarily affecting the way some political groups organise and strategize to seize and retain state power. ${ }^{50}$ Therefore, this 'disease' affects multi-party democracies when existing political parties fail to renovate and grow distance from their voters, especially in times of economic crisis. Surfing the discontent and appealing on the perceived self-referentiality of political parties and state bureaucrats, populist leaders often win support from voters presenting themselves as statesmen ready to 'drain the swamp'. ${ }^{51}$ Indeed, another common feature of populist movements is to assert their moral primacy over other, allegedly corrupt, groups. However, once installed into office, populist leaders or movements display a preference for loyalty over competence (i.e., 'clientelism'), 52 the inclination towards forms of protectionism (to acquire and reward clients), an idiosyncratic understanding of security, and so forth, thus exacerbating those negative features they were meant to fight. Largely centred on the charismatic figure of a leader, populist movements tend to unsettle the traditional division of powers, often marginalising the legislative branch at the advantage of the executive.

What these considerations of common features of populist movements in the context of party politics exposes is that populism is most of all a tactic to gain power for seizing, retaining, concentrating, or eventually displacing institutional power - or eventually a tool to exercise power. Populism is therefore not so much a matter of substance, but of form. Indeed, although liberal by heart, the human rights movement, too, has on occasions adopted tactics that might be regarded as populist. One such examples is 'naming and shaming', a media pillory aimed at galvanising the sentiments of people to provide strength and legitimacy to a cause or campaign against a given practice or government. ${ }^{53}$ Naming and shaming can steer strong emotions and it often results in an ideological 'war of

\footnotetext{
50 The idea of 'malady' is borrowed from Revelli, M., Populismo 2.0 (Populism 2.0), Einaudi, 2017.

${ }^{51}$ The expression has become frequent under US President Donald Trump. Cf. inter alia, (pro), Douthat, R., 'Under Trump, the Swamp is Draining', The New York Times, December 1'st, 2018; (contra), Olen, H., 'Trump Didn't Drain the Swamp. Supporters Are Starting to Notice', Washington Post, September 11 2018.

52 For an analysis of the widespread phenomenon, Stokes, S., Political Clientelism, Oxford University Press, 2011.

${ }^{53}$ There is a vast literature both in favor and critical to the practice. For a broader account in the general practice of international relations, Friman, H., The Politics of Leverage in International Relations: Name, Shame, and Sanction, Palgrave Macmillan, 2015. On the limits of 'naming and shaming', Domínguez-Redondo, E., 'The Universal Periodic Review -- Is There Life Beyond Naming and Shaming in Human Rights Implementation?', New Zealand Law Review, 4 (2012), 673-721.
} 
trenches', that is: 'us versus them', 'victims versus perpetrators'. ${ }^{44}$ Similarly, human rights actors have enhanced their power through what could be regarded as populist tool: just like populist movements claim to speak for 'the people' as a whole, human rights claim to be acting in the name of 'humanity'. 55

Speaking on behalf of either the people or humanity is a rhetorical populist tactic to enhance the sense of legitimacy, which often allows passing and/or disguising unpopular measures. ${ }^{56}$ For example, populist movements across the Western hemisphere have been successful in leveraging the discontent of the uncompensated losers of the increasingly sophisticated mechanisms of the political economy of the world. But the discontent of increasingly struggling workers, either unemployed or underpaid, has been used to promote protectionist trade tariffs at the advantage of national businesses. The frustration of a disappearing middle class has served to pass tax 'reforms', that is, tax cuts that benefitted mostly corporations and shareholders. ${ }^{57}$ In other words, populist tactics and tools are designed to serve particular agendas of those in power. In that, populism is certainly a very important red flag, an indicator that should no doubt attract the attention of the human rights movement. However, the risk is to engage with populism as if populist tactics were themselves the problem, as if the problem was one of form and/or procedures rather than actual substance. Instead, it is crucial to engage with the particular agenda that makes use of populist tactics. It seems plausible to suggest that the main agenda behind populist

\footnotetext{
54 Meister, R., 'Human Rights and the Politics of Victimhood', Ethics and International Affairs, 16:2 (2002), 91-108 (victimhood is functional to de-politicisation and it generates polarisation and resentment, thus paving the way for more conflictuality). More comprehensively, Simonsen, K., \& Kjærgård, J. (eds.), Discursive Framings of Human Rights: Negotiating Agency and Victimhood, Birkbeck Law Press, 2017.

${ }^{55}$ Inherent in this shared stance is the sense of moral superiority. Cf. Beitz, C., 'Human Rights as a Common Concern' American Political Science Review, 95:2 (2001), 269-282 (human rights as standard to evaluate governments and institutions). Beitz embraces the view for which human rights are de facto a global moral standard, which implicitly requires moving from an assumption of self-proclaimed moral superiority.

${ }^{56}$ Human rights and populist movements equally promise to vindicate the powerlessness of individuals, groups, and peoples against perceived injustices. Where they might differ, depending on the populist movement in question, is in identifying victims and injustices: for example, while human rights organization rightly side with the thousands of migrants crossing the Mediterranean Sea, the leader of the Italian populist movement Lega Nord presented Italian citizens as victims of migration.

57 See, for the United States, the Tax Cut and Jobs Act ('An Act to provide for reconciliation pursuant to titles II and V of the concurrent resolution on the budget for fiscal year 2018'), Public Law No. 115-97, 2017. Read further, August, J.D.,' Tax Cuts and Jobs Act of 2017 Introduces Major Reforms to the International Taxation of U.S. Corporations', The Practical Tax Lawyer, 32:2 (2018), 43-54.
} 
movements, on both the left and the right, is largely nationalist. Therefore, the challenge is less about populism as such than it is about nationalism.

\section{2... and on Nationalism}

The issue that human rights scholars and advocates have with the prevailing political atmosphere cannot be just about populism per se. Rather, it seems that the issue is the substance of most current populist movements, namely nationalism. Indeed, human rights seem to be more antagonistic to nationalism - or at least some "deviant" versions of it - than they are to the empty form of populism. Although human rights cannot avoid a certain degree of entanglement with nationalism, for example in promoting self-determination, much of the history and institutional development of contemporary human rights is intertwined with curbing the potential brutality of nationalism and the nation state. In other words, the tension arises when nationalist rhetoric and programs drift into authoritarianism, fuelling social resentment, xenophobia, or even persecution, as happens in the current environment where human rights are needed in their original function in protecting minorities that nationalist rhetoric villainises. ${ }^{58}$

Nationalism is hardly a homogenous phenomenon, however. Just like for populism, the range and variety of nationalist movements is broad, as it includes people situated along the whole political spectrum, from right to left. ${ }^{59}$ Mapping the whole spectrum of contemporary nationalist movements and agendas is beyond the scope of the present work. The aim of this part is to question how nationalist narratives have become more persuasive and appealing than human rights. One possible answer is that human rights do not offer effective enough answers to some of the anxieties and preoccupations people confront in their daily lives. Here we encounter an issue raised by Nagaraj and Dudai in their responses to Alston. For the human rights enterprise and movement have become highly

\footnotetext{
${ }^{58}$ A first wave of international human rights instruments after World War II was designed to ensure protection to national minorities against the abuses of governments. This was indeed the basis for the Convention on the Prevention and Punishment of the Crime of Genocide, United Nations, 1948. See, Vrdoljak, A.F., 'Human Rights and Genocide: The Work of Lauterpacht and Lemkin in Modern International Law', European Journal of International Law, Vol. 20:4 (2009), 1163-1194.

59 Similarly problematizing but also defending the usefulness of 'populism' as comprehensive analytical category, Brubaker, R., 'Why Populism?', Theory E Society, 46:5 (2017), 357-385.
} 
bureaucratised and embedded within the very system they were supposed to contest. Human rights advocates have been used to speak truth to power, ${ }^{60}$ but to the dismay of some activists, the human rights movement is today associated with those very elites that have become target of relentless criticism. Human rights are accused of being a regime of governance, an expert language translating vague political agendas into administrative goals, for which human rights experts negotiate, measure, and monitor the progresses of a sophisticated but self-referential international bureaucracy. ${ }^{61}$

The embeddedness is problematic for at least three reasons. First, the human rights movement has traditionally regarded itself as external to power, thus escaping accountability. Secondly, as the embeddedness is also cultural, there is a further bias in favour of measures or solutions that double down on the existing system and ideology. ${ }^{62}$ Finally, a position of embeddedness makes it more challenging to answer Dudai's call to explore and understand the root causes of a widening popular discontent, which ultimately results in growing support for nationalist platforms. In the part nationalist movements attack international organizations and elites, the risk is for the human rights movement to engage into an ideological struggle to reaffirm the moral high ground of human rights against nationalist agendas. Although there is merit to that battle, it would fail to duly explore the reason why of nationalism, thus ignoring the anxieties and preoccupations of the very people the human rights movement aspires to speak for.

One reason why nationalisms might appeal to large parts of the population throughout the Western hemisphere is that they promise those forms of belonging and internal solidarity

\footnotetext{
${ }^{60}$ Kennedy, Dark Side of Virtue, p. xvi. For a collection of stories on human rights activism, Kennedy, K., Adams, E., \& Richardson, N., Speak Truth to Power: Human Rights Defenders Who Are Changing Our World, Umbrage Editions, 2005.

${ }^{61}$ For a broader critique of international expertise (not limited to human rights), Easterly, W., The Tyranny of Experts: Economists, Dictators, and the Forgotten Rights of the Poor, Basic Books, 2013.

${ }^{62}$ From climate change to inequalities, the answers they often provide often consist of simply doubling down on existing systems. For example, at last year's Davos meeting, the envisioned solutions were 'more technology' and 'better education'. Long, H., '"The Aristocrats Are Out of Touch": Davos Elites Believe the Answer to Inequality is Upskilling', The Washington Post, January $26^{\text {th }}, 2019$. A summary of the main theme discussed at the forum is available on their website: www.weforum.org/focus/davos-2019 (last access, August 7th, 2019). UNICEF rephrased business 'non-solutions' as if they were the youth's actual demands. UNICEF, 'Young People to Davos: More Jobs, Better Education', Press Release, January 21st, 2019. Available at: www.unicef.org/press-releases/young-people-davos-leaders-more-jobs-better-education (last access, August $7^{\text {th }}$ 2019).
} 
that globalisation has progressively eroded. In perhaps different ways, nationalist platforms on both the left and the right put particular stress on the idea of belonging, on identity. However, they also play an often-times racialized ethno-nationalist identity against solidarity. Nationalist movements have indeed promoted narratives that confine and thus displace the role of solidarity by presenting solidarity as the argument of those in favour of assisting and welcoming migrants and refugees. This is not a tension between national versus global solidarity, for the alleged defence of some national identity is used to erode solidarity at every level. At the same time, governments have been outsourcing solidarity to private initiatives, causing civil society to become more and more dependent on philanthropy (i.e., philanthropic capitalism). ${ }^{63}$ Therefore, the identitarian argument of the nation is used today not to empower institutions and enhance forms of solidarity between members of the same national community, 64 what is normally referred to as 'patriotism', 65 but instead to undo large portions of the welfare state and to enable a militarised form of territoriality to contrast alleged 'invasions' of undeserving migrants. That is, nationalist movements are deliberately attacking statehood and the entailed principle of solidarity. ${ }^{66}$

Nationalist movements are using populist struggles to take over the state with the apparent aim of undoing it. On the one hand, migration is mixed with terrorism in order to justify an increase in spending on military, police, and surveillance. On the other, migration also offers an argument to cut back on welfare provisions. At a deeper level, the objective appears that

\footnotetext{
${ }^{63}$ See, e.g., Gaudiani, C., The Greater Good: How Philanthropy Drives the American Economy and Can Save Capitalism, Henry Holt, 2003; similarly, Bishop, M., \& Green, M., Philanthro-Capitalism: How the Rich Can Save the World, Bloomsbury Press, 2008 (arguing philanthropy is not charity but a form of social investment that can improve capitalism further). Ács, Z., Why Philanthropy Matters: How the Wealthy Give, and What It Means for Our Economic Well-Being, Princeton University Press, 2013 (suggesting the role of philanthropy is underestimated. It implicitly accepts that philanthropic capitalism is an American ideology increasingly spread on a global scale). 'Philanthropic capitalism' has been criticised for establishing forms of dominance, dependency, and pseudo-colonialism, Wilson, J., 'Fantasy Machine: Philanthrocapitalism as an Ideological Formation', Third World Quarterly, 35:7 (2014), 1144-1161; and for creating dysfunctional responses, especially when it comes to public health, inter alia, Clark, J. \& Mcgoey, L., 'The Black Box Warning on Philanthrocapitalism', The Lancet, 38:19 (2016), 2457-2459.

${ }^{64}$ Anderson, B., Imagined Communities: Reflections on the Origin and Spread of Nationalism, Verso, 2016. One interesting shift has been that of locating solidarity at the global level, antagonistically leveraging solidarity against nations. See, e.g., Goodman, J. \& James, P., Nationalism and Global Solidarities: Alternative Projections to Neoliberal Globalisation, Routledge, 2007.

65 Cf. Murray, J., 'Nationalism, Patriotism, and New Subjects of Ideological Hegemony', Journal of Philosophy, 6:14 (2011), 16-30.

${ }^{66}$ On the synergies and tensions between contemporary nationalism and neoliberalism, Harmes, A.,'The Rise of Neoliberal Nationalism', Review of International Political Economy, 19:1 (2012), 59-86.
} 
of dissolving the public sphere and its guarantees in order to unleash private forms of power - a remarkably regressive trend that goes to show that no social or political achievement should ever be taken for granted. The struggle is thus about the typology of the state: a minimalist and perhaps authoritarian 'nocturne guardian' or a welfarist state? Solidarity (which is just another name for 'brotherhood') is the forgotten term from the revolutionary triad 'freedom, equality, solidarity'. Hence, the human rights movement could reappropriate the notion of solidarity to vindicate its original promise. To the extent nationalist movements are today undermining social welfare and replacing internal solidary with its boorish surrogate, that is, xenophobia, then human rights are better placed to promote a program that aims to re-establish solidarity relations between people within and beyond their national communities.

The widespread use of populist tactic to revive nationalist themes exposes an ongoing struggle to assert or consolidate dominance. The human rights movement needs to accept and embrace its position and role in a field of struggles - struggles that are political in nature, something that human rights proponents have been fairly reluctant to acknowledge. ${ }^{67}$ The human rights project does not consist of self-evident universal truths, but it rather pursues specific political interests that inevitably clash with those of others. Privileges of whatever nature are never given up without significant resistance and thus socio-political struggles. ${ }^{68}$ But many in the human rights movement hardly see themselves as actors seeking or leveraging power; ${ }^{69}$ instead, they have adopted a position of 'watchdogs', 70 which ultimately betrays a certain degree of embeddedness within the very system they should challenge.

\footnotetext{
${ }^{67}$ Kennedy, Dark Side of Virtue, p. xvi et passim.

${ }^{68}$ For an interesting account on inequalities throughout history, see, Scheidel, W., The Great Leveler: Violence and the History of Inequality from the Stone Age to the Twenty-First Century, Princeton University Press, 2017 (arguing that inequalities have historically decreased after wars, revolutions, dissolution of civilizations, and pandemics, which often occurred because of resistance to reforms for better wealth redistribution).

69 Koskenniemi, 'Alston Rocking the Human Rights Boat'

70 See, Risse, K.T., Ropp, C.S. \& Sikkink, K. (eds.), The Persistent Power of Human Rights: From Commitment to Compliance, Cambridge University Press, 2013 (the volume contains a number of interventions that track the transformation of human rights from grassroots advocacy to compliance and accountability).
} 


\section{Human Rights and the Political Economy of the World}

The previous section that a path forward for the human rights movement, and a possibility of gaining back lost ground from nationalist populist, may be to return the notion of solidarity to its position of prominence within the movement. We will return to this theme in the concluding section of the article. Before that, however, there is another point that has to be made to complete the picture. For although we argued above that the true antagonistic opponent of the human rights movement might be nationalism, rather than populism per se, it is worth noting that states and governments play today only partial functions within a broader political economy of the world. Prophets of globalisation have used this to suggest that nation states - and perhaps statehood as such - are doomed to fade. But while states have been progressively emptied of their political significance, they have not disappeared. They have been turned into security devices to protect private property, international investments, and other interests. ${ }^{71}$ For the postcolonial world has bypassed sovereign equality through a political economy that fundamentally perpetuates patterns of dominance.

In thinking about the role of potential of human rights in the context of this material reality, Alston is once again a useful interlocutor. As discussed in Section 2, Alston suggests that there could be a straightforward remedy to this situation, namely to more robustly include social and economic rights in the human rights programme. Alston thus invites human rights advocates to double down on a consolidated recipe: recognition, institutionalisation, and accountability.72 Alston's intervention is important because he is certainly correct to point out that social and economic rights have been for long marginalised for the most diverse reasons. ${ }^{73}$ Perhaps most importantly, many have been content with a mere promise of 'progressive realisation' that never quite materialised, social and economic rights having

\footnotetext{
${ }^{71}$ Kennedy, D., 'Law and the Political Economy of the World', Leiden Journal of International Law, 26:1 (2013), 7-48.

72 This is also the view of Sikkink, K., The Justice Cascade: How Human Rights Prosecutions Are Changing World Politics, W.W. Norton \& Co., 2011. More recently, Sikkink, K., Evidence for Hope: Making Human Rights Work in the 21st Century, Princeton University Press, 2017.

${ }^{73}$ Their status as actual rights has been put under question. See, Cranston, M., "Human Rights: Real and Supposed", in Raphael, D.D. (ed.), Political Theory and the Rights of Man, Indiana University Press, 1967, pp. 4351; Cranston, M., 'Are There Any Human Rights?', Daedalus, 112:4 (1983), 1-17.
} 
been labelled as more expensive and more difficult to both realise and enforce, compared to civil and political rights. ${ }^{74}$ Unsurprisingly, then, towards the end of the Millennium, a general frustration with the ineffectiveness of human rights to deliver on material needs brought countries from the global South to switch focus onto development. ${ }^{75}$

Where we disagree with Alston, however, is in his proposition that doubling down on the existing human rights project, but with extra attention on economic and social rights, is the best path forward. This is so for at least two reasons. First, human rights have become embedded in the political economy of the world: without sorting out their entanglement first, there is the risk of achieving the opposite end to the one allegedly sought. The second is the unwillingness or, more worryingly, inability on the part of the human rights movement to engage with the complexity and sophistication of the political economy of the world. The present Section thus discusses two problems: 'helplessness' and 'complicity'. While international lawyers have been paying greater attention to the significance of political economy and the role of international law in it, human rights have yet to seriously engage with this area. This Section aims to provide an initial input to what should possibly become a more widespread research agenda.

\subsection{The 'Helplessness' Problem}

In contemporary societies, matters of distribution and redistribution are incredibly complex $;^{76}$ different narratives tend to reduce the problem to one or the other cause, often on the basis of some underlying ideological view. ${ }^{77}$ The increasing sophistication of the

\footnotetext{
${ }^{74}$ On the attempts, failures, and successes of economic and social rights in reshaping the postcolonial world, Wills, J., Contesting World Order? Socioeconomic Rights and Global Justice Movements, Cambridge University Press, 2017 (the account lean more towards the future potential than effective success in the past).

75 The relation between human rights and development has become a field of its own. As an introduction, inter alia, Langford, M., Sumner, A. \& Ely Yamin, A. (eds.), The Millennium Development Goals and Human Rights: Past, Present and Future, Cambridge University Press, 2013.

${ }^{76}$ For an introduction, see, Galbrath, J.K., Inequality: What Everyone Needs to Know, Oxford University Press, 2016. For Galbrath, there are two fundamental issues: first, the realisation that 'wealth is power' - and wealth is not just about income (p. 151); second, political institutions 'remain a bulwark against inequalities' (p. 111). 77 For example, referring to the U.S. political landscape, Jonathan Rothwell claims that the Left blames corporations while the Right points at unfair trade practices (and in times of populism, often times the arguments switch from one aisle to the other). Instead, he argues that the problem lies in the monopolization of key services. In this respect, it's unclear why he regards the Left's revived interest for antitrust as a limit. Cf. Rothwell, J., A Republic of Equals: A Manifesto for a Just Society, Princeton University Press, 2019. Rothwell
} 
political economy of the world requires human rights to engage with technical aspects of law and their socio-economic impacts. But are human rights properly equipped for the task? Or to put it differently, is giving a more prominent role to social and economic rights, but otherwise doubling down on the existing project enough? Relative distribution and redistribution of wealth both within and among countries have traditionally been determined by at least four elements, namely: taxes, labour, trade, and prices. The problem is here twofold. On the one hand, these instruments are today largely ineffective in generating distribution and redistribution because they have been appropriated for achieving the diametrically opposite aims, that is, extraction of gains and concentration of wealth. On the other hand, human rights appear 'helpless' in this regard, for the human rights agenda rarely tackles any of such issues.

(a) Until very recently, human rights seemed to have little or nothing to say about taxes. ${ }^{78}$ Recent 'tax reforms' - that is, tax cuts for corporations and the wealthiest - have boosted buy-backs and dividends. But while stock markets have soared at record levels, ${ }^{79}$ wages have been stagnant ${ }^{80}$ despite several Western countries register increased productivity and some of the lowest unemployment rates since at least the 2007-2008 financial crisis. ${ }^{81}$ In other words, people work more (and more productively) to earn less. ${ }^{82}$ The contrast between financial gains and waged labour is of great importance. As Thomas Piketty has shown at length, one key cause - if not the key cause - of inequality has for centuries been the disparity in ownership of

also notes that the problem lies less in inequalities as such than in what society at large perceives as 'unfair' inequalities.

78 Until recently, literature in this area was scarce. The theme has been nonetheless gaining momentum in recent years. See, Beckett, P., Tax Havens and International Human Rights, Routledge, 2018; Alston, P. \& Reisch, N. (eds.), Tax, Inequality, and Human Rights, Oxford University Press, 2019; Davis, D., 'Taxation and Equality: The Implications for Redressing Inequality and the Promotion of Human Rights', Humanity, 10:3 (2019), 465478.

${ }^{79}$ Egan, M., 'Market Milestone: This Is the Longest Bull Run in History', CNN Business, August 22nd, 2018. Also, Holmes, F. \& Great Speculation, 'Can the Bull Market Run Another 10 Years?', Forbes, March 7th, 2019.

80 Limitedly to the United States, Mishel, L., Gould, E. \& Bivens, J., 'Report: Wage Stagnation in Nine Charts', Economic Policy Institute, January $6^{\text {th }}, 2015$. See also, Organization for Economic Cooperation and Development, Employment Outlook 2019: The Future of Work, OECD, 2019 (noting that unemployment has become less of an issue than stagnating wages). More recently, Stiglitz, J., 'Progressive Capitalism Is Not an Oxymoron', New York Times, April 19th, 2019. The theme is nonetheless controversial, as more liberal outlets contends the indicators and measures adopted to determine wage stagnation are misleading. Inter alia, Strain, M.,' The Story of Stagnating Wages Was Mostly Wrong', Bloomberg, May 15th, 2019; Gramm, P. \& Early, J., 'The Myth of "Wage Stagnation"', The Wall Street Journal, May 19th, 2019.

81 For the United States, refer to the Employment Situation Survey by the Bureau of Labour Statistics at https://www.bls.gov/news.release/empsit.nr0.htm (last access, August $7^{\text {th }}$, 2019). For the European Union, data on employment are available on Eurostat at https://ec.europa.eu/eurostat/statisticsexplained/index.php/Unemployment_statistics (last access, August 7th, 2019).

82 To this point, one should further add the effects of automation and robotization. A recent proposal calls for taxing the work of machines. Cf. Rubin, R., 'The "Robot Tax" Debate Heats Up', The Wall Street Journal, January $8^{\text {th }}, 2020$. 
financial assets. The return on capital has been steadily higher than the return on paid labour. ${ }^{83}$ While there are proposals to impose taxes on financial transactions, ${ }^{84}$ there are currently only minor taxes on capital gain - when taxation applies at all, for double taxation loopholes or tax minimisation strategies often allow to avoid taxes entirely. ${ }^{85}$ Furthermore, as inheritance taxes are either lifted or eluded in several rich countries, the result is a progressive concentration of wealth over time. ${ }^{86}$ In contrast, workers are today excluded from acquiring property once accessible to many, such as homes and cars; instead, higher prices, limited access to credit, and new market structures force workers into renting or leasing, for which they never acquire assets or equity. As Katharina Pistor has recently noted, ${ }^{87}$ financial assets are pure legal creations: they do not exist without law - a law backed by a state willing and able to enforce it. It is thus curious how states are today effective in enforcing the set of contracts and other legal devices supporting the operations of financial markets, but seem unable to impose appropriate taxation on them. It is also interesting to note how firms and corporations have significantly improved the ability of states to tax labour and income, ${ }^{88}$ how states have repeatedly designed fiscal advantages, such as tariffs, to protect national firms and businesses, but for some reason the widespread belief is that states struggle to tax large transnational corporations. Insofar, the human rights movement has neglected the field of taxation. But taxes and rights are the fundamental skeleton of any state, for they decide the fundamental distribution of power and opportunities. As Alston and Reisch have recently noted: 'both taxation and human rights law are, in their essence, about the relationship between the individual and the state'. ${ }^{89}$ Their recent volume is a fundamental first step, as it acknowledges the fundamental interconnection between taxes and human rights in at least two respects: first, taxes should allow a relative redistribution of wealth,

83 Piketty, Capital in the Twenty-First Century. Those who own financial assets have been enjoying growing capital gains, whereas workers have suffered a progressive erosion of their wages. Financial assets are also tied up with collaterals, that is, with material assets (and vice versa). Hence, finance can leverage material wealth as well as expand it significantly.

${ }^{84}$ A first proposal was advanced by James Tobin, which has originated the name of 'Tobin Tax'. See, Tobin, J., 'A Proposal for International Monetary Reform' Eastern Economic Journal, 4:3/4 (1978), 153-159; reprinted, Tobin, J., 'A Proposal for Monetary Reform', Eastern Economic Journal, 29:4 (2013), 519-526.

85 The proposal for a tax on financial transactions, first put forward by the European Commission in 2011, is now gaining new traction because of the impact of high-frequency trading on security markets. See, Chung, K.H. \& Lee, A.J., 'High-Frequency Trading: Review of the Literature and Regulatory Initiatives Around the World', Asia-Pacific Journal of Financial Studies, 45:1 (2016), 7-33. Traditionally reluctant actors are more willing to accept a levy, which is presented as making markets more efficient while contributing to social justice, e.g., Buckley, R.P., 'Introducing a 0.05\% Financial Transactions Tax as an Instrument of Global Justice and Market Efficiency', Asian Journal of International Law, 4:1 (2014), 153-167.

86 Wagner, R., Death and Taxes: Some Perspectives on Inheritance, Inequality, and Progressive Taxation, American Enterprise Institute for Public Policy Research, 1973. More recently, Beckert, J., Inherited Wealth, Princeton University Press, 2008.

87 Pistor, K., The Code of Capital: How the Law Creates Wealth and Inequality, Princeton University Press, 2019.

88 Braithwaite, J., Regulatory Capitalism: How It Works, Ideas for Making It Work Better, Edward Elgar, 2008, pp. 23-24. Braithwaite describes the corporatization of the capitalist economy, suggesting how: 'one effect of the corporatization of capitalism in the twentieth century was that it made it easier for the state to collect taxes'. The contrast between corporate capitalism and middle-class capitalism is one of the themes dominating the contemporary political debate in the democratic primaries. See, e.g., The Economist, 'Elizabeth Warren Wants to Remake American Capitalism', The Economist, October 24th 2019.

${ }^{89}$ Alston \& Reisch (eds.), Tax, Inequality, and Human Rights, p. 19. 
rather than income, thus limiting social marginalisation and exclusion; second, tax revenues are essential to finance those infrastructures and services that states are called to put in place in order to realise positive and negative human rights obligations. ${ }^{90}$ Alston and Reisch argue that 'tax and human rights are inherently intertwined and face a common challenge today: the reconceptualization of what constitutes a just society and the social good' ${ }^{91}$ Their analysis engages with the liberal debate on whether civil rights or taxes are more effective in redistributing wealth and power in society, ${ }^{92}$ for taxes imply a greater role for the state, whereas rights should leave broader margin to private initiatives. Alston and Reisch do challenge the growing trend of 'privatisation' and they envision human rights as possible standard of fairness and legitimacy for taxation. However, they take for granted the power of states to collect taxes. The approach is therefore somewhat 'moral', for the underlying assumption is that paying taxes to states is 'good' for as long as states use that money to fulfil their human rights obligations. There are then 'good' states and 'bad' states, 'good' corporations and 'bad corporations'. What is missing is a more radical analysis on how, historically, the power of taxation has been exercised. The history of taxes is indeed a gloomy one: for taxation has been a key strategy of subjugation and extraction of wealth, of administration of populations and oppression of social groups, of war-making, and so forth. ${ }^{93}$ Hence, human rights should not just offer a formal analysis for the evaluation of fiscal policies: instead, the tension for human rights and taxes ought to offer the ground for a more radical and structural debate on the nature of the state and its functions. ${ }^{94}$

(b) Human rights seem to have relatively little to say about labour. Not only human rights have little to say about labour, but they also interpret labour in fairly liberal terms. In abstract economic models, the free negotiation of wages in exchange for labour should guarantee a relative redistribution of wealth. In the real world, workers have been suffering an erosion of both rights and wages. It is not all about technology replacing workers, however. Several interconnected factors have contributed to the weakened position of workers. In the first place, the current model of globalisation guarantees the

\footnotetext{
${ }^{90}$ Avi-Yonah, R.S., 'Globalization, Tax Competition, and the Fiscal Crisis of the Welfare State', Harvard Law Review, 113:7 (2000), 1573-1676 (suggesting developed nations are in dire need of tax revenues).

${ }^{91}$ Alston \& Reisch, ibid.

92 On this point, see, Kaplow, L. and Shavell, S.' Why the Legal System is Less Efficient than the Income Tax in Redistributing Income', The Journal of Legal Studies, 23:2 (1994), 667-681 (challenging the neoliberal assumption of the Chicago School about liberal rights as most effective mean in redistributing income and wealth).

93 The fact that virtually all states today print their own currency is a consequence of the historical difficulty for sovereigns to raise taxes to pay for their wars. To this day, a major share of tax revenues ends up paying for military expenses. For an extensive analysis on money, taxes, and power, see, Desan, C., Making Money: Coin, Currency, and the Coming of Capitalism, Oxford University Press, 2014.

94 Alston \& Reisch's volume is an impressive collection of high-quality contributions. Assessing and discussing such work is beyond the scope of the present contribution. We limit our analysis to repeat how Alston tends to offer solutions that might not be as radical as they should be, and how the role of the state is being revived by the very human rights that for long espoused a liberal narrative in favor of minimizing the role of states.
} 
free circulation of capital and the relatively frictionless circulation of goods, but it restricts and regulates the mobility of workers. ${ }^{95}$ Controlling the circulation of labour force is functional to depress wages. ${ }^{96}$ Indeed, one 'mystery' of the liberal capitalist system is that while the free circulation of capital and goods increases their respective valuations, in those instances in which labour force is allowed to move, it is more likely to depress wages than to increase them. That is, the circulation of capital and labour generates completely opposite effects. Far from being a 'natural' law of economics, this situation is the product of a legal landscape that allocates gains and losses: a stronger promotion of investors' interests translates into an increasingly weak protection of workers' rights and wages. In the attempt of attracting investment in the form of either capital or business, different jurisdictions compete in offering advantageous tax regimes for investors and companies, shifting taxation burdens from corporate revenues to income from labour. Therefore, workers find themselves to be losers in at least three interconnected ways: stagnant or decreasing wages, higher taxation, but less public services. Indeed, the erosion of tax revenues has made it harder for countries to offer those public services - many of which contribute to the fulfilment of human rights obligations - that alleviate the conditions of the lower class while enabling the middle class (e.g., free health care and free education, effective public transportation, etc.). In the international compartmentalisation of functions, labour falls within the competences of the International Labour Organisation, ${ }^{97}$ which has drafted and ratified about two hundred conventions over time, mostly addressing the conditions of workers on the workplace. But while labour is safer and perhaps greener, ${ }^{98}$ it is becoming more and more challenging to find well-paid positions. Furthermore, a significant share of these standards and regulations are part of trade strategies that aim to preserve the dominance of some actors over others. Human rights are not only rather toothless under these

\footnotetext{
${ }^{95}$ Unger, R., Free Trade Reimagined: The World Division of Labor and the Method of Economics, Princeton University Press, 2007.

${ }^{96}$ Although the measure has broader political objectives, the 'Hukou' system in China is one example of how limiting the free movement of workers is functional to control the cost of labour. See, Wang, H., Guo, F., \& Cheng, Z., 'A Distributional Analysis of Wage Discrimination Against Migrant Workers in China's Urban Labour Market', Urban Studies, 52:13 (2015), 2383-2403; Song, Y., 'Hukou-Based Labour Market Discrimination and Ownership Structure in Urban China', Urban Studies, 53:8 (2016), 1657-1673.

${ }_{97}$ Maul, D., Human rights, Development, and Decolonization: The International Labour Organization, 1940-70, Palgrave Macmillan, 2012 (noting the increasing tension between competing priorities).

${ }_{98}$ Compa, L., \& Diamond, S., Human Rights, Labor Rights, and International Trade, University of Pennsylvania Press, 1996.
} 
conditions, but as Vidya Kumar has pointed out, the convergence of human rights and labour rights - i.e. the claim that "labour rights are human rights" - depoliticizes important conflicts in international law and thus hides the power disparities that labour law has been so good at revealing. If labour rights have traditionally focused on the relations between the worker and the employer, human rights are focused on the relations between the individual and the state. In a similar vein, if labour law has focused on power disparities, human rights emphasize the imagined equality of all human beings. Hence, recasting labour rights as human rights and thus reimagining the state as the antagonist of the worker and workers and employers as equals may deprive labour rights of their radical edge and shift focus away from concrete power relations of power and inequalities between workers and employers. ${ }^{99}$

(c) Trade is particularly impermeable to human rights concerns. At the same time, trade has enormous distributional consequences. In its current form, trade tends to concentrate gains in the hands of the few, while trade's promise of a better future for all brings the paradoxical outcome of marginalising democracy.100 The contemporary 'free trade regime' is an expression of sectorial interests in developed countries, the interests of powerful corporations that successfully lobbied their respective government, translated into global rules. ${ }^{101}$ Although the global free trade regime is allegedly crumbling, ${ }^{102}$ the power behind it is stronger than it ever was. Despite significant economic growth, the volumes of international trade are decreasing because most trade occurs within corporations along so-called global value chains. ${ }^{103}$ Built through instruments of

\footnotetext{
${ }_{99}$ Kumar, V., 'Rethinking the Convergence of Human Rights and Labour Rights in International Law: Depoliticisation and Excess,'in Ruth Buchanan and Peer Zumbansen eds, Law in Transition: Human Rights, Development and Transitional Justice (Hart Publishing, 2014).

${ }^{100}$ Cf. Rodrik, D., The Globalization Paradox: Democracy and the Future of the World Economy, W.W. Norton \& Company, 2011, p. xix.

101 Stiglitz, J., 'Social Justice and Global Trade', Far Eastern Economic Review, 169:2 (2006), 18-22; Rodrik, D., Straight Talk on Trade: Ideas for a Sane World Economy, Princeton University Press, 2018.

102 Stiglitz, J., Globalization and Its Discontent Revisited: Anti-Globalisation in the Era of Trump, W.W. Norton \& Company, 2018.

103 Cf. Lund, S., Manyika, J., Woetzel, J., Bughin, J., Krishnan, M., Seong, J. \& Muir, M., Globalization in Transition: The Future of Trade and Value Chains, McKinsey Global Institute, 2019. Global Value Chains have a paradoxical combined effect: on the one hand, they make the world more interdependent; on the other, they also turn it more private and unequal. On the former aspect, see, Cattaneo, O., Gereffi, G., \& Staritz, C., Global Value Chains in a Postcrisis World: A Development Perspective, World Bank, 2010 (interdependence, however, does not mean that weaknesses and risks are evenly distributed along the chain).
} 
corporate law and private law, global value chains can be brutal: they allow corporations to achieve fiscal elusion, social dumping, 104 and avoid a series of other 'externalities' (e.g., compliance to labour and/or environmental regulations) by shifting these 'costs' onto less powerful actors or society at large. A growth in internal trade means that the allocation of resources is less concerned with efficiency and more with preserving the dominant position of the corporation. Indeed, trade is a field in which actors seek dominance. Some suggest that whichever position of dominance comes with costs to defend reputation. ${ }^{105}$ Although corporations might be sensitive to their reputation, they opt for private forms of self-regulation (i.e., Corporate Social Responsibility), ${ }^{106}$ for which human rights issues become part of a broader strategy for competitive advantage and marketing. ${ }^{107}$ At the same time, states have increasingly shied away from leveraging antitrust laws, allowing some corporations to attain a virtually unrestrained global domain. ${ }^{108}$ As the economic and trade competition with China and South East Asian countries has intensified, developed economies have not only reversed their approaches to free trade, at times revamping protectionism, but also carefully balanced the risks of cracking down on dominant or rent positions: while this might favour national

104 Aguiar De Medeiros, C., \& Trebat, N., 'Inequality and Income Distribution in Global Value Chains', Journal of Economic Issues, 51:2 (2017), 401-408 (arguing that there are two forms of competition, one at the top of the chain and one at the bottom: the latter is about low wages, the former about the ability to protect intellectual property and capture gains). Stringer, C., \& Michailova, S., 'Why Modern Slavery Thrives in Multinational Corporations' Global Value Chains', Multinational Business Review, $26: 3$ (2018), 194-206 (with the rise in competition at the lower end of the chains GVCs favour forms of slavery).

105 Wheeler, S., 'Global Production, CSR and Human Rights: The Courts of Public Opinion and the Social Licence to Operate', The International Journal of Human Rights, 19:6 (2015), 757-778 (suggesting 'naming and shaming' could be effective in influencing corporations).

106 Ruggie, J., 'Report of the Special Representative of the Secretary-General on the Issue of Human Rights and Transnational Corporations and Other Business Enterprises', Netherlands Quarterly of Human Rights, 29:2 (2011), 224- 253; also, Ruggie, 'Business and Human Rights: The Evolving International Agenda', The American Journal of International Law, 101:4 (2007), 819-840; Ruggie, 'Protect, Respect and Remedy: A Framework for Business and Human Rights', Innovations: Technology, Governance, Globalization, 3:2 (2008), 189-212; Ruggie, 'Business and Human Rights: Together at Last?', Fletcher Forum of World Affairs, 35 (2011), 117-123; more recently, Ruggie, Just Business: Multinational Corporations and Human Rights, W.W. Norton \& Company, 2013. The UN has issued the so-called Ruggie's Guidelines or Guiding Principles on Business and Human Rights, Office of the High Commissioner for Human Rights, 2001 (HR/PUB/11/04).

107 Scheper, C., "'From Naming and Shaming to Knowing and Showing": Human Rights and the Power of Corporate Practice', The International Journal of Human Rights, 19:6 (2015), 1-20 (arguing that CSR proves the ability of capitalism to absorb and transform fundamental criticism). It has been recently noted how CSR have improved some aspects (e.g., child labour), while undermined others (e.g., unionization of workers), Crinis, V., 'Corporate Social Responsibility, Human Rights and Clothing Workers in Bangladesh and Malaysia', Asian Studies Review, 43:2 (2019), 295-312.

${ }^{108} \mathrm{~A}$ vocal critic of the current inertia in antitrust, $\mathrm{Wu}, \mathrm{T}$., 'Taking Innovation Seriously: Antitrust Enforcement if Innovation Mattered Most', Antitrust Law Journal, 78:2 (2012), 313-328. More recently, Wu, T., The Curse of Bigness: Antitrust in the New Gilded Age, Global Reports, 2018. 
consumers, leveraging antitrust could also harm the national interests by weakening national enterprises in times of fierce economic competition. Take the macroscopic example of Amazon: ${ }^{109}$ why would the United States target Amazon with antitrust if the danger is to weaker the overall strategic position of the country against, say, China and its analogous platform of Alibaba? The two global giants are symptomatic of some major transformations occurring in global trade: with the rise of digital platforms and a growing use of proprietary data - more or less intrusively or even abusively 'mined' to feed algorithm, the world is witnessing a new wave of monopolies. ${ }^{110}$ As the role of these digital platforms becomes more and more infrastructural, the helplessness of human rights emerges all the more evidently:111 is it just a matter of privacy and consent? ${ }^{112}$ But isn't consent already an implicit admission of asymmetrical power?

(d) Human rights actors might find it legitimately difficult to understand how to engage with prices. But prices are a crucial part of today's economy and they express the value society attributes to specific goods and services. Some major transformations of the global economy are affecting the way prices are set. For instance, digital platforms are only one side of the increasing 'virtualisation' of trade, the other side being the share of trade in intangibles, which include financial assets. Intangibles require strong protection of property, most notably intellectual property. Intellectual Property Rights (IPRs) have been globalised through the World Trade Organisation (WTO), ${ }^{113}$ as membership to the organisation is made dependant on signing up to the Agreement on Trade Related Aspects of Intellectual Property Rights (TRIPS). Engineered by the Intellectual Property

109 Khan, L.M., 'Amazon's Antitrust Paradox', Yale Law Journal, 126:3 (2017), 710-894.

110 Zuboff, S., The Age of Surveillance Capitalism: The Fight for a Human Future at the New Frontier of Power, Public Affairs, 2019. Calling for a less enabling role of international lawyers in shaping the new world of 'big data', Johns, F., 'The Deluge', London Review of International Law, 1:1 (2013), 9-34.

111 Joyce, D., 'Privacy in the Digital Era: Human Rights Online?', Melbourne Journal of International Law, 16:1 (2015), 270-285 (noting the relative inability of the UN General Assembly to cope with the complexity of the current transformations).

112 Privacy is the pillar of the European Union's approach to digital platforms and data transfer, Marc Rotenberg, \& David Jacobs. (2013), 'Updating the Law of Information Privacy: The New Framework of the European Union', Harvard Journal of Law \& Public Policy, 36:2 (2013), 605-652. Also, Johns, F. \& Joyce, D., 'Beyond Privacy: Is Prevailing Legal Debate Too Analog for a Digital Age?', Human Rights Defender, 23:3 (2014), 2426. Compliance is however insufficient, Jørgensen, R., \& Desai, T., 'Right to Privacy Meets Online Platforms: Exploring Privacy Complaints against Facebook and Google', Nordic Journal of Human Rights, 35:2 (2017), 106126.

113 Drahos P., The Universality of Intellectual Property Rights: Origins and Development, World Intellectual Property Organization, 1999. 
Committee, a coalition of thirteen CEOs from the America largest pharmaceutical, software, and entertainment companies, the TRIPS Agreement established a global regime 'that reaches deep into the domestic regulatory environment of states' under the disputable narrative that they protect inventors and human ingenuity. ${ }^{114}$ However, what IPRs actually do is to securitise investors, while allowing an unprecedented leverage in setting the prices for goods. Indeed, IPRs are an essential tool for promoting a 'subjective' theory of prices, meaning that goods are not sold at a price reflecting their production costs or societal value, but rather aiming at the highest possible price the buyer is able to pay. ${ }^{115}$ This practice dramatically affects, for instance, the cost of medicines, as pharmaceutical companies can freely set prices, often leveraging the fact that states or insurers have an obligation to cover the costs for a given pathology. ${ }^{116}$ IPRs are also effective in capturing value at the expenses of the broader supply chain, for the gains from trade are unequally distributed between labour input and the value of the licensed patent or brand. Ironically, royalties on IPRs can benefit from privileged tax treatment. ${ }^{117}$ IPRs offer an interesting and effective example of how value is extracted and accumulated: law enables the growing dominance of finance and thus the financialisation of the economy and life more broadly. Finance has become effective in capturing gains at the expenses of other stakeholders. The rise of finance corresponds with an age of globalisation, de-regulation, and inequalities. For instance, the success and prosperity of the financial sector has also corresponded to an explosion of public and private indebtedness. ${ }^{118}$ It is thus ironic how the solution to the problem is at times indicated in a more inclusive system, perhaps making credit scores to access loans 'fairer'

\footnotetext{
114 Sell, S.K., Private Power, Public Law: The Globalization of Intellectual Property Rights, Cambridge University Press 2003, p. 1. See also, Deere C., The Implementation Game: The TRIPS Agreement and the Global Politics of Intellectual Property Reform in Developing Countries, Oxford University Press, 2009.

115 Mazzucato, M., The Value of Everything: Making and Taking in the Global Economy, Penguin Books, 2018, pp. 207-228 (with particular reference to the pricing of medicines).

116 As Amy Kapczynski puts it, 'a right to medicines imbricated into this regime is plausibly regressive: it places significant strain on healthcare budgets, redistributes upwards, and provides medicines on terms largely dictated by one of the most profitable industries in the world'. Kapczynski, A, 'The Right to Medicines in an Age of Neoliberalism', Humanity Journal, 10:1 (2019), 79-107 at 81.

117 Blair-Stanek, A., 'Intellectual Property Law Solutions to Tax Avoidance.', UCLA Law Review, 62:1 (2015), 273 (arguing that against the inefficacy of tax law, changes ought to be made in intellectual property).

118 The International Monetary Fund has recently launched a Global Debt Database, accessible at: www.imf.org/external/datamapper/datasets/GDD (last access, August 7th, 2019). Although the data are still partial, it is possible to observe an increase in both public and private debt over the last decades.
} 
(i.e., financial inclusion and inclusive capitalism). ${ }^{119}$ Much of the contemporary financialised economy aims to maximise 'shareholders' value', that is, to more or less artificially increase the price of publicly traded shares. But this means privileging one group of people over others. One main challenge for human rights is then to rebalance the interests of different social groups. This might require reframing the meaning of 'value' in society, ${ }^{120}$ which would also imply redesigning the role of finance.

For better or worse, the human rights movement has so far opted for engaging in somewhat ideological battles in the public sphere, thus neglecting those more technical aspects that have allowed to erect and establish unprecedented forms of private power on a global scale. Distribution and redistribution are decided by:

'[B]y and large, private law regimes such as contract law, corporate law, tort law, property lay, tax law, intellectual property law, commercial arbitration (...) as well as a vast array of private ordering regimes and business practices, including practices to create and exploit commercial advantage as well as industry association standards, corporate codes of conduct and other business-led corporate social responsibility mechanism'.121

Therefore, the traditional human rights strategy to hold states accountable for violations of individual rights seem toothless and ill-equipped to deal with the root causes of socioeconomic inequalities in contemporary societies. One could fathom that human rights could still exercise pressure on governments to enact laws and policies to guarantee a certain degree of material equality between citizens. However, there are at least two obstacles. The first is that even in some developed countries, governments have less and less room for manoeuvre. The constraints are said to descend from the political economy of the world,

\footnotetext{
119 Fleissner, C. 'Inclusive Capitalism Based on Binary Economics and Positive International Human Rights in the Age of Artificial Intelligence', Washington University Global Studies Law Review, 17:1 (2018), 201-244 (supporting the idea of fuller employment to favour income distribution).

120 Lazonick, W., 'Profits Without Prosperity', Harvard Business Review, 92:9 (2014), 46-55. Jacobs, M. \& Mazzucato, M., Rethinking Capitalism: Economics and Policy for Sustainable and Inclusive Growth, WileyBlackwell, 2016.

${ }^{121}$ Danielsen, D., "Situating Human Rights Approaches to Corporate Accountability in the Political Economy of Supply Chain Capitalism" in Brinks, D., Dehm, J. and Engle, K. (eds.), Power to People? Private Efforts to Enforce Human Rights in Supply Chains, forthcoming 2019. It has also been argued that international private law is not necessarily antagonistic to human rights, Watt, H., 'Competition or Confluence? Private International Law and Human Rights in Global Governance', Revue Internationale De Droit Économique, 27:1-2 (2013), 59-78.
} 
but they are ultimately legal: if a government is pressed in between international investment treaties and human rights obligations, the former will likely prevail. A second obstacle is internal to the human rights movement. As Samuel Moyn has recently argued, to the extent the human rights movement has been mobilised to deal with inequalities, it has settled to easily to raising individuals above the minimum standard of sufficiency. ${ }^{122}$ In other words, it has prioritised sufficiency over equality, thus serving as an unwitting companion to the neoliberal project that has brought forth 'a golden age of the rich' ${ }^{123}$ In this respect, the human rights movement needs not only better tools to engage into the battlefield of private law, but also a different narrative to disentangle human rights from its complicity with neoliberalism.

\subsection{The 'Complicity' Problem}

The 'age of rights' has corresponded to an explosion of socio-economic inequalities and a 'golden age of the rich'. It is thus fair to question whether human rights might have played a role in that by looking at two dimensions, namely a structural and cultural aspects respectively. In contemporary debates, inequalities are directly associated with the effects of neoliberal policies. While Samuel Moyn sees no immediately interconnection between neoliberalism and human rights, thus characterising human rights as a "powerless companion' to the neoliberal project,124 Jessica Whyte has recently challenged such view, showing an ideological and structural complicity between them. Whyte indeed argues that the hegemonic versions of human rights have been turned into 'the morals of the market', 125 that is, into an effective tool for refuting socialist and postcolonial demands for greater economic equality, while upholding 'a neoliberal right to equality [as] a right of everyone to preserve their unequal wealth and power in the face of political demands for redistribution'.126 The present part does not directly engage with such debate,127 but it

\footnotetext{
122 Moyn, Not Enough.

123 Ibid., p. 58.

124 Moyn, S., 'A Powerless Companion: Human Rights in the Age of Neoliberalism', Law E Contemporary problems, 77:4 (2014), 147-169.

125 Whyte, J., The Morals of the Market: Human Rights and the Rise of Neoliberalism, Verso, 2019, p. 34

126 Whyte, The Moral of the Market, p. 24.

127 On the intellectual history of neoliberalism, see also, Slobodian, Q., Globalists: The End of Empire and the Birth of Neoliberalism, Harvard University Press, 2018.
} 
touches on themes that are relevant to it. On the one hand, the human rights language has been used to produce or strengthen some of the legal and economic structures that produce today's radical inequality. On the other, the culture and practices of the human rights movement appear to be broadly liberal, for they embrace the primacy of the private, a certain idea of economic freedom, a preference for technical expertise over politics, and so forth.

(a) A first aspect of complicity concerns the use of human rights for creating or reinforcing the legal and economic structures generating radical socio-economic inequalities. Taken as such, human rights are neither neoliberal nor capitalist, but they might have been instrumentalized into those projects. The inherent emptiness of the rights language has allowed different actors to deploy human rights for interests and purposes contradicting the history and aspirations of the human rights project. For instance, neoliberals have been able to co-opt and redefine human rights to fit them into their own project, recasting trade, market, and capital rights as actual human rights. Since the very start of the neoliberal project in Vienna and Geneva, the fundamental concern was 'the sanctity of capital mobility'. The aim was to demolish state constraints, that is, to gain access to foreign countries as well as - far more importantly - to have 'the right to sell and leave'.128 In more recent times, Ernst-Ulrich Petersmann replied to the mounting questioning on the legitimacy of the WTO by adopting the very human rights language of protesters, conveniently reinterpreting it as to demand more effective protection of economic freedoms and property rights. ${ }^{129}$ The neoliberal reinterpretation of human rights has not always encountered the sort of strenuous resistance that one might expect from the human rights movement. To the contrary, several human rights and humanitarian NGOs have mobilised human rights language to counter Third World demands for economic redistribution. ${ }^{130}$ Indeed, they rejected the idea for which poverty

128 Slobodian, Q., Globalists: The End of Empire and the Birth of Neoliberalism, Harvard University Press, 2018, p. 145 .

129 Ibid., pp. 277-279. See, e.g., Petersmann, E.U., 'The WTO Constitution and Human Rights', Journal of International Economic Law, 3:1 (2000), 19-25; Petersmann, E.U., 'Human Rights and International Economic Law in the $21^{\text {st }}$ Century: The Need to Clarify Their Interrelationship', Journal of International Economic Law, 4:1 (2001), 3-39.

${ }^{130}$ Jessica Whyte has convincingly demonstrated how Liberté sans Frontières (LSF), an organisation established by the French leadership of Médecins sans Frontières (MSF), rejected Third World instances and demands using human rights. Whyte, J, 'Powerless Companions or Fellow Travelers? Human Rights and the Neoliberal 
would be the by-product of the prosperity in the global North, thus placing the responsibility for the plight of the Third World on post-colonial leaders accused of corruption or to oppress their own peoples. This is all the more relevant if one considers the timing: when the New International Economic Order rose to challenge the postcolonial structures of the political economy of the world, human rights ultimately sided with neoliberalism in pushing back. ${ }^{131}$ Considering these historical linkages, it is unsurprising that neoliberals have found human rights a rather useful tool. There are several conceptual connections between human rights and the neoliberal project. Both insist in a relative absoluteness of individual rights against the intrusion and pretenses of governments and states. Human rights offer substantive and procedural guarantees, while also de-politicising particular disputes. Indeed, human rights have somehow espoused the neoliberal logic for which the realm of human emancipation and the only desirable public sphere ought to be found in the market. Moving from this assumption, not only human rights protect private property in fairly strong terms, but they also extend their guarantees to legal persons, that is, companies. ${ }^{132}$ But what does the human rights movement has to say about the increasing privatisation of litigations, that is, the shift from court litigations to private arbitrations or confidential settlements?133 A complete mapping of the way human rights intertwine with neoliberalism is beyond the scope of the present paper. But it is worth stressing that far from being 'indivisible, interdependent, and interconnected', ${ }^{134}$ human rights are often times fragmented and deployed strategically through a selective use and enforcement: some rights are privileged over others; the same rights can be mobilised differently for different projects; and all rights are often interpreted and enforced rather selectively. The end result is that human rights have for some become the 'human rights of capital'.135

\footnotetext{
Assault on Postcolonial Economic Justice ', Radical Philosophy, 2:2 (2018), 13-29.

${ }^{131}$ For instance, human rights helped re-signify 'state-led redistribution as a totalitarian threat to liberty and human rights'. Ibid., p. 26

132 For an overview in the European context, Emberland, M., The Human Rights of Companies: Exploring the Structure of ECHR Protection, Oxford University Press, 2006.

${ }^{133}$ For instance, there has been a growing reliance on compulsory arbitration clauses in labour contracts. With reference to the United States, see, the dedicated issue on the Berkeley Journal of Employment and Labor Law, 35:12 (2014).

134 Vienna Conference on Human Rights, 1993.

135 Cooper, F., 'Afterword: Social Rights and Human Rights in the Time of Decolonization', Humanity, 3 (2012), 473-492 at 487.
} 
(b) A second aspect pertains to a more sociological sphere, that is, the culture and practices of the human rights movement itself. One traditional critique of human rights is that they belong to a specific social class. For instance, Libby Adler has pointed how the LGBT agenda has been seized to reflect the priorities and interests of a relatively welloff group of activists and donors. Indeed, 'access to marriage was at the forefront of the battle for LGBT advancement for more than a decade, along with anti-discrimination protection, [and] hate crimes legislation'. ${ }^{136}$ At the same time, the many socio-economic problems of LGBTQIA people were entirely disregarded, starting with a rampant percentage of homelessness and a higher exposure to health risks. In other words, the priorities and interests of an 'adequately housed and well-nourished class' obscured and neglected the 'pressing needs in the most marginalised sectors of that community'. ${ }^{137} \mathrm{As}$ activism is often dependent on donors, whether private or institutional, a significant part of the work for any human rights organisation has become fund-raising. A fierce competition to attract donations is so that 'donors' can directly or indirectly dictate priorities, conditions, and modalities. Ultimately, this carries the risk of turning human rights into companies that embrace the 'shareholders' mentality. Another common critique to human rights is that they are part of a liberal culture, which places courts and legal litigations at the center stage. But access to courts is not as democratic as it should be and its outcomes impact people differently. Those who have the necessary financial means can not only access courts more easily, but also hire more specialised lawyers. For example, it has been noted that human rights litigations to gain access to medicines or medications favour the middle class ${ }^{138}$ in at least two significant ways. First, whatever litigation primarily promotes the specific interests of those who brought the case in first place. Sometimes, the situation is even more confusing than that: law firms offer to take on strategic litigations pro bono, while interest groups can finance court cases when they believe it could advance their agenda. Secondly, individual human rights cases can

\footnotetext{
136 Adler, L., Gay Priori: A Queer Critical Legal Studies Approach to Law Reform, Duke University Press, p. 2.

137 Adler, Gay Priori, pp. 2-3.

138 See, e.g., Kapczynski, 'The Right to Medicines in an Age of Neoliberalism'; Ferraz, O.L.M., 'The Right to Health in the Courts of Brazil: Worsening Health Inequities?', Health and Human Rights ,11:2 (2009), 33-45; Ferraz, O.L.M., 'Moving the Debate Forward in Right to Health Litigation', Health and Human Rights, 18:2 (2016), 265-268; Brinks, D.M. \& Gauri, V., “A New Policy Landscape: Legalizing Social and Economic Rights in the Developing World", in Gauri and Brinks (eds.), Courting Social Justice: Judicial Enforcement of Social and Economic Rights in the Developing World, Cambridge University Press, 2008.
} 
significantly erode the ability of the state to provide public health services because litigations as such as well as successful litigants who are awarded compensations erode the budget, which translate into a cut to services that generally tend to bear more importance to the poor. ${ }^{139}$ Therefore, although human rights litigations are usually presented as pursuing a general public or collective interest, the case of access to medicine proves that this is not always the case. Generally speaking, the human rights movement and its activism are both diverse and disperse. ${ }^{140} \mathrm{~A}$ significant part of the human rights activism intervenes in response to situated crises that do not receive adequate institutional responses, whether locally or internationally. As the human rights movement becomes increasingly specialised and promotes legal cases focusing on narrow points, there is indeed a disconnection between the aim of specific instances and the broader picture. Human rights interventions turn into technical matters, embedding human rights in the culture of expertise. Thus, human rights bend to the inner logic of expertise, thinking like it: they seek specialisation, efficiency, managerialism, and so forth. Therefore, although speaking of root causes of human rights violations have become somewhat fashionable within the human rights movement, there is often little engagement with the larger framework within which those conditions are systematically reproduced'. ${ }^{141}$ As human rights activism and battles become more bureaucratic, addressing a given human rights violation may ultimately obfuscate the bigger picture, that is, the conditions of possibility for human rights violations. In turning human rights battles 'technical', even situations like world hunger are made to appear as natural phenomena inscribed into a history of progress instead of the direct outcome of a human-created economic system.

Human rights suffer from two problems, namely helplessness and complicity. Human rights are instrumentalized, whereas the movement seem to share, at least in part, certain

\footnotetext{
139 Reports show that 'litigants frequently obtain expensive and even ineffective medicines that are not recommended by or included in the national formularies that determine what public and private insurers must provide'. Nonetheless, 'courts [can] demand that medicines be provided regardless of their cost, but health budgets are necessarily limited'. Kapczynski, 'The Right to Medicines in an Age of Neoliberalism', p. 78 .

${ }^{140}$ This is both a point of strength and weakness, as noted by Simmons, B.A., 'The Future of the Human Rights Movement', Ethics \& International Affairs, 28:2 (2014), 183-196.

${ }^{141}$ Marks S., 'Human Rights and Root Causes', Modern Law Review, 74:1 (2011), $57-78$ at 71.
} 
mind-sets and practices with neoliberal capitalism. As a consequence, human rights contribute to shape a largely de-politicised world dominated by formal and functional expertise, a world of struggles in which private interests shape the public discourse and institutions to achieve dominance. ${ }^{142}$ Hence, instead of being the voice of the voiceless, human rights risk becoming part of the toolbox of the powerful to assert and advance their projects and interests. As economic and material interests prevail over the effective protection of people, the peril for the human rights movement is to become, more or less unawarely, the guardians of that unequal political economy of the world that it should instead fight. For these reasons, we do not believe that simply doubling down on the existing human rights project with the help of 'familiar strategies' enough. Rather, we need a much more radical approach to human rights.

\section{Reflections}

In the human rights movement, the rise of populist movements has ignited a sense of crisis. The once liberal, democratic, and internationalist Western world is slowly drifting towards more or less marked forms of authoritarianism. In the face of this historical phase, Philip Alston has intervened to defend the merits of the human rights project and double down on it. He has identified a series of problems and advanced a strategy for confronting what he defines as 'unprecedented challenges'. However, the present paper has argued two main things: first, the struggle Alston identifies against populism might turn out misleading; second, the Alston's proposed strategy may prove either ineffective or counter-productive. Indeed, we have aimed at expanding the existing conversation to show how Alston's doubling down on a 'familiar strategy' may fall short from tackling socio-economic inequalities because of some deeper problems that affect the human rights regime and movement.

The human rights project 'has never been a consensus project. It has almost always been a product of struggle'. ${ }^{143}$ But not all struggles bear the same weight. In Alston's view, the

\footnotetext{
142 Kennedy, D., A World of Struggle: How Power, Law, and Expertise Shape Global Political Economy, Princeton University Press, 2016.

${ }^{143}$ Alston, 'The Populist Challenge', p. 3.
} 
challenge to face is about populism. However, populism is only a tactic that even the human rights movement itself has occasionally made use of. In contrast, the struggle is between human rights and the re-emerging forms of nationalism, which - in all their differences seem equally regressive both psychologically and materially. That is to say, they bring a reflux of xenophobia with an obsession for security, both of which lead to the dismantling of welfare provisions. While the nationalism of the late $19^{\text {th }}$ and early $20^{\text {th }}$ centuries had some vague elements of solidarity, contemporary nationalism is solely identitarian. Nationalist movements leverage the discontent for globalisation and the range of inequalities it brought with it. But what they have to offer is far from their actual rhetoric: most nationalisms have so far privileged those very elites they were meant to battle.

The first great challenge for the human rights movement is therefore that of locating and identifying the actual struggle. Today, there are ghostly forms of dominance that mainstream versions of human rights are unequipped to challenge. A traditional logic of 'naming and shaming' can only superficially - and thus insufficiently - scratch a system of dominance largely built upon and throughout forms of private law. ${ }^{144}$ Engaging with private law also means that power is hardly visible and centralised. Geneva and New York, for how relevant, cannot become the sole focus of action. Hence, the movement ought to reach 'the ends of the network, where people are using human rights promiscuously as they build power locally'. ${ }^{145}$ In other words, the effects of an increasingly sophisticated and private dominance are felt first and foremost in local and apparently marginal instances.

Human rights have already won many battles. It is thus understandable how one could imagine confronting today's challenges of populism and inequalities with 'the recipe that we have developed for civil and political rights promotion', that is, recognition, institutionalisation, and accountability - just applied to economic and social rights.

\footnotetext{
144 See, e.g., Watt, H., 'Competition or Confluence? Private International Law and Human Rights in Global Governance', Revue Internationale De Droit Économique, 27:1-2 (2003), 59-78; Watt, H., "Theorizing Private International Law", in Orford, A. and Hoffman, F. (eds.), The Oxford Handbook of the Theory of International Law, Oxford University Press, 2016, pp. 862-882; Watt, H., 'When Societal Constitutionalism Encounters Private International Law: Of Pluralism, Distribution, and "Chronotopes"', Journal of Law and Society, 45:1 (2018), 185203.

145 Kapczynski, A., 'What Comes after Not Enough?', Law and Political Economy Blog, available at https://lpeblog.org/2018/06/11/ what-comes-after-not-enough/ (last access, August $5^{\text {th }}, 2019$ )
} 
However, the human rights movement has first to sort out its complicity with that very system it aims to transform. There is need for a human rights movement 'that sees and reveals rather than denies connections between rights and markets'. ${ }^{146}$ Human rights have to come to terms with their recent past, their relation to markets, as well as their own power. That is, the embeddedness of human rights within the political economy of the world and, ${ }^{147}$ as Jessica Whyte has noted, the complicity of human rights with neoliberalism. Without doing so, the danger is to repeat mistakes and be ineffective at best or damaging at worst. For instance, there is the relative risk to create a new group of international experts that will ultimately establish de-politicised bureaucratic processes and vocabularies, exploiting struggles rather than fighting them. ${ }^{148}$ The future of human rights and their movement cannot be one of further de-politicisation.

The struggle against nationalist movements is ultimately one of narrative and imaginary. In this battle, human rights must be able to win back the streets, politics and media and be able to work with different actors from environmentalists to labour unions which are more equipped to deal with some of the issues that have contributed to the current situation. ${ }^{149}$ Although Alston laments that academic critiques of human rights serve little purpose other than infusing a sense of hopelessness into students, we believe it is through critique that new narratives can emerge to regenerate the human rights enterprise. Part of the task is historiographical, ${ }^{150}$ for the neoliberal hijacking of human rights has foreclosed alternative and potentially more powerful traditions that should be rediscovered and revived. ${ }^{151}$

\footnotetext{
146 Kapczynski, 'What Comes after Not Enough?'.

147 Manfredi, Z., 'Recent Histories and Uncertain Futures', Qui Parle, 22:1, 2013, 3-32, p. 5: 'human rights are not only inefficacious tools but also collaborators in a pernicious politics of inequality and domination'.

148 Koskenniemi, 'Human Rights Mainstreaming as a Strategy for Institutional Power'.

149 Goldston, J.A., 'A Wake-up Call for Human Rights', Project Syndicate, available at https://www.projectsyndicate.org/commentary/human-rights-groups-criticism-populism-by-james-a-goldston-2019-08 (last access on August 21 $\left.{ }^{\text {st }}, 2019\right)$.

150 There has already been a historiographical turn in the field of human rights. See, Moyn, S., The Last Utopia: Human Rights in History, The Belknap Press of Harvard University Press, 2010; Moyn, S., Human Rights and the Uses of History, Verso, 2014; Alston, P., 'Does the Past Matter? On the Origins of Human Rights', Harvard Law Review, 126, 2012-13, 2043-2081; Slotte, P. and Halme-Tuomisaari, M. (eds.), Revisiting the Origins of Human Rights, Cambridge University Press, 2015.

${ }^{151}$ For example, see, Marks, S., A False Tree of Liberty: Human Rights in Radical Thought, Oxford University Press 2019. Marks delves into rights discussion in the $16^{\text {th }}$ to $18^{\text {th }}$ century England to unearth a forgotten tradition of human rights thought. Contrasting the views of forsaken thinkers such as Thomas Spence to the eventually more successful tradition of rights, which has been used primarily to support property rights and other civil and political rights, Marks suggests that there is possibility to use the concept of human rights in a more radical way. Indeed, as Spence conceived them, the rights of man were about revealing and transforming conditions
} 
Historically, the forgotten foundational principle of not solely human rights, but also of nations, is less that of formal equality than that of solidarity. Indeed, the debate about and around formal versus absolute equality is inevitably inconclusive: full material equality is impossible (for there can never be a condition in which everyone is equal to everybody else in everything) while formal equality is insufficient. Just like freedom and equality cannot be taken apart, 152 so do equality and solidarity. For formal equality to be effective, it has to come with solidarity ties based not a mere sufficiency but on mutual insurance and redistribution. The French Revolutionaries proclaimed 'freedom, equality, and brotherhood', the latter being a demand for material solidarity among the members of the same community. At the same time, the idea of nation, as it emerged throughout the $19^{\text {th }}$ and $20^{\text {th }}$ centuries, was an imagined community that entailed a fundamental principle of solidarity among its members, a solidarity that entailed a public form of mutual insurance.

Contemporary forms of nationalism replace material solidarity with empty narratives about 'crippled' identities, that is, national identities that can only stand in opposition to some 'enemy' 153 they instrumentalize migration to antagonize the 'other' and create a fictitious sense of community under attack, to denigrate global solidarity while also cutting back on those material forms of national solidarity known as welfare, to marginalise the role of the state in providing for its less fortunate members at the advantage of private forms of philanthropy. Therefore, one way the human rights movement can take over the new wave of nationalism is to offer more credible and tangible answers: against the erosion of social bonds and state welfare, human rights can revive the forgotten principle of collective solidarity both within and beyond national borders.

\footnotetext{
of oppression, and about subsistence, as opposed to property and enclosure. While universal, they were rights of particular people in particular places, focused on articulating social-systemic injustice and addressing the gap between our shared humanity and real inequalities.

152 Balibar, E., 'The Proposition of Equaliberty', in Equaliberty, Duke University Press, 2014, pp. 67-98.

153 The binomial 'friend-and-enemy' revives the unhappy characterization of the political given in Schmitt, C., The Concept of the Political, Chicago University Press, 2007, p. 26.
} 